
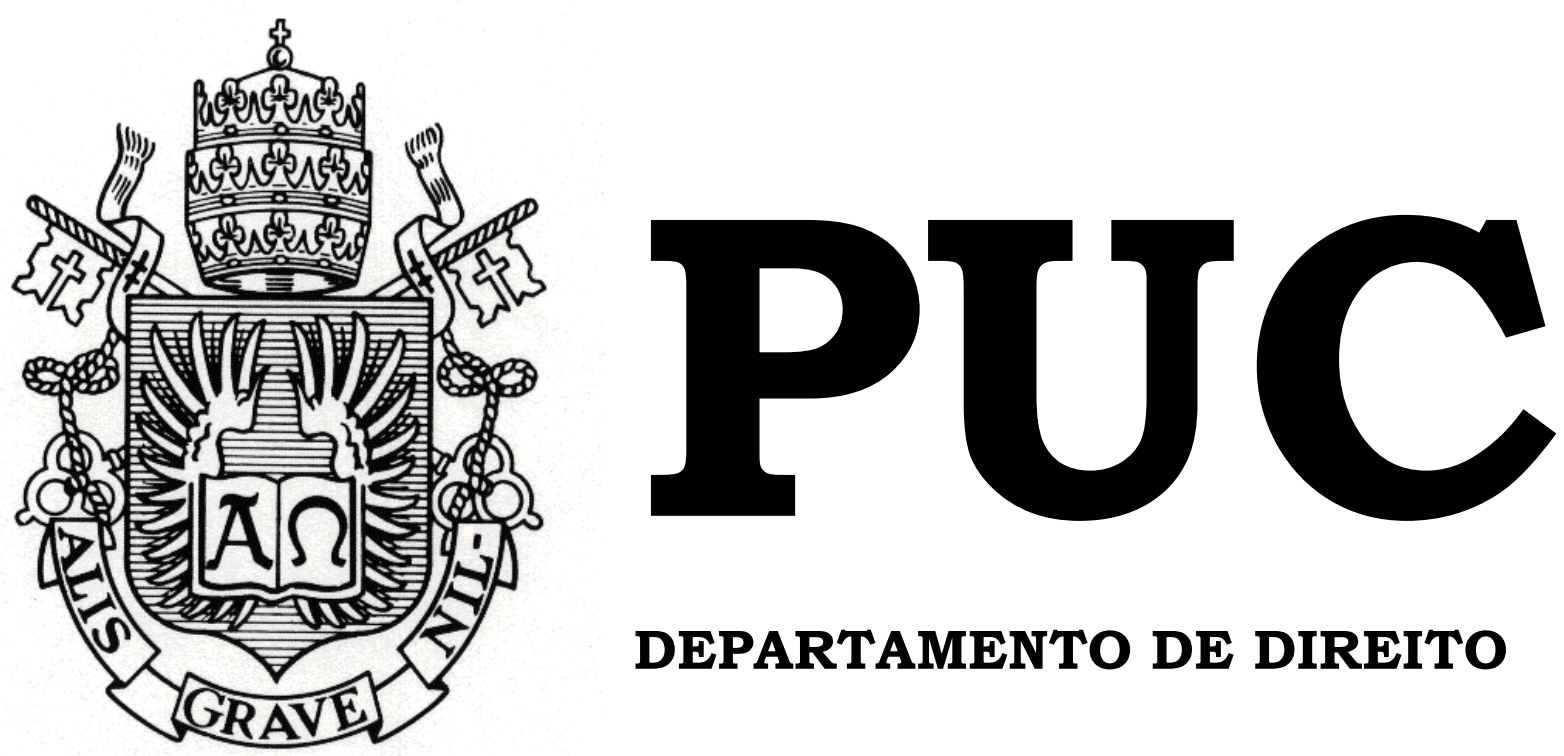

DEPARTAMENTO DE DIREITO

\title{
TRABALHO ESCRAVO NO BRASIL: DO CASO JOSÉ PEREIRA AO CASO FAZENDA BRASIL VERDE
}

Por

PRISCILA VAZQUEZ DIAS

ORIENTADOR: ANTONIO PELE

2016.2

PONTIFÍCIA UNIVERSIDADE CATÓLICA DO RIO DE JANEIRO

RUA MARQUÊS DE SÃO VICENTE, 225 - CEP 22451-900

RIO DE JANEIRO - BRASIL 


\section{TRABALHO ESCRAVO NO BRASIL: DO CASO JOSÉ PEREIRA AO CASO FAZENDA BRASIL VERDE}

por

\section{PRISCILA VAZQUEZ DIAS}

Monografia apresentada ao

Departamento de Direito da

Pontifícia Universidade Católica do Rio de Janeiro (PUC-Rio) para a obtenção do Título de Bacharel em Direito.

Orientador: Antonio Pele 


\section{AGRADECIMENTOS}

À Deus, por ser amor.

Ao meu avô Raymundo, meu eterno herói e maior fonte de saudade.

Ao Gabriel, por ser meu sorriso companheiro em todos os mais diversos e adversos momentos.

Aos meus queridos pais, Madison e Simone, pelo amor incondicional. Sem vocês nenhuma das minhas mais memoráveis conquistas e alegrias seriam possíveis.

À minha irmã Amanda, por todo o amor, paciência e compreensão.

À minha avó Pura, por todo o carinho, abdicação e apoio moral durante as madrugadas de estudo.

À minha avó Gilvane, pela arte e delicadeza.

Ao Núcleo de Direitos Humanos da PUC-Rio e ao Núcleo de Defesa dos Direitos Humanos da Defensoria Pública, por me fazerem acreditar que o caminho para os direitos humanos é longo, mas possível.

Ao meu orientador, o Professor Antonio Pele, por toda a atenção, paciência e sabedoria ao longo da minha trajetória para além da monografia.

Ao Lucas e ao José, por tornarem a jornada "puquiana” sempre agradável.

Às minhas amigas Yasmin, Duda e Gabryella, pela amizade que supera qualquer tempo e qualquer distância. 


\section{RESUMO}

$\mathrm{O}$ presente estudo tem por objetivo analisar o enfrentamento ao trabalho escravo contemporâneo rural no Brasil, a partir do acordo de Solução Amistosa no Caso José Pereira realizado no seio da Comissão Interamericana de Direitos Humanos em 2003, considerado um importante marco para o enfrentamento desse grande problema. Para tanto, descreveremos os fatos do caso e as cláusulas acordadas. Seguiremos estudando o cumprimento desse acordo e elencando as principais medidas adotadas pelo Brasil para enfrentar os desafios relacionados ao contexto de trabalho escravo contemporâneo. Em seguida, analisaremos as ameaças às medidas alcançadas e os motivos que levaram a Comissão a submeter outro caso contra o Brasil à jurisdição da Corte Interamericana - o Caso Brasil Verde -, cuja temática central também é o trabalho escravo rural. Por fim, elucidaremos as expectativas do Estado, da Comissão e dos peticionários quanto à futura sentença da Corte no Caso Fazenda Brasil Verde e faremos uma análise crítica sobre tais expectativas, diante dos desafios ao enfrentamento ao trabalho escravo contemporâneo rural no Brasil.

Palavras-Chave: Trabalho escravo; Sistema Interamericano de Proteção aos Direitos Humanos; Comissão Interamericana de Direitos Humanos; Solução Amistosa Caso José Pereira; Caso Fazenda Brasil Verde 
INTRODUÇÃ

CAPÍTULO 1 - O SISTEMA INTERAMERICANO DE DIREITOS

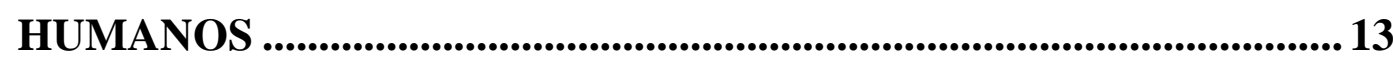

1.1. A formação do sistema interamericano …………………………....... 13

1.2. Atuação dos órgãos do sistema interamericano ............................... 16

1.2.1. A Comissão Interamericana de Direitos Humanos ........................ 16

1.2.2. A Corte Interamericana de Direitos Humanos ............................... 19

CAPÍTULO 2 - SOLUÇÃO AMISTOSA NO CASO JOSÉ PEREIRA

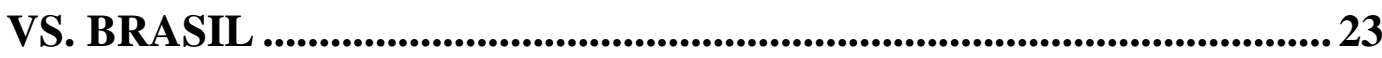

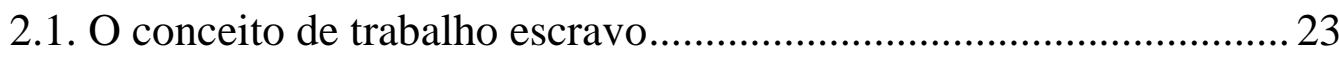

2.2. Breve contextualização do trabalho escravo contemporâneo no Brasil

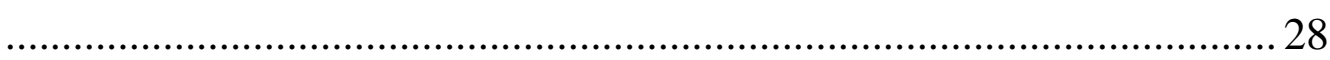

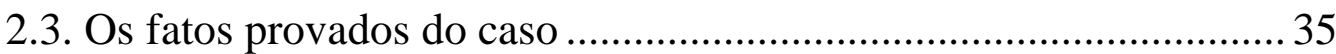

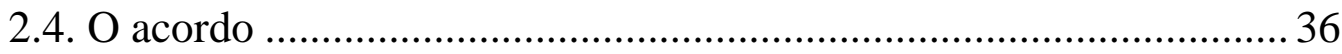

2.4.1. Medidas de Reconhecimento, Julgamento e Reparação ................. 38

2.4.2. Medidas de Prevenção ....................................................................... 40

2.4.3. Mecanismo de Seguimento......................................................... 43

CAPÍTULO 3. AVANÇOS E RETROCESSOS POLÍticos E JURÍDICOS POSTERIORES AO ACORDO......................................... 45

3.1. Medidas Alcançadas Pelo Brasil ...................................................... 46

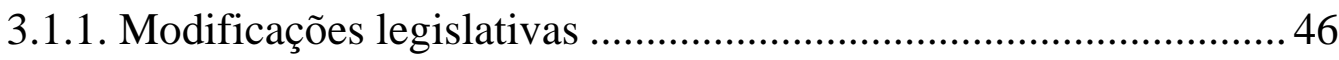

3.1.2. Medidas de Repressão e Prevenção................................................ 52

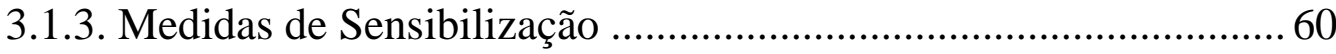

3.2. Ameaças ao Enfrentamento ao Trabalho Escravo Contemporâneo. 62

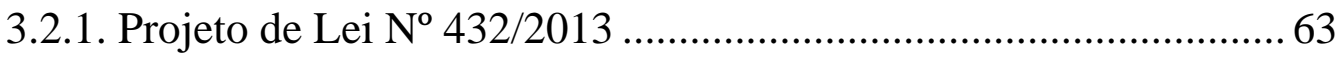

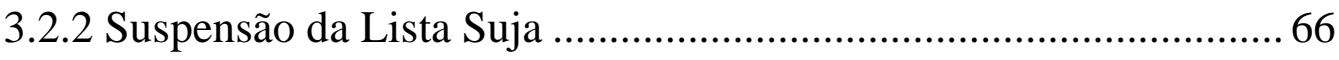

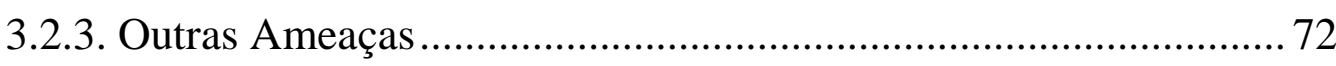

CAPÍTULO 4 - O CASO FAZENDA BRASIL VERDE VS. BRASIL 74 
4.1 Os Fatos do Caso e as Considerações da CIDH ................................. 75

4.1.1. Os fatos provados do caso e as medidas adotadas pelo Estado..... 77

4.1.2. Considerações da Comissão Interamericana …………………….... 86

4.2. Expectativas em relação à Sentença .................................................... 91

4.2.1. Considerações dos representantes das vítimas ............................... 92

4.2.2. Considerações do representante do Estado .................................... 94

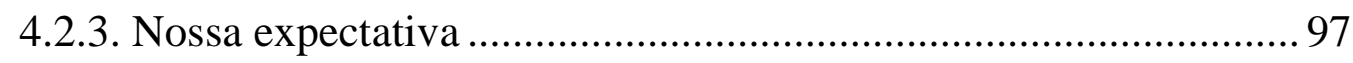

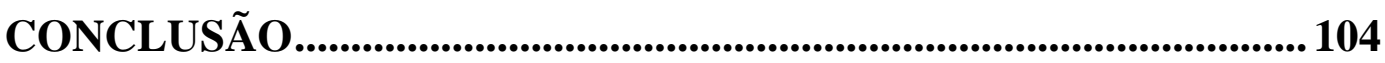

REFERÊNCIAS BIBLIOGRÁFICAS ..................................................110 


\section{LISTA DE ABREVIATURAS}

ABRAINC - Associação Brasileira de Incorporadoras Imobiliárias

ADIN - Ação Direta de Inconstitucionalidade

CADH - Convenção Americana de Direitos Humanos

CIDH - Comissão Interamericana de Direitos Humanos

CEJIL - Center for Justice and International Law

CF ou CRFB - Constituição Federal

CLT - Consolidação das Leis Trabalhistas Corte IDH - Corte Interamericana de Direitos Humanos

CONATRAE - Comissão Nacional de Erradicação do Trabalho Escravo

$\mathrm{CP}$ - Código Penal

CPT - Comissão Pastoral da Terra

CCJC - Comissão de Constituição e Justiça e Cidadania

CTASP - Comissão de Trabalho, de Administração e Serviço Público

DTESD - Divisão de Repressão ao Trabalho Escravo e de Segurança dos

Dignitários

DRT - Delegacia Regional do Trabalho

EC - Emenda Constitucional

GEFM - Grupo Especial de Fiscalização Móvel

LAI - Lei de Acesso à Informação

MTE - Ministério do Trabalho e Emprego

MPT - Ministério Público do Trabalho

OEA - Organização dos Estados Americanos

ONU - Organização das Nações Unidas

OIT - Organização Internacional do Trabalho

PL - Projeto de Lei

PEC - Projeto de Emenda Constitucional

SIDH - Sistema Interamericano de Direitos Humanos

STF - Supremo Tribunal Federal 


\section{O OUTRO BRASIL QUE VEM AÍ}

"Eu ouço as vozes

eu vejo as cores

eu sinto os passos

de outro Brasil que vem aí

mais tropical

mais fraternal

mais brasileiro.

O mapa desse Brasil em vez das

cores dos Estados

terá as cores das produções e dos

trabalhos.

Os homens desse Brasil em vez das

cores das três raças

terão as cores das profissões $e$

regiões.

As mulheres do Brasil em vez das

cores boreais

terão as cores variamente tropicais.

Todo brasileiro poderá dizer: é

assim que eu quero o Brasil,

todo brasileiro e não apenas o

bacharel ou o doutor

o preto, o pardo, o roxo e não

apenas o branco e o semibranco.

Qualquer brasileiro poderá

governar esse Brasil

lenhador

lavrador

pescador

vaqueiro

marinheiro

funileiro

carpinteiro

contanto que seja digno do governo do Brasil

que tenha olhos para ver pelo Brasil, ouvidos para ouvir pelo Brasil

coragem de morrer pelo Brasil

ânimo de viver pelo Brasil

mãos para agir pelo Brasil

mãos de escultor que saibam lidar

com o barro forte e novo dos Brasis

mãos de engenheiro que lidem com

ingresias e tratores europeus $e$

norte-americanos a serviço do Brasil mãos sem anéis (que os anéis não deixam o homem criar nem trabalhar).

mãos livres

mãos criadoras

mãos fraternais de todas as cores mãos desiguais que trabalham por um Brasil sem Azeredos,

sem Irineus

sem Maurícios de Lacerda.

Sem mãos de jogadores

nem de especuladores nem de mistificadores.

Mãos todas de trabalhadores, pretas, brancas, pardas, roxas, morenas,

de artistas

de escritores

de operários

de lavradores

de pastores

(...)

de mestres guiando aprendizes

de irmãos ajudando irmãos mais

moços

(...)

Mãos brasileiras

brancas, morenas, pretas, pardas,

roxas

tropicais

sindicais

fraternais.

Eu ouço as vozes

eu vejo as cores

eu sinto os passos

desse Brasil que vem aí”.

( $O$ outro Brasil que vem aí. Gilberto Freyre, 1926) ${ }^{1}$

\footnotetext{
${ }^{1}$ FREYRE, Gilberto. Casa-grande \& Senzala.
} $48^{\mathrm{a}}$ ed. Recife: Global Editora, 2003. 


\section{INTRODUÇÃO}

No Brasil, a escravidão remonta ao século XVI, época em que o país era colônia portuguesa ${ }^{2}$. Inicialmente, os indígenas foram escravizados e, posteriormente, os escravos passaram a ser pessoas provenientes do continente africano. O movimento abolicionista iniciou-se em 1850 e em 1888 a escravidão foi legalmente erradicada. Contudo, os ex-escravos não receberam qualquer tipo de subsídio e amparo para se reintegrarem na sociedade e viram-se obrigados a se submeter ao campo laboral de menor prestígio social. Adicionalmente, apesar da existência de uma Lei de Terras que permitia ao Estado a venda de terras "não ocupadas" a classes sociais desfavorecidas, os ex-escravos não tinham condições de obtê-las devido ao custo elevado a elas atribuído. A fim de sobreviver, a maioria desses exescravos se viram obrigados a submeter-se a trabalhos com salários irrisórios nos grandes latifúndios dos fazendeiros. A exploração laboral dessas pessoas desencadeou uma reconfiguração do trabalho escravo ${ }^{3}$.

A partir do início do século XX, o Brasil teve um desenvolvimento industrial e econômico forte devido à exploração da floresta amazônica, resultando na atração de grande quantidade de trabalhadores à região. A industrialização intensificou-se e se expandiu o fenômeno conhecido como grilagem, que consiste na posse ilegal e adjudicação descontrolada das terras públicas, propiciando a consolidação da exploração de mão-de-obra escrava em fazendas de amplas extensões de terra, muitas vezes de propriedade de empresas privadas ou familiares. Segundo a OIT, nesse contexto a autoridade estatal estava ausente da região norte. Como

\footnotetext{
${ }^{2}$ AGUIRRE, Carlos et al.. La abolición de la esclavitud em hispanoamérica y Brasil. Nuevos aportes y debates historiográficos. p. 66. Fundación Ignacio Larramendi. Disponível em: <http://www.larramendi.es/i18n/catalogo_imagenes/grupo.cmd?path=1000211>. Acesso em: 24 out. 2016.

${ }^{3}$ OIT. Combatendo o trabalho escravo contemporâneo: o exemplo do Brasil, 2010. p. 113.
} 
consequência, as autoridades regionais foram convertidas em aliadas dos latifundiários ${ }^{4}$.

A OIT recebeu as primeiras denúncias de trabalho escravo contemporâneo no Brasil em meados dos anos setenta e nos anos oitenta a organização passou a acompanhar a situação com maior atenção. Ainda segundo a OIT, em 1993 foram denunciados aproximadamente 20 mil casos de trabalho escravo. Contudo, em 1995, a Comissão Interamericana de Direitos Humanos (doravante CIDH) realizou uma visita in loco ao Brasil. Nessa visita a CIDH recebeu a informação de que no ano de 1993 existiriam, na verdade, aproximadamente 60 mil trabalhadores submetidos a tais condições no país, ou seja, três vezes mais do que a quantidade de denúncias recebidas pela OIT $^{5}$.

Em vista da constatação da grave situação de exploração de trabalho escravo no Brasil, em 1999 a CIDH aprovou um relatório de admissibilidade e mérito sobre o Caso José Pereira vs. Brasil, primeiro caso cujo objeto central era o trabalho escravo no Sistema Interamericano de Direitos Humanos. Em 2003, o Estado brasileiro assinou um acordo de Solução Amistosa com os peticionários no caso José Pereira, reconhecendo a responsabilidade internacional pelas denúncias feitas e comprometendo-se a enfrentar o trabalho escravo no país 6 . É importante mencionar que entramos em contato com os peticionários desse caso e solicitamos informações acerca do cumprimento do acordo por parte do Brasil, mas os mesmos responderam que deixaram de acompanhar o caso há cinco anos e que não teriam disponibilidade para procurar os relatórios de acompanhamento enviados à CIDH anos antes.

O Brasil conseguiu conquistar, ainda que tardiamente e sob forte pressão internacional, grandes avanços no que tange ao enfrentamento ao

\footnotetext{
${ }^{4}$ OIT. Combatendo o trabalho escravo contemporâneo: o exemplo do Brasil, 2010, p. 62. SHAHINIAN, 2010, p. 25.

${ }^{5}$ Relatório n¹69/11, Caso 12.066 Admissibilidade e Mérito: Fazenda Brasil Verde vs. Brasil. OEA/Ser/L/V/II.143. Doc. 53. 3 de novembro de 2011. Parágrafos 65 e 66.

${ }^{6}$ Informe no 95/03. Petición 11.289. Solução Amistosa. José Pereira e Brasil.
} 
trabalho escravo, como a criação da Comissão Nacional de Erradicação do Trabalho Escravo (CONATRAE) e a aprovação da Emenda Constitucional $\mathrm{n}^{\circ}$ 81. Contudo, é importante se ter em mente que os traços arcaicos de uma cultura estruturalmente escravagista ainda permanecem enraizados em nossa sociedade ${ }^{7}$, de modo que a atuação da Comissão Interamericana de Direitos Humanos e os programas de enfrentamento ao trabalho escravo contemporâneo adotados pelo Brasil, devem ser analisados à luz desse solo histórico.

Recentemente, os avanços - grandes, porém não suficientes estagnaram e alguns dos mecanismos mais importantes adotados pelo Brasil sofreram retrocessos, como a suspensão da Lista Suja por uma medida liminar do STF e a tramitação de projeto de lei para alterar o conceito de trabalho escravo previsto no Código Penal, de modo a restringi-lo.

Por tais motivos, a CIDH passou a pressionar o Brasil para que este cumprisse suas recomendações no relatório de admissibilidade e mérito de outro caso envolvendo trabalho escravo no Brasil, o Caso Fazenda Brasil Verde vs. Brasil. Contudo, o país não mostrou interesse em celebrar outra solução amistosa nos moldes do caso José Pereira ou de cumprir as recomendações feitas pela CIDH. Diante dessa situação, em 4 de março de 2015 a CIDH enviou o mencionado caso para a Corte IDH $^{8}$, a qual terá a oportunidade de julgar, pela primeira vez, um caso cujo tema central é o trabalho escravo contemporâneo. A perspectiva de um posicionamento da corte sobre o tema evidencia a importância de se construir mecanismos mais eficazes no enfrentamento à escravidão contemporânea, bem como na construção de um diálogo que marque um novo paradigma, e é nesse sentido que se justifica o presente trabalho.

\footnotetext{
${ }^{7}$ SOARES, Marcela. Como Erradicar o Trabalho Escravo no Brasil? Notas a Propósito do Relatório da ONU. Brasiliana - Journal for Brazilian Studies. Vol. 2, n. 2 (Nov. 2013). ISSN 2245-4373.

${ }^{8}$ Informações obtidas por meio do documento em que a Comissão submete o Caso Fazenda Brasil Verde vs. Brasil à jurisdição da Corte, datado de 4 de março de 2015. Disponível em: <https://www.oas.org/es/cidh/decisiones/corte/2015/12066NdeResPT.pdf〉. Acesso em: 15 nov. 2016.
} 
Dentro desse contexto, o objetivo da presente monografia será analisar o enfrentamento ao trabalho escravo contemporâneo rural no Brasil, a partir de um grande marco, que foi o do acordo de Solução Amistosa no Caso José Pereira. Essa análise será feita a partir do estudo do caso, dos avanços e retrocessos da situação de exploração de trabalho escravo rural no Brasil após a celebração do acordo, e das expectativas quanto ao iminente julgamento do Caso Brasil Verde vs. Brasil.

Em busca de preencher o objeto do trabalho de forma mais completa, adotaremos como método de pesquisa a descrição dos fatos desses dois casos, das cláusulas da Solução Amistosa no Caso José Pereira e das considerações adotadas pela Comissão Interamericana de Direitos Humanos em seu Relatório de Admissibilidade e Mérito no Caso Fazenda Brasil Verde. Além disso, elencaremos as principais medidas adotadas pelo Brasil para cumprir o acordo de Solução Amistosa e enfrentar o trabalho escravo contemporâneo. Em seguida, analisaremos algumas ameaças à evolução desse enfrentamento ao trabalho escravo, bem como demonstraremos as razões para a Comissão submeter o Caso Fazenda Brasil Verde à Corte Interamericana. Por fim, analisaremos criticamente as expectativas quanto à Sentença a ser proferida pela Corte.

Quanto à estrutura, o trabalho está dividido em quatro capítulos. No primeiro deles apresentaremos o Sistema Interamericano de Proteção aos Direitos Humanos e os papeis desempenhados pela Comissão e pela Corte. Como o presente trabalho apresenta um acordo de solução amistosa no seio da Comissão e a submissão de um caso pela Comissão à Corte, é importante que o leitor entenda o funcionamento, o âmbito e a limitação da atuação de cada um desses dois órgãos.

No segundo capítulo, explicaremos brevemente o conceito de trabalho escravo utilizado atualmente, em especial pela Organização Internacional do Trabalho. Nesse capítulo também apresentaremos um panorama geral do contexto em que se insere o trabalho escravo 
contemporâneo no Brasil. Por fim, descreveremos os fatos do Caso José Pereira e as cláusulas do acordo de Solução Amistosa alcançado pelo Estado brasileiro e os representantes da vítima do caso.

No terceiro capítulo elencaremos as principais medidas adotadas pelo Brasil para cumprir com o acordo de Solução Amistosa e analisaremos algumas das principais ameaças diante do enfrentamento ao trabalho escravo contemporâneo.

Por fim, no quarto capítulo descreveremos os fatos do Caso Fazenda Brasil Verde e as considerações feitas pela Comissão Interamericana ao submeter o caso à Corte. Para finalizar o último capítulo desse trabalho, analisaremos as expectativas quanto à Sentença que deve ser proferida pela Corte ainda no ano de 2016, e o que consideramos como os maiores desafios a serem enfrentados pelo Brasil a partir desse julgamento.

É importante destacar que as análises dos fatos desses dois casos foram baseadas nos documentos disponíveis pela CIDH. Em relação às medidas tomadas pelo Brasil para o enfrentamento ao trabalho escravo contemporâneo, os principais materiais utilizados foram relatórios oficiais de organizações internacionais, de organizações não-governamentais que atuam na área e documentos oficiais do Ministério do Trabalho e Emprego, bem como foi realizado acompanhamento de trâmite legislativo nos sites da Câmara dos Deputados e do Senado.

Antes de prosseguir com o texto, é importante informar aos leitores e leitoras que a sentença do Caso Fazenda Brasil Verde foi publicada no dia 15 de dezembro de 2016, após a conclusão e entrega do presente trabalho, um dia antes da defesa do mesmo perante a banca. Por tal motivo, não foi possível analisarmos a sentença. Contudo, como abordamos no último capítulo as expectativas quanto à mesma, na conclusão traçaremos alguns breves comentários sobre se estas foram atendidas. 


\section{CAPÍTULO 1 - O SISTEMA INTERAMERICANO DE DIREITOS HUMANOS}

No contexto histórico vivenciado pelo Brasil, o Sistema Interamericano de proteção aos Direitos Humanos (doravante SIDH ou Sistema Interamericano) está começando a desenvolver um papel relevante, apesar de recente, no combate ao trabalho escravo contemporâneo.

O presente capítulo tem o objetivo de apresentar o Sistema Interamericano para que o leitor tenha uma visão clara dos mais importantes mecanismos internacionais e do funcionamento dos órgãos que compõem esse sistema, permitindo uma melhor compreensão acerca dos casos que serão analisados nesse trabalho.

Como o nosso principal escopo não é discorrer profundamente sobre esse sistema regional de proteção aos direitos humanos, este capítulo será abordado de forma resumida. Para melhor compreensão, ele está dividido em dois tópicos. No primeiro será abordada a formação do sistema interamericano (tópico 1.1) e no segundo será explicado o âmbito de atuação de cada um dos dois órgãos que compõem esse sistema de proteção, quais sejam, a Comissão e a Corte (tópico 1.2).

\subsection{A formação do sistema interamericano}

O sistema internacional de proteção aos Direitos Humanos pode ser dividido em dois grupos de atuação. Por um lado, existe o sistema global, formado por instrumentos internacionais e órgãos burocráticos conduzidos pela Organização das Nações Unidas. De outro lado, existem os sistemas regionais de proteção, cujo objetivo é internacionalizar os direitos humanos no plano regional, atendendo às particularidades de cada área do globo. Atualmente, temos três grandes sistemas: o Europeu, o Africano e o 
Americano. Para atender aos objetivos desse trabalho, apenas o sistema regional da América será analisado.

O SIDH é composto por quatro principais instrumentos: a Carta dos Estados Americanos (1948), a Declaração Americana dos Direitos e Deveres do Homem (1948); a Convenção Americana sobre Direitos Humanos (1969) - também conhecida como Pacto de San José da Costa Rica -, e o Protocolo Adicional à Convenção Americana em Matéria de Direitos Econômicos, Sociais e Culturais (1988) - chamado também de Protocolo de San Salvador? .

O sistema regional americano se originou com a proclamação da Carta da Organização dos Estados Americanos ${ }^{10}$ (Carta de Bogotá) de 1948, aprovada na $9^{\mathrm{a}}$ Conferência Internacional dos Estados Americanos. Nessa mesma conferência, também foi celebrada a Declaração Americana dos Direitos e Deveres do Homem (doravante "Declaração Americana"). A Declaração formou a primeira base normativa de proteção aos direitos humanos de caráter geral no sistema e continua sendo um instrumento de importância e expressão regional, especialmente para os Estados que não são parte da Convenção Americana ${ }^{11}$.

A Declaração se destacou de outros instrumentos internacionais de direitos humanos pois não definiu apenas os direitos, mas os deveres dos cidadãos $^{12}$. Apesar desse destaque, a Declaração não é considerada um tratado internacional, mas constitui fonte de obrigação para os Estados

\footnotetext{
${ }^{9}$ MAZZUOLI, Valerio de Oliveira. Curso de Direito Internacional Público. $7^{\mathrm{a}}$ ed. São Paulo: Editora Revista dos Tribunais, 2013. p. 926.

${ }^{10}$ Formada por 35 países independentes das Américas, a OEA constitui o principal fórum governamental político, jurídico e social do Hemisfério. Seu objetivo, conforme estipula o Artigo $1^{\circ}$ da Carta, é alcançar "uma ordem de paz e de justiça, para promover sua solidariedade, intensificar sua colaboração e defender sua soberania, sua integridade territorial e sua independência”. Disponível em: <http://www.oas.org/pt/sobre/quem_somos.asp $>$. Acesso em: 10 set. 2016.

${ }^{11}$ MAZZUOLI, Op. cit., p. 926.

${ }^{12} \mathrm{O}$ rol de direitos está previsto na primeira parte da Declaração, entre os arts 1 a 28. Já o rol dos deveres encontra-se na segunda parte, entre os arts 29 a 38 . Disponível em: <https://www.cidh.oas.org/basicos/portugues/b.Declaracao_Americana.htm>. Acesso em: 10 set. 2016.
} 
membros da OEA, conforme posicionamento da Corte Interamericana de Direitos Humanos em sua Opinião Consultiva ${ }^{\circ} 10 / 1989^{13}$.

Após a adoção da Declaração e da Carta da OEA, deflagrou-se um processo gradual de promoção e proteção dos direitos humanos no sistema interamericano, cujo primeiro passo foi a criação de um órgão especializado para aprofundar esse processo no âmbito da OEA: a Comissão Interamericana de Direitos Humanos (doravante "Comissão" ou CIDH), aprovada na $5^{\mathrm{a}}$ Reunião de Ministros de Relações Exteriores, na cidade de Santiago do Chile, em 1959. A ideia inicial era a de que a Comissão funcionaria provisoriamente até a instituição de uma Convenção Internacional Americana, a qual seria aprovada em $1969^{14}$.

A Convenção Americana de Direitos Humanos (doravante “Convenção Americana" ou "CADH”), também conhecida como Pacto de San José da Costa Rica, entrou em vigor em 18 de julho de 1978 e se tornou o instrumento de maior importância no SIDH. Ela reconhece e assegura um amplo catálogo de direitos civis e políticos. Contudo, não enuncia de forma específica qualquer direito social, cultural ou econômico, limitando-se a determinar que os Estados persigam a plena realização desses direitos mediante a adoção de medidas legislativas e outras que se mostrem apropriadas, conforme disposto no art. 26 da Convenção. Posteriormente, em 1988, a Assembleia Geral da OEA adotou um Protocolo Adicional à Convenção, concernente aos direitos sociais, econômicos e culturais, também chamado de Protocolo de San Salvador, o qual entrou em vigor em novembro de $2009^{15}$.

A criação da CADH fortaleceu o sistema de direitos humanos implantado com a Carta da OEA e reforçado pela Declaração Americana,

\footnotetext{
${ }^{13}$ CORTE IDH. Interpretação da Declaração Americana dos Direitos e Deveres do Homem no Marco do Artículo 64 da Convenção Americana sobre Direitos Humanos. Opinião Consultiva OC10/89 de 14 de julho de 1989. Serie A No. 10, parágrafos 35-45. Disponível em: <http://www.corteidh.or.cr/docs/opiniones/seriea_10_esp1.pdf>. Acesso em: 09 set. 2016.

${ }^{14}$ MAZZUOLI, 2013, p. 926.

${ }^{15}$ PIOVESAN, Flávia. Direitos Humanos e Justiça Internacional. $3^{a}$ ed. São Paulo: Saraiva, 2012. p. 127-129.
} 
pois atribuiu mais efetividade à Comissão que, até então, funcionava apenas como órgão da OEA. Ademais, ela estabelece um aparato de monitoramento e implementação dos direitos que enuncia. Tal aparato é integrado pela já existente, e agora consolidada, Comissão Interamericana de Direitos Humanos, e por um novo órgão criado pela CADH: a Corte Interamericana de Direitos Humanos (doravante "Corte" ou "Corte IDH").

Tendo ficado clara a breve exposição de como o SIDH foi formado, na próxima parte serão explicadas, de forma resumida, a atuação de seus órgãos.

\subsection{Atuação dos órgãos do sistema interamericano}

Como mencionado, atualmente o Sistema Interamericano divide-se em dois órgãos: a Comissão Interamericana de Direitos Humanos (tópico 1.2.1) e a Corte Interamericana de Direitos Humanos (tópico 1.2.2).

\subsubsection{A Comissão Interamericana de Direitos Humanos}

Conforme estabelece o artigo $1^{\circ}$ de seu Estatuto ${ }^{16}$, a Comissão é um órgão da OEA criado para promover a observância e a defesa dos direitos humanos e para servir como órgão consultivo da Organização nesta matéria.

Dentre suas atribuições, previstas em seu Estatuto, em seu Regulamento ${ }^{17}$ e na $\mathrm{CADH}$, estão: o estímulo à consciência pública dos direitos humanos na América; a análise de casos individuais em que se alega alguma violação de direitos humanos por parte de Estados Membros da OEA; a publicação de informações especiais sobre a situação dos direitos humanos em um Estado específico; a realização de visitas in loco aos países para analisar em profundidade a situação geral, e/ou para

\footnotetext{
${ }^{16}$ Aprovado pela Resolução AG/RES 447 (IX-o/79)), adotada pela Assembleia Geral da OEA em seu Nono Período Ordinário de Sessões, realizado em La Paz, Bolívia, em outubro de 1979.

${ }^{17}$ Aprovado pela Comissão em seu $137^{\circ}$ período ordinário de sessões, celebrado de 28 de outubro a 13 de novembro de 2009; e modificado em 2 de setembro de 2011 e em seu $147^{\circ}$ período ordinário de sessões, celebrado de 8 a 22 de março de 2013.
} 
investigar uma situação particular, com posterior preparação de um relatório respectivo; fazer recomendações aos Estados membros da OEA acerca da adoção de medidas que contribuam para a proteção dos direitos humanos; a solicitação aos Estados membros que adotem medidas cautelares específicas, conforme disposto no artigo 25 de seu Regulamento; a solicitação para que a Corte requeira medidas provisionais dos Governos em casos de extrema gravidade e urgência; a apresentação de casos à jurisdição da Corte Interamericana, a solicitação de opiniões consultivas à Corte $^{18}$, conforme disposto no artigo 64 da Convenção ${ }^{19}$.

A interposição de uma petição na esfera internacional deve observar alguns requisitos de admissibilidade: o prévio esgotamento dos recursos internos e a inexistência de litispendência internacional - com exceção dos casos de injustificada demora processual ou no caso de não previsão pelo ordenamento jurídico interno ${ }^{20}$.

A partir do ano 1990, a Comissão começou a criar Relatorias Temáticas com o objetivo de atender a certos grupos, comunidades e povos que se encontravam especialmente expostos a violações de direitos humanos por sua situação de vulnerabilidade e discriminação histórica. A finalidade dessas Relatorias é fortalecer, impulsionar e sistematizar o trabalho da própria Comissão.

No que tange ao trabalho escravo contemporâneo, em 24 de dezembro de 2009 a Comissão publicou o informe "Comunidades Cautivas: Situación del Pueblo Indígena Guaraní y Formas Contemporáneas de Esclavitud en el Chaco de Bolivia"21. Esse relatório foi resultado de uma visita de trabalho e observação - visita in loco - realizada

\footnotetext{
${ }^{18}$ Essa é a explicação da própria Comissão. Disponível em: <http://www.oas.org/es/cidh/mandato/relatorias.asp>. Acesso em: 12 set. 2016.

${ }^{19}$ Mandato e funções da CIDH. Disponível em:

$<$ http://www.oas.org/pt/cidh/mandato/funciones.asp>. Acesso em: 10 set. 2016.

${ }^{20}$ Art 31 do Regulamento da Comissão.

21 CIDH. Comunidades Cautivas: Situación del Pueblo indígena guaraní y formas contemporâneas de esclavitud en el Chaco de Bolivia. OEA/Ser.L/V/II. Doc 58. 24 diciembre 2009. Disponível em: <http://www.cidh.org/pdf\%20files/COMUNIDADES\%20CAUTIVAS.pdf〉. Acesso em: 11 set. 2016.
} 
em 2008 pela Relatoria para a Bolívia e pela Relatoria sobre os Direitos dos Povos Indígenas. Por se tratar de um relatório que discute situações muito particulares da Bolívia, ele será utilizado nesse trabalho apenas como fonte consultiva.

Quando recebe uma petição, a Comissão decide sua admissibilidade, levando em conta o disposto no artigo 46 da CADH. Uma vez admitida a petição, a Comissão passa a examinar as alegações do peticionário, a buscar informações no respectivo governo, a investigar os fatos e a realizar a oitiva tanto do peticionário quanto do governo. Após, a Comissão deve buscar uma Solução Amistosa, a qual está prevista no artigo 40 do Regulamento da Comissão ${ }^{22}$. Quando frutífera, é transmitido um comunicado ao peticionário e ao Estado seguido de publicação pela Secretaria da OEA. Em caso de não se chegar a um consenso, a Comissão redige um relatório detalhando os fatos e o direito envolvidos, podendo fazer recomendações ao Estado. No prazo de três meses, o caso pode ser resolvido ou encaminhado à Corte.

A primeira denúncia que chegou à Comissão Interamericana sobre exploração de trabalho escravo contemporâneo foi contra o Estado do Brasil, pelo incidente conhecido como "Caso José Pereira"23. E foi no ceio da Comissão que as partes chegaram a uma Solução Amistosa, em setembro de 2003, por meio da qual o Brasil reconheceu sua responsabilidade

\footnotetext{
${ }^{22}$ Artigo 40. Solução amistosa 1. Em qualquer etapa do exame de uma petição ou caso, a Comissão, por iniciativa própria ou a pedido das partes, pôr-se-á à disposição destas a fim de chegar a uma solução amistosa sobre o assunto, fundamentada no respeito aos direitos humanos estabelecidos na Convenção Americana sobre Direitos Humanos, na Declaração Americana e em outros instrumentos aplicáveis. 2. O início e a continuação do procedimento de solução amistosa basear-se-ão no consentimento das partes.3. A Comissão, quando assim considerar necessário, poderá atribuir a um ou mais dos seus membros a tarefa de facilitar a negociação entre as partes. 4. A Comissão poderá dar por concluída sua intervenção no procedimento de solução amistosa se advertir que o assunto não é suscetível de solução por esta via ou se alguma das partes decidir retirar-se do mesmo, não concordar com sua aplicação ou não mostrar-se disposta a chegar a uma solução amistosa fundamentada no respeito aos direitos humanos. 5. Se for alcançada uma solução amistosa, a Comissão aprovará um relatório que incluirá uma breve exposição dos fatos e da solução alcançada e será transmitido às partes e publicado. Antes de aprovar esse relatório, a Comissão verificará se a vítima da presumida violação ou, se pertinente, seus beneficiários, expressaram seu consentimento no acordo de solução amistosa. Em todos os casos, a solução amistosa deverá ter por base o respeito aos direitos humanos reconhecidos na Convenção Americana sobre Direitos Humanos, na Declaração Americana e em outros instrumentos aplicáveis. 6. Se não for alcançada uma solução amistosa, a Comissão dará prosseguimento à tramitação da petição ou caso.

${ }^{23}$ Informe no 95/03. Petición 11.289. Solução Amistosa. José Pereira e Brasil.
} 
internacional pela violação dos direitos humanos praticada por particulares $^{24}$. Essa Solução Amistosa pode ser considerada um marco no combate ao trabalho escravo contemporâneo no Brasil, motivo pelo qual será intensamente analisada no presente trabalho. Além da Comissão, o SIDH também dispõe de uma Corte, a qual será abordada a seguir.

\subsubsection{A Corte Interamericana de Direitos Humanos}

A Corte Interamericana é o órgão jurisdicional do SIDH, com sede em San José, na Costa Rica. O órgão foi criado pela Convenção em 1969, mas apenas começou a funcionar em 1980 (um ano após a entrada em vigor do referido tratado), quando emitiu sua primeira Opinião Consultiva ${ }^{25}$. Trata-se de uma instituição autônoma da OEA, com o objetivo de aplicar e interpretar a $\mathrm{CADH}$ e outros tratados de direitos humanos e suas funções são regidas tanto pela CADH quanto pelo seu Regulamento e Estatuto. Ela é composta por sete juízes de nacionalidades diferentes e provenientes dos Estados-membros da OEA. As atribuições da Corte competem a duas funções distintas: a consultiva e a contenciosa ${ }^{26}$.

\section{a) Funcão Consultiva}

\footnotetext{
${ }^{24}$ Em 1995 o Governo Brasileiro reconheceu oficialmente a existência de trabalho em condição análoga à de escravo no país perante o Comitê de Direitos Humanos e começou a tomar medidas para erradicá-lo. Ver: BRASÍLIA. Ministério do Trabalho. Manual de Combate ao Trabalho em Condições Análogas às de Escravo, 2011. p. 8.

SHAHINIAN, Gulnara. ONU. Human Rights Council. Report of the Special Rapporteur on contemporary forms of slavery, inclluding its causes and consequences, Gulnara Shahinian. Missio to Brazil. 30 ago. 2010. p. 4.

OIT. Combatendo o trabalho escravo contemporâneo: o exemplo do Brasil, 2010, p. 31.

No caso José Pereira, todavia, o reconhecimento foi um pouco diferente, pois não apenas reconheceu genericamente a existência de trabalho escravo, mas reconheceu a responsabilidade por aquele caso específico e pela existência de casos semelhantes perpetrados por particulares sob a negligência estatal. É válido ressaltar, ainda, que desde 1980, órgãos de controle da OIT, que acompanhavam a aplicação da Convenção $n^{\circ} 29$, vinham analisando o problema do trabalho forçado no Brasil.

${ }^{25}$ Veremos mais adiante o que são as "Opiniões Consultivas".

26 Para uma análise mais aprofundada acerca da história da Corte, ler: Disponível em: <http://www.corteidh.or.cr/index.php/es/acerca-de/historia-de-la-corteidh>. Acesso em: 12 set. 2016.
} 
No plano consultivo, qualquer Estado membro da OEA - parte ou não da Convenção Americana - pode solicitar um parecer da Corte em relação à interpretação da Convenção ou de qualquer outro tratado relativo à proteção dos Direitos Humanos aplicável aos Estados americanos ${ }^{27}$. A Corte também pode opinar sobre a compatibilidade da legislação doméstica em face de instrumentos internacionais, efetuando o chamado "controle de convencionalidade das leis". Importante mencionar que a Corte efetua uma interpretação dinâmica e evolutiva dos direitos humanos enunciados na $\mathrm{CADH}$, considerando o contexto temporal e as transformações sociais, o que permite a expansão dos direitos ${ }^{28}$.

Cabe ressaltar que, embora a competência contenciosa da Corte seja facultativa, limitada aos Estados-parte da Convenção que reconheçam expressamente sua jurisdição, a competência consultiva é automaticamente aceita pelos Estados-partes que ratificaram o referido tratado ${ }^{29}$.

Jo Pasqualucci destaca que:

A Corte Interamericana de Direitos Humanos tem a mais ampla jurisdição em matéria consultiva, se comparada com qualquer outro Tribunal Internacional. As opiniões consultivas são mecanismos com muito menor grau de confronto que os casos contenciosos, não sendo limitadas a fatos específicos, servindo, na verdade, para conferir expressão judicial aos princípios jurídicos ${ }^{30}$.

Em sua primeira Opinião Consultiva, a Corte esclareceu que essa competência pode alcançar outros tratados concernentes à proteção dos direitos humanos nos Estados americanos, sem que nenhuma parte esteja excluída do âmbito dessa função assessora ${ }^{31}$.

\footnotetext{
${ }^{27}$ Disposição do Art 64 da CADH.

${ }^{28}$ PIOVESAN, 2012, p. 139-140.

${ }^{29}$ MAZZUOLI, 2013, p. 936.

${ }^{30}$ PASQUALUCCI, Jo. The practice and procedure of the Inter-American Court on Human Rights. p. 80. In: PIOVESAN, Flávia. Direitos Humanos e Justiça Internacional. $3^{\mathrm{a}}$ ed. São Paulo: Saraiva, 2012. p. 140.

${ }^{31}$ Corte IDH. Otros Tratados objeto de La Función Consultiva de La Corte. (Art. 64 Convención Americana sobre Derechos Humanos). Opinião Consultiva OC-1/82 de 24 de setembro de 1982, p. 14.
} 
No que tange ao trabalho escravo contemporâneo, ainda não foi emitida nenhuma Opinião Consultiva pela Corte em relação a essa temática. Além da função consultiva, a Corte também tem uma função contenciosa.

\section{b) Função Contenciosa}

A competência contenciosa tem caráter jurisdicional, referente à solução de controvérsias que se apresentem acerca da interpretação ou aplicação da própria Convenção ${ }^{32}$. Essa competência está prevista na CADH em seus artigos 61, 62 e 63 e abrange tanto a possibilidade de analisar e decidir medidas provisórias quanto casos concretos em que se considere haver violações à CADH cometidas por determinado Estado parte. É válido ressaltar que essa competência é exercida apenas em relação aos Estados que tenham expressamente aceitado a jurisdição contenciosa da corte, posto que o Art 62 da $\mathrm{CADH}$ é uma cláusula facultativa ${ }^{33}$. Isto significa que um Estado-parte na Convenção Americana não pode ser demandado perante a Corte se ele próprio não aceitar a sua competência contenciosa $^{34}$. A Corte não relata casos e não faz qualquer tipo de recomendação no exercício de sua competência contenciosa, mas profere sentenças definitivas e inapeláveis, conforme dispõe o art. 67 da Convenção.

No exercício de sua competência contenciosa, a Corte já se pronunciou sobre a violação ao artigo $6^{\circ}$ da $\mathrm{CADH}$, o qual proíbe a escravidão e a servidão, em casos como os seguintes: Massacres do Rio Negro vs. Guatemala, julgado em 4 de setembro de $2012^{35}$ e Massacres de Ituango vs. Colômbia, julgado em 1 de julho de $2006^{36}$. Não obstante esses

\footnotetext{
32 PIOVESAN, 2012, p. 139.

33 O Brasil reconheceu a competência contenciosa da Corte em 1998, por meio do Decreto Legislativo ${ }^{\circ} 89$, de 3 de dezembro do mesmo ano.

${ }^{34}$ MAZZUOLI, 2013, p. 936.

35 CORTE IDH. Caso Massacres do Rio Negro vs. Guatemala. Sentença de 4 de setembro de 2012.

A Corte se pronuncia sobre o Trabalho Escravo nos parágrafos 136-150.

${ }^{36}$ CORTE IDH. Caso Massacres de Ituango vs. Colombia. Sentença de 1 de julho de 2006.

A Corte se pronuncia sobre o Trabalho Escravo nos parágrafos 145-168.
} 
pronunciamentos prévios, nos casos mencionados a temática central não era a exploração de trabalho escravo contemporâneo.

O primeiro caso cuja temática central é a exploração de trabalho escravo foi recebido pela Corte em 4 de março de 2015 e está próximo de ser julgado. Trata-se do Caso Brasil Verde, contra o Estado do Brasil, sobre o qual discutiremos mais profundamente em capítulo próprio no presente trabalho ${ }^{37}$.

\footnotetext{
${ }^{37}$ As informações sobre o trâmite do caso Brasil Verde vs. Brasil perante a Corte. Disponível em: $\langle$ http://www.corteidh.or.cr/docs/tramite/trabajadores_de_la_hacienda_brasil_verde.pdf $\rangle$. Acesso em: 10 set. 2016.
} 


\section{CAPÍTULO 2 - SOLUÇÃO AMISTOSA NO CASO JOSÉ PEREIRA VS. BRASIL}

Após termos estudado brevemente o SIDH, a partir de agora começaremos a analisar como o mesmo tem atuado no que tange ao trabalho escravo no Brasil. Para possibilitar essa análise, o presente capítulo será dividido em quatro objetivos: (i) esclarecer o conceito internacional de trabalho escravo contemporâneo; (ii) apresentar o contexto em que se insere o trabalho escravo contemporâneo no Brasil; (iii) expor e analisar os fatos do Caso José Pereira contra o Brasil e seu trâmite perante a Comissão; e (iv) estudar as cláusulas do Acordo de Solução Amistosa alcançado entre as partes do processo.

Nesse sentido, o capítulo tem o propósito de elucidar as futuras contribuições do Caso José Pereira para a não violação dos Direitos Humanos no Brasil no que toca o trabalho escravo contemporâneo nas áreas rurais.

\subsection{O conceito de trabalho escravo}

Em 1930 foi aprovada a Convenção $\mathrm{n}^{\circ} 29$ da Organização Internacional do Trabalho (OIT), "Sobre Trabalho Forçado ou Obrigatório", a qual foi ratificada em 1957 pelo Brasil ${ }^{38}$. Por meio dela, todos os Estadosmembros da OIT comprometeram-se a "abolir a utilização do trabalho forçado ou obrigatório, em todas as suas formas, no mais breve espaço de tempo possível". Para cumprir essa meta, a Convenção $n^{\circ} 29$ definiu o trabalho forçado para o direito internacional como:

\footnotetext{
${ }^{38}$ A Convenção ${ }^{\circ}$ 29/1930 da OIT foi ratificada no Brasil por meio do Decreto $\mathrm{N}^{\circ} 41.721$ de 25 de junho de 1957. Disponível em:

<http://www.planalto.gov.br/ccivil_03/decreto/Antigos/D41721.htm\#convencao29>. Acesso em: 30 out. 2016.
} 
Todo trabalho ou serviço exigido de uma pessoa sob a ameaça de sanção e para o qual não se tenha oferecido espontaneamente.

A definição de trabalho forçado presente na convenção $n^{\circ} 29$ é composta por dois elementos: ameaça de uma pena (ou punição) e (ausência de) consentimento. Reunidos, esses dois elementos tipificam diferentes situações de trabalho forçado abrangidas pela Convenção. Essa concepção buscou abarcar as diversas possibilidades de trabalho forçado, desde a escravidão colonial até a contemporânea, incluindo o trabalho penitenciário e até o tráfico de seres humanos. A partir dessa abordagem, cada país é responsável por adotar legislação particular, tipificando essa prática de forma detalhada, a fim de sancioná-la adequadamente ${ }^{39}$. Atualmente, ainda é esta a definição adotada pela legislação internacional.

Por óbvio que o entendimento não é tão literal como aparenta. Há vicissitudes que causam discussões acerca do tema em âmbito internacional como, por exemplo, a questão do consentimento (ou também chamado de voluntariedade). A OIT tem estudado aspectos relacionados à liberdade de escolha, entendendo que "o consentimento inicial pode ser considerado irrelevante quando obtido por engano ou fraude" 40 .

Além da Convenção n ${ }^{\circ} 29$, existe também a Convenção $n^{\circ} 105$, de 1957, sobre Abolição do Trabalho Forçado, ratificada pelo Brasil em $1966^{41}$. Essa Convenção é complementar à de n 29 e não traz modificações à definição de trabalho forçado prevista nela. Enquanto a de $\mathrm{n}^{\circ} 29$ estabelece proibições genéricas de trabalho forçado, admitindo algumas

\footnotetext{
${ }^{39}$ OIT. Combatendo o trabalho escravo contemporâneo: o exemplo do Brasil, 2010, p. 37.

40 Relatório Global do Seguimento da Declaração da OIT sobre Princípios e Direitos Fundamentais no Trabalho. Uma Aliança Global Contra o Trabalho Forçado. Genebra: Secretaria Internacional do Trabalho, Conferência Internacional do Trabalho, 93ª Reunião, 2005.

${ }^{41}$ A Convenção no $105 / 1957$ da OIT foi ratificada pelo Brasil por meio do Decreto n. 58.822/1966. Disponível em: <http://www.planalto.gov.br/ccivil_03/decreto/1950-1969/D58822.htm>. Acesso em: 31 out. 2016.
} 
poucas exceções, a de $n^{\mathbf{o}} 105$ proíbe o trabalho forçado em situações específicas $^{42}$.

É importante mencionar também a Convenção Americana sobre os Direitos Humanos, já introduzida no primeiro capítulo do presente trabalho. Em seu artigo $6^{\circ}$ ela proíbe a escravidão e a servidão. Todavia, a Convenção não traz definições. O Art. 6.1 apenas proíbe a submissão à escravidão ou servidão e o Art. 6.2 determina que ninguém deve ser constrangido a executar trabalho forçado ou obrigatório ${ }^{43}$.

Conforme mencionado no capítulo anterior, a Corte IDH já teve a oportunidade de se manifestar brevemente sobre o alcance do artigo $6^{\circ}$ da $\mathrm{CADH}$, no caso Massacres de Ituango vs. Colômbia ${ }^{44}$, julgado em $2006 . \mathrm{Na}$ ocasião, interpretou o Art. 6.2 CADH à luz da definição de trabalho forçado conferido pela Convenção No 29 da OIT, acima exposto. A Corte reiterou os dois elementos presentes nesse conceito e acrescentou que, para configurar uma violação à Convenção Americana, outro elemento deve ser analisado:

Además, este Tribunal considera que, para constituir una violación del artículo 6.2 de la Convención Americana, es necesario que la presunta violación sea atribuible a agentes del Estado, ya sea por medio de la participación directa de éstos o por su aquiescencia en los hechos ${ }^{45}$.

Portanto, para a Corte IDH, além da ameaça de uma pena e da ausência de consentimento, para que se considere que o artigo $6^{\circ}$ da $\mathrm{CADH}$

42 INTERNATIONAL LABOUR ORGANIZATION (ILO). Forced Labour and Human Trafficking: Casebook of Court Decisions. Geneva, 2009. p. 11.

${ }^{43}$ Art. 6. Proibicão da escravidão e da servidão:

1. Ninguém pode ser submetido a escravidão ou a servidão, e tanto estas como o tráfico de escravos e o tráfico de mulheres são proibidos em todas as suas formas.

2. Ninguém deve ser constrangido a executar trabalho forçado ou obrigatório. Nos países em que se prescreve, para certos delitos, pena privativa da liberdade acompanhada de trabalhos forçados, esta disposição não pode ser interpretada no sentido de que proíbe o cumprimento da dita pena, imposta por juiz ou tribunal competente. $\mathrm{O}$ trabalho forçado não deve afetar a dignidade nem a capacidade física e intelectual do recluso.

${ }^{44}$ No primeiro capítulo também mencionamos o Caso Massacres do Río Negro vs. Guatemala. Contudo, ao nosso ver, a Corte não aproveitou a oportunidade para discorrer sobre esse tipo de violação de Direitos Humanos, apenas afirmou de forma muito breve que o Art $6^{\circ} \mathrm{CADH}$ foi violado, sem conferir muitas explicações. Por tal motivo, não discorreremos sobre esse caso.

${ }^{45}$ CORTE IDH. Caso Massacres de Ituango vs. Colombia. Sentença de 1 jul. 2006. Parágrafo 160. 
foi violado, é necessário que a violação seja atribuível a agentes estatais, tanto por sua participação direta quanto por sua aquiescência.

Em relação à discussão conceitual travada no Brasil, afirma o Ministério do Trabalho e Emprego:

Diversas são as denominações dadas ao fenômeno de exploração ilícita e precária do trabalho, ora chamado de trabalho forçado, trabalho escravo, exploração do trabalho, semiescravidão, trabalho degradante, entre outros, que são utilizados indistintamente para tratar da mesma realidade jurídica. Em diversos documentos internacionais e nacionais encontramos variações entre os conceitos usados, indo simplesmente de 'trabalho escravo' a 'trabalho em condições análogas à escravidão, ${ }^{46}$.

No Brasil não existe uma definição normativa expressa sobre o que seria o "trabalho forçado" previsto nas Convenções da OIT, salvo pela vedação ao trabalho forçado no art. $5^{\circ}$, XLVII, $c$, da Constituição Federal. Contudo, a Constituição protege o trabalho com dignidade. Elenca como fundamentos do Estado Democrático de Direito a dignidade (art 1, III, CRFB) e os valores sociais do trabalho (art. $1^{\circ}$, IV , CRFB). Ademais, inclui o direito ao trabalho como um direito social (art $6^{\circ} \mathrm{CRFB}$ ) e dedica o art. $7^{\circ}$ CRFB aos direitos dos trabalhadores.

$\mathrm{Na}$ legislação trabalhista, curiosamente, tampouco há menção expressa ao trabalho forçado, mas é possível identificar normas que determinam parâmetros de trabalho, como higiene (art 154 a 159 CLT), equipamento de segurança (art 158, parágrafo único, b, CLT), descansos remunerados (arts 66 a 72 CLT) e demais condições.

É na esfera penal que se encontram alguns conceitos, mas que também não suficientemente claros. O art. 149 do Código Penal traz a seguinte redação:

Art. 149. Reduzir alguém a condição análoga à de escravo, quer submetendo-o a trabalhos forçados ou a jornada exaustiva, quer sujeitando-o a condições degradantes de trabalho, quer restringindo, por qualquer meio, sua locomoção

\footnotetext{
${ }^{46}$ MINISTÉRIO DO TRABALHO E EMPREGO (MTE). Manual para combate ao Trabalho em condições análogas a de escravo. Brasília, 2011. p. 12.
} 
em razão de dívida contraída com o empregador ou preposto: (Redação dada pela Lei $\mathrm{n}^{\mathrm{o}} 10.803$, de 11.12.2003). (grifei)

Pena - reclusão, de dois a oito anos, e multa, além da pena correspondente à violência. (Redação dada pela Lei no ${ }^{\circ} 10.803$, de 11.12.2003).

$\S 1^{\circ}$ Nas mesmas penas incorre quem: (Incluído pela Lei $\mathrm{n}^{\circ} 10.803$, de 11.12.2003).

I - cerceia o uso de qualquer meio de transporte por parte do trabalhador, com o fim de retê-lo no local de trabalho; (Incluído pela Lei no 10.803 , de 11.12.2003).

II - mantém vigilância ostensiva no local de trabalho ou se apodera de documentos ou objetos pessoais do trabalhador, com o fim de retê-lo no local de trabalho. (Incluído pela Lei no ${ }^{\circ} 10.803$, de 11.12.2003).

Essa redação foi dada após uma modificação legal realizada no ano de 2003, cujo objetivo era fechar o tipo penal. Porém, persistem os conceitos difusos e indeterminados. Destaque-se que existem três figuras equiparadas descritas pelo tipo: "trabalho escravo", "jornadas exaustivas" e "condições degradantes", as quais não são definidas pela norma, tampouco são concedidos parâmetros ao intérprete para aplicação do direito.

Apesar das diversas denominações, segundo o Ministério do Trabalho e Emprego:

Qualquer trabalho que não reúna as mínimas condições necessárias para garantir os direitos do trabalhador, ou seja, cerceie sua liberdade, avilte a sua dignidade, sujeite-o a condições degradantes, inclusive em relação ao meio ambiente de trabalho, há que ser considerado trabalho em condição análoga à de escravo ${ }^{47}$.

Já segundo a OIT Brasil, no âmbito nacional, vários e distintos termos podem ser abordados para designar trabalho forçado. A Organização ressalta, porém, que no Brasil, o termo mais usado para se referir às "práticas coercitivas de recrutamento e emprego é trabalho escravo"48.

\footnotetext{
${ }^{47}$ MINISTÉRIO DO TRABALHO E EMPREGO (MTE). Manual para combate ao Trabalho em condições análogas a de escravo. Brasília, 2011. p. 12.

${ }^{48}$ OIT. Combatendo o trabalho escravo contemporâneo: o exemplo do Brasil, 2010, p. 33.
} 
Resta claro, pois, que a própria definição do trabalho escravo ainda é um assunto muito discutido, posto que não existe homogeneidade quanto ao seu conteúdo. Percebe-se uma interseção entre o direito do trabalho, o direito penal e os direitos humanos, sendo possível violações às normas dessas três esferas jurídicas.

Diante da existência de uma enorme discussão acerca do significado e dos elementos que configuram o trabalho escravo, para os fins dessa monografia, todos esses termos mencionados acima serão entendidos como sinônimos e optamos por adotar "trabalho escravo contemporâneo" por se tratar de uma forma mais genérica de abordar a temática.

\subsection{Breve contextualização do trabalho escravo contemporâneo no Brasil}

O presente trabalho não tem como objetivo discorrer profundamente sobre as questões históricas e sociais que acabam por legitimar a exploração de trabalho escravo até os dias atuais. Todavia, uma breve contextualização se faz necessária para tornar mais claros alguns aspectos, como a abordagem jurídica atual acerca desse problema, os entraves políticos, econômicos e sociais para erradicar de vez essa prática, bem como o contexto em que se inserem os fatos dos Casos José Pereira e Fazenda Brasil Verde. Dividiremos esse tópico em: (i) contexto histórico e (ii) perfil dos trabalhadores aliciados ao trabalho escravo contemporâneo.

\section{(i) Contexto Histórico}

Segundo a historiadora María Helena P. T. Machado, nenhuma instituição social, sistema de exploração de trabalho ou de visão de mundo sobreviveu tão longamente no Brasil como a escravidão, a qual remonta à época de colonização do país no século XVI. A escravidão, enquanto sistema de exploração de trabalho e artefato ideológico, entranhou suas 
raízes na formação social do "Brasil colônia" de forma tão definitiva que sobreviveu às crises causadas pela superação do regime colonial, perpetuando-se ainda hoje $\mathrm{e}^{49}$.

Em 1531 o Rei João III de Portugal enviou os primeiros colonos ao Brasil, que inicialmente escravizaram os indígenas e, em seguida, pessoas provenientes do continente africano. Em meados do século XVIII, aproximadamente quarenta por cento da população escrava no Brasil se ocupavam do cultivo de cana de açúcar ${ }^{50}$.

No século XIX todas as atividades econômicas do Brasil eram baseadas na escravidão colonial, a qual não se constituía apenas em um modo de produção, mas fazia parte da estrutura social, fundamentada em padrões de exploração de difícil desconstrução. Em 1850 foi proibido o comércio transatlântico de escravos, movimento que fortaleceu a pressão para a abolição total da escravidão, a qual só seria decretada no Brasil em 13 de maio de 1888, por meio da assinatura da Lei Áurea, que proibiu o direito de propriedade de uma pessoa sobre a outra ${ }^{51}$.

No ano de 1850 , a Lei de Terras foi aprovada no Brasil, com o intuito de regular o acesso à terra. Essa Lei estabelecia que as terras devolutas seriam atribuídas ao Estado, o qual poderia, então, vendê-las ao invés de doá-las. Todavia, o preço dessas terras apenas era acessível aos senhores de terras, pois extremamente elevado para a população menos favorecida, como os ex-escravos. Consequentemente, os grandes latifundiários eram capazes de aumentar ainda mais o tamanho de suas propriedades, enquanto o resto da população era excluída do novo processo oficial de aquisição de terras. Portanto, o sistema em que a terra era concentrada nas mãos de poucos indivíduos foi fortalecido e, para sobreviver, os ex-escravos se viram obrigados a continuar oferecendo sua

\footnotetext{
49 AGUIRRE, Carlos et al.. La abolición de la esclavitud em hispanoamérica y Brasil. Nuevos aportes y debates historiográficos. p. 66. Fundación Ignacio Larramendi. Acesso em: 24 out. 2016.

${ }^{50}$ SHAHINIAN, 2010, p. 3.

${ }^{51}$ OIT. Combatendo o trabalho escravo contemporâneo: o exemplo do Brasil, 2010, p. 113.
} 
mão-de-obra aos grandes latifúndios de fazendeiros e produtores agrícolas em troca de salários irrisórios, onde a tendência de exploração laboral desencadearia uma "reconfiguração do trabalho escravo" 52 .

No século $\mathrm{XX}$, iniciou-se o processo de extração do látex para fabricação da borracha, fato que inseriu a região amazônica em seu primeiro ciclo econômico significativo e, consequentemente, ao processo de industrialização. Devido a esse crescente desenvolvimento, um grande número de trabalhadores do Nordeste brasileiro foi atraído para trabalhar na Região Norte $^{53}$. Além da exploração do látex, a região foi sujeita a flutuações populacionais devidas aos eventos relativos à posterior crise da borracha, à extração da castanha do Pará e do ouro e à agropecuária empresarial ${ }^{54}$.

A industrialização da região continuou se intensificando e se expandiu o fenômeno da "posse ilegal e adjudicação descontrolada das terras públicas" (grilagem) ${ }^{55}$. Durante a Ditadura Militar, na década de 1970, foi lançado o Plano de Integração Nacional pelo Governo Federal. Esse Plano tinha, dentre seus objetivos, aproveitar e desenvolver melhor a região da Amazônia. Foram feitas análises das propriedades rurais do estado do Pará e constatou-se que quase não existiam propriedades regulares, com titulação passível de reconhecimento legal, motivo pelo qual as mesmas foram consideradas propriedades do Governo. Iniciou-se, então, um processo de implementação de projetos de agronegócio com intensos incentivos fiscais para a instalação de grandes indústrias na região. Segundo a Organização Internacional do Trabalho (OIT), nesse momento começou a crescer, descontroladamente, a distribuição de terras públicas às corporações, e na mesma medida se intensificavam a destruição da Floresta

\footnotetext{
${ }^{52}$ SHAHINIAN, Op. cit., p. 3.

${ }^{53}$ OIT. Op. cit., p. 61-65.

${ }^{54}$ A agropecuária empresarial era incentivada pela Superintendência para o Desenvolvimento da Amazônia (SUDAM). Idem., p. 62.

${ }_{55}$ CIDH. Caso Brasil Verde vs. Brasil. Relatório $N^{\circ}$ 169/11. Relatório de Mérito de 3 de novembro de 2011. p. 62-64.
} 
Amazônica, o desemprego, a pobreza e a violência rural. Aumentava geometricamente também, a ocupação ilegal de grandes extensões dessas terras públicas por especuladores ${ }^{56}$.

Desde então, a posse ilegal de terras é uma questão crítica na Região da Amazônia, especialmente no estado do Pará. Por meio de fraude e de cumplicidade com funcionários públicos, foram obtidos milhares de títulos de propriedade falsos, os quais foram vendidos e revendidos tantas vezes que se tornou impossível denominar os donos verdadeiros. Também se tornou comum a privatização irregular das terras por meio da "grilagem" e do despejo forçado e violento dos pequenos agricultores que há anos ocupavam essas terras ${ }^{57}$.

Nesse contexto sócio-econômico, existia uma ausência de autoridades do Estado brasileiro durante o processo de desenvolvimento dessa região, o que acabava permitindo a formação de alianças entre as autoridades regionais e os latifundiários, o que possibilitou a continuação da apropriação irregular de terras e a manutenção de relações de trabalho ilegais marcadas pela violência. Some-se a isso o fato de apenas a escassa e mal paga polícia se fazer presente na região na forma do Estado e a existência de um número limitado de juízes e promotores amedrontados. Estabeleceu-se, então, um ambiente propício para a consolidação da prática de trabalho escravo em fazendas de empresas privadas ou empresas familiares proprietárias de amplas extensões de terra ${ }^{58}$ e diversos conflitos fundiários ${ }^{59}$.

\footnotetext{
${ }^{56}$ OIT. Combatendo o trabalho escravo contemporâneo: o exemplo do Brasil, 2010, p. 62. SHAHINIAN, 2010, p. 25.

${ }^{57}$ OIT. Op. cit., 2010, p. 62-63.

${ }^{58}$ OIT. Op. cit., 2010, p. 63-64.

${ }^{59}$ É interessante mencionar que muitos trabalhadores que conseguem fugir ou são resgatados, se filiam ao Movimento dos Trabalhadores Rurais Sem Terra. (MST). Devido à todo esse contexto, brevemente abordado nesse trabalho, de concentração histórica de terras e de condições degradantes de trabalho, são testemunhados muitos casos de violência rural. A Corte IDH já julgou um caso envolvendo a violência rural no Brasil em que membros do MST foram vítimas de graves violações de Direitos Humanos. Ver:

CORTE IDH. Caso Escher e outros vs. Brasil. Sentença de 6 de julho de 2009.
} 
É importante frisar que, desde o início do século XX, já era uma realidade da Região Norte o trabalho realizado sob coerção para extração do látex das seringueiras. Nas décadas de 1970 e 1980 essa prática foi intensificada com a instalação de empresas agropecuárias que acarretaram diversos danos sociais e ambientais e, como consequência, geraram conflitos agrários extremamente violentos ${ }^{60}$.

A questão da pobreza no Brasil, bem como a da histórica concentração fundiária, está intrinsecamente relacionada como causa da exploração da mão de obra análoga à escrava.

Diante de todas essas informações, é relevante concluir esse tópico com um resumo, em linhas breves, desenvolvido pela Doutora Marcela Soares acerca da perpetuação dessa base estrutural escravista brasileira até os dias atuais, que justifica um enorme entrave ao enfrentamento ao trabalho escravo contemporâneo:

A história do trabalho escravo no brasil e os marcos normativos apresentam características que foram implementados de fora, apesar de nossa história apresentar a resistência dos escravos e de um pequeno setor da burguesia abolicionista. Não houve um processo que abalasse toda a estrutura social, que transformasse todas as esferas sociais da nossa formação social: a cultura, a política e a economia. Estas foram redesenhadas, remodeladas de acordo com os interesses externos (burguesia imperialista) e da burguesia dependente. Assim, a modernidade fora implementada onde era inevitável e a classe dominante brasileira se aproveitou das disparidades regionais, para manter os traços arcaicos/pré-capitalistas que viabilizassem a permanência de seus privilégios ${ }^{61}$.

\section{(ii) Perfil dos Trabalhadores Aliciados ao Trabalho Escravo}

\section{Contemporâneo}

Sem terra, sem trabalho e, portanto, sem suporte para sustentar a si mesmo e a família, alguns trabalhadores se submetem à exploração. Eles geralmente são recrutados de estados caracterizados pela extrema pobreza,

\footnotetext{
${ }^{60}$ OIT. Combatendo o trabalho escravo contemporâneo: o exemplo do Brasil, 2010, p. 64-65.

${ }^{61}$ SOARES, Marcela. Como Erradicar o Trabalho Escravo no Brasil? Notas a Propósito do Relatório da ONU. Brasiliana - Journal for Brazilian Studies. Vol. 2, n. 2 (Nov. 2013). ISSN 2245-4373.
} 
analfabetismo e desemprego rural. Segundo informações do Ministério do Trabalho concedidas à Relatora Especial da ONU para o trabalho escravo, Gulnara Shahinian, os três estados brasileiros com a maior oferta de trabalhadores são o Maranhão, o Piauí e Tocantins. Os estados com maior demanda, por sua vez, são o Pará, o Mato Grosso, o Maranhão e Tocantins. A Relatora expõe, ainda, que os relatórios do Ministério do Trabalho indicam que as principais atividades que empregam o trabalho escravo são a pecuária (38\%), a produção agrícola em grande escala de culturas (25\%) como a cana de açúcar -, o desmatamento e a silvicultura (14\%) e o carvão (3\%). Esses setores atraem muitos trabalhadores pois exigem apenas a capacidade e execução de trabalho manual. Essas pessoas em situação de trabalho escravo normalmente são homens entre 15 a 40 anos de idade e vivem longe de suas famílias, cuja renda é extremamente baixa ${ }^{62}$.

A grande maioria desses trabalhadores estão em situação de servidão por dívida. Os chamados "gatos"63 aliciam trabalhadores das regiões mais pobres do país, geralmente o Nordeste, para trabalharem em cidades distantes com a promessa de salários atraentes em troca de um adiantamento. Eles são recrutados por contrato verbal e levados de ônibus para as plantações e fazendas, geralmente localizadas em estado distinto dos de origem. Ao chegarem ao destino, recebem a informação de que terão de pagar de volta o adiantamento recebido e pelo transporte, bem como pela comida e acomodação. Os atraentes salários prometidos são reduzidos, insuficientes para cobrir os gastos já assumidos. Dessa forma, os trabalhadores se tornam endividados desde o início para com os empregadores. Eles raramente têm acesso a informação sobre como suas dívidas foram calculadas, e tampouco recebem seus salários em dinheiro. Em alguns casos, os trabalhadores se tornam cada vez mais endividados,

\footnotetext{
${ }^{62}$ SHAHINIAN, 2010, p. 7.

63 "Gato" é um termo usado para nomear os contratadores de mão-de-obra a serviço do fazendeiro. Eles aliciam os trabalhadores, servindo de fachada para que os fazendeiros não sejam responsabilizados. Ver: OIT - ORGANINZAÇÃO INTERNACIONAL DO TRABALHO. Trabalho Escravo no Brasil do Século XXI. $1^{a}$ ed., SAKAMOTO, Leonardo (Coord.). Brasil, 2006.
} 
tendo em vista que precisam comprar absolutamente tudo o que precisam para sobreviver nas lojas da propriedade em que trabalham, em que os preços são super inflacionados. Portanto, as dívidas são impossíveis de serem pagas e os trabalhadores se vêem obrigados a continuar sujeitados à situação de exploração ${ }^{64}$.

Alguns são submetidos a abuso físico, sexual e verbal, além de trabalharem em condições inadequadas, anti-higiênicas e perigosas. Os direitos trabalhistas $\mathrm{e}$ as regulamentações de segurança são costumeiramente ignoradas. Nesse sentido, os trabalhadores correm riscos à saúde, muitos sofrem de doenças tropicais e acidentes de trabalho ao operarem máquinas ${ }^{65}$.

Shahinian afirma ter recebido informações de que os trabalhadores normalmente são vigiados por guardas armados e recebem ameaças de violência contra eles e seus familiares, tornando impossível uma eventual fuga. Os que tentam escapar são perseguidos, feridos e alguns chegam a ser assassinados. Quando conseguem ser liberados, encontram muita dificuldade para se reintegrarem às suas comunidades e, devido à extrema pobreza e desespero por emprego, acabam aceitando novamente a situação de trabalho análogo ao de escravo ${ }^{66}$.

Nesse contexto se inseriu José Pereira Ferreira, adolescente cuja situação análoga a de escravo foi negligenciada pelo Estado brasileiro,

\footnotetext{
${ }^{64}$ SHAHINIAN, 2010, p. 8.

OIT - ORGANINZAÇÃO INTERNACIONAL DO TRABALHO. Trabalho Escravo no Brasil do Século XXI. $1^{a}$ ed., SAKAMOTO, Leonardo (Coord.). Brasil, 2006. p. 20-29.

${ }^{65}$ Em relatório da OIT, organizado por Leonardo Sakamoto, há informações de que os trabalhadores que adquirem doenças são deixados à própria sorte. Devido aos altos índices de desemprego na região, há um grande contingente de pessoas em busca de um serviço que possa prover seu sustento e de sua família. Essa grande quantidade de mão-de-obra ociosa se torna um exército de reposição. Uma pessoa doente torna-se um mero estorvo. Portanto, não são raros os relatos de pessoas que foram simplesmente mandadas embora ao ficarem doentes ou após sofrerem um acidente durante o serviço. Somado a isso estão os casos em que os maus tratos e violência perpetrados pelos empregadores geram danos irreparáveis aos trabalhadores, como mutilação e cegueira. Quando recebem indenizações dos patrões por essas violências, os valores são sempre irrisórios. A descrição da situação desses trabalhadores, bem como alguns relatos dos mesmos em relação aos danos irreparáveis sofridos estão disponíveis em: OIT - ORGANINZAÇÃO INTERNACIONAL DO TRABALHO. Trabalho Escravo no Brasil do Século XXI. $1^{\mathrm{a}}$ ed., SAKAMOTO, Leonardo (Coord.). Brasil, 2006. p. 28-31.

${ }^{66}$ SHAHINIAN, 2010, p. 8.
} 
representando um caso simbólico de "omissão" por parte do Estado nos seus deveres de proteção judicial, segurança no trabalho e garantia dos direitos humanos - em nossa opinião, seria um eufemismo afirmar que o Estado foi meramente omisso se levarmos em conta a contextualização do trabalho escravo abordada. Seu caso foi levado por organizações nãogovernamentais ao Sistema Interamericano de Proteção aos Direitos Humanos, assunto que trataremos a seguir.

\subsection{Os fatos provados do caso}

Em setembro de 1989, José Pereira Ferreira, então com 17 anos de idade, e outros 60 trabalhadores foram recrutados por "gatos" atraídos por falsas promessas e retidos contra sua vontade para trabalharem na fazenda Espírito Santo no sul do Pará, sem remuneração e em condições desumanas e ilegais ${ }^{67}$.

Em entrevista à organização Repórter Brasi1 ${ }^{68}$, José Pereira afirmou que ele e os demais trabalhadores trabalhavam com funcionários vigiandoos armados. Ao perceber que as condições de trabalho não melhorariam, José e outro trabalhador com quem fez amizade, chamado de Paraná, tentaram fugir.

Nessa tentativa, porém, foram atacados por disparos de fuzil pelos funcionários armados. Paraná não resistiu aos disparos e faleceu imediatamente. José Pereira, apesar de atingido no olho direito e na mão direita, sobreviveu após fingir-se de morto, enganando os atiradores. Os agressores deixaram os dois corpos no terreno de uma fazenda vizinha, o que permitiu que José conseguisse andar o suficiente para ser socorrido e apresentar uma denúncia contra a fazenda Espírito Santo.

\footnotetext{
${ }^{67}$ CIDH. Relatório N ${ }^{\circ}$ 95/03 sobre o caso 11.289, publicado em 24 de outubro de 2003. pars. 11 23 p. $2-4$.

68 ONG Repórter Brasil Entrevista. Disponível em: <http://reporterbrasil.org.br/2004/06/zepereira-um-sobrevivente/>. Acesso em: 2 out. 2016.
} 
Após cinco anos desse episódio, em 16 de dezembro de 1994, as organizações Centro pela Justiça e o Direito Internacional (CEJIL) ${ }^{69}$, Human Rights Watch/Americas ${ }^{70}$ e Comissão Pastoral da Terra $^{71}$ apresentaram uma petição perante a Comissão Interamericana de Direitos Humanos contra a República Federativa do Brasil alegando os fatos acima expostos.

$\mathrm{Na}$ petição apresentada à $\mathrm{CIDH}$, alegou-se que, nos fatos relacionados à José Pereira, foram violados os artigos I e XXV da Declaração Americana sobre Direitos e Obrigações do Homem, os quais estabelecem: o direito à vida, à liberdade, à segurança e integridade pessoal e o direito à proteção contra detenção arbitrária. O Estado brasileiro foi também acusado de violar os artigos $6^{\circ}, 8^{\circ}, 25$ da Convenção Americana sobre os Direitos Humanos, que referem-se à proibição de escravidão e servidão, garantias judiciais e proteção judicial.

\subsection{0 acordo}

A Comissão recebeu a denúncia em 22 de fevereiro de 1994 e, no mês seguinte, foi encaminhada para que o Estado brasileiro respondesse. Em novembro de 1995, com autorização do então presidente Fernando

\footnotetext{
${ }^{69}$ El Centro por la Justicia y el Derecho Internacional (CEJIL por sus siglas en inglés) tiene como misión contribuir al goce de los derechos humanos en el continente americano mediante un uso eficaz del Sistema Interamericano de Derechos Humanos (SIDH), y de otros mecanismos de protección internacional.

Disponível em: 〈https://www.cejil.org/es/quienes-somos-mas〉. Acesso em: 21 nov. 2016.

70 A Human Rights Watch é uma organização internacional de direitos humanos, nãogovernamental, sem fins lucrativos, contando com aproximadamente 400 membros que trabalham em diversas localidades ao redor do mundo.

Disponível em: <https://www.hrw.org/pt/sobre-human-rights-watch>. Acesso em: 21 nov. 2016.

${ }^{71}$ A Comissão Pastoral da Terra (CPT) é uma organização da Igreja Católica voltada para a defesa dos direitos humanos e da reforma agrária. "A CPT foi criada para ser um serviço à causa dos trabalhadores do campo e de ser um suporte para a sua organização".

Disponível em: 〈http://www.cptnacional.org.br/index.php/sobre-nos/historico>. Acesso em: 30 out. 2016.

A Comissão Pastoral da Terra, grande responsável por denúncias de condições de trabalho escravo violadoras de direitos humanos, havia registrado nos anos imediatamente anteriores à denúncia de José Pereira, 37 casos de fazendas onde predominava o trabalho forçado que afetavam, naquela época, 31.426 trabalhadores. Tais dados provaram perante a CIDH que a situação de José Pereira e seus companheiros não era isolada (Relatório CIDH, 2003.2).
} 
Henrique Cardoso, a CIDH realizou uma visita in loco $^{72}$ ao Brasil. Uma delegação da Comissão percorreu algumas regiões do Estado do Pará com representantes dos Ministérios de Justiça e de Relações Exteriores brasileiros. À época, tiveram acesso a depoimentos de advogados, defensores de direitos humanos, trabalhadores rurais, promotores e juízes locais a respeito das condições de trabalho análogas à escravidão e sobre o ocorrido na Fazenda Espírito Santo em especial.

Após a realização de diversas audiências e reuniões de trabalho sobre o caso em comento, em 24 de fevereiro de 1999, a CIDH aprovou um relatório $^{73}$ sobre admissibilidade e mérito, considerando o Estado responsável por violações à Declaração Americana sobre os Deveres e Direitos do Homem e à Convenção Americana de Direitos Humanos. No mesmo relatório, ofereceu recomendações ao Estado.

$\mathrm{O}$ relatório foi enviado ao Estado e, em seguida, a $\mathrm{CIDH}$ impulsionou um processo de solução amistosa, no qual as partes forneceram mais informações, celebraram reuniões de trabalho e audiências perante a Comissão, sendo a última delas realizada em 14 de outubro de 2003, ocasião em que as partes apresentaram à Comissão o acordo de solução amistosa, assinado em Brasília em 18 de setembro de $2003^{74}$.

Esse acordo foi um marco para a proteção dos Direitos Humanos no Brasil. É importante mencionar que, em 1995, o Governo Brasileiro reconheceu oficialmente a existência de trabalho em condição análoga à de escravo no país perante o Comitê de Direitos Humanos da ONU e começou a tomar medidas para erradicá-1o ${ }^{75}$. Contudo, esse reconhecimento foi em relação apenas ao contexto geral de exploração de trabalho escravo

\footnotetext{
72 Os resultados dessa investigação in loco podem ser analisadas no Relatório Sobre a Situação dos Direitos Humanos no Brasil. Aprovado pela Comissão em 29 de setembro de 1997.

Disponível em: <https://cidh.oas.org/countryrep/brazil-port/indice.htm〉. Acesso em: 23 nov. 2016

${ }^{73}$ Relatório não disponível pela CIDH.

${ }^{74}$ CIDH. Relatório No 95/03 sobre o caso 11.289, publicado em 24 de outubro de 2003.

75 Ver: BRASÍLIA. Manual de Combate ao Trabalho em Condições Análogas às de Escravo, 2011. p. 8;

SHAHINIAN, 2010, p. 4;

OIT. Combatendo o trabalho escravo contemporâneo: o exemplo do Brasil, 2010, p. 31.
} 
contemporâneo. No caso José Pereira, por outro lado, o reconhecimento foi um pouco diferente, pois não apenas reconheceu genericamente a existência de trabalho escravo, mas reconheceu a responsabilidade por aquele caso específico e pela existência de casos semelhantes perpetrados por particulares sob a negligência estatal.

Portanto, foi em 2003, no âmbito de celebração do acordo de Solução Amistosa, a primeira vez na história que o Brasil reconheceu perante uma corte internacional sua responsabilidade pelas violações de direitos humanos em um caso específico e firmou um acordo garantindo que cumpriria os compromissos nele estabelecidos ${ }^{76}$. Como afirmaram os peticionários, "tal responsabilidade foi devida pois os órgãos estaduais não foram capazes de prevenir a ocorrência de práticas graves de trabalho escravo, bem como de punir os indivíduos envolvidos nas violações alegadas"77.

O Acordo determinou algumas obrigações e recomendações ao Estado brasileiro, as quais foram divididas em: (i) Reconhecimento de Responsabilidade; (ii) Julgamento e Punição dos Responsáveis Individuais; (iii) Medidas Pecuniárias de Reparação; (iv) Medidas de Prevenção - a) modificações legislativas, b) medidas de fiscalização e repressão do trabalho escravo, c) medidas de sensibilização -; e (v) Mecanismo de Seguimento. Essas determinações passarão a ser analisadas a seguir.

\subsubsection{Medidas de Reconhecimento, Julgamento e Reparação}

\footnotetext{
76 AUDI, Patrícia. Escravagismo Impune. O Globo, Opinião Consultiva, p. 7. Publicado em 22.05.2006. Disponível em:

<https://www2.senado.leg.br/bdsf/bitstream/handle/id/400299/noticia.htm?sequence=1>. Acesso em: 03 out. 2016.

77 SANTOS, Cecília Macdowell Santos. Ativismo jurídico transnacional e o Estado: reflexões sobre os casos apresentados contra o Brasil na Comissão Interamericana de Direitos Humanos. SUR, Revista Internacional de Direitos Humanos. Vol. 4, nº 7. São Paulo. 2007.
} 
O presente tópico visa a analisar os compromissos adotados pelo Brasil no que tange às medidas que afetam diretamente a vítima do caso, o senhor José Pereira, bem como se tais compromissos foram cumpridos.

\section{a) Reconhecimento de Responsabilidade}

Conforme anteriormente mencionado, foi a primeira vez que o Estado brasileiro reconheceu sua responsabilidade por violações específicas de direitos humanos ocorridas em seu território perante uma Organização Internacional. Importante ressaltar que, a responsabilidade foi reconhecida apesar de a autoria das violações não ser atribuída a agentes do Estado. A responsabilidade tem relação com a incapacidade dos órgãos estatais na prevenção da ocorrência de trabalho escravo, bem como a incapacidade de punir os atores individuais das violações denunciadas ${ }^{78}$.

Em 18 de setembro de 2003, mesma data em que foi assinada a solução amistosa entre as partes do Caso, foi realizada a solenidade de criação da Comissão Nacional de Erradicação do Trabalho Escravo $(\text { CONATRAE })^{79}$, ocasião em que foi declarado publicamente o reconhecimento de responsabilidade pela existência de exploração de trabalho escravo no país e pelos fatos do caso José Pereira.

\section{b) Julgamento e Punicão dos Responsáveis Individuais}

Os peticionários do caso afirmaram que, em 7 de outubro de 1998 o Ministério Público denunciou cinco pessoas, quatro capangas por tentativa de homicídio e redução a condição análoga a escravo e o administrador da fazenda, Arthur Benedito Costa Machado por redução à condição análoga a escravo. Arthur foi condenado a dois anos de reclusão, porém a pena não foi executada devido à prescrição do crime. Em relação aos outros quatro réus, os peticionários alegam que fugiram e que, em 21 de outubro de 1997,

\footnotetext{
${ }^{78}$ CIDH. Relatório No 95/03 sobre o caso 11.289, publicado em 24 de outubro de 2003. par. 4.

${ }^{79}$ A CONATRAE foi criada pelo Decreto Presidencial de 31 de julho de 2003. Vamos discorrer mais sobre essa Comissão em tópicos futuros.
} 
foi prolatada decisão determinando o julgamento pelo Tribunal do Júri Federal, bem como a prisão preventiva, a qual não foi executada ${ }^{80}$.

Diante dessa incapacidade de investigar, julgar e punir no caso em comento, ao celebrar o acordo de solução amistosa, o Brasil se comprometeu a encaminhar o acordo ao Diretor Geral do Departamento da Polícia Federal para que fossem cumpridos os mandados judiciais de prisão contra os acusados pelos crimes $^{81}$. Não estão disponíveis publicamente maiores informações sobre a execução desses mandados de prisão, de modo que não foi possível averiguar se os mesmos foram cumpridos.

\section{c) Medidas Pecuniárias de Reparação}

Apenas 14 (catorze) anos após os fatos, José Pereira recebeu uma indenização do Estado pelas violações de direitos humanos contra ele perpetradas, no valor de $\mathrm{R} \$ 52.000,00$ (cinquenta e dois mil reais) a José Pereira. O pagamento dessa indenização, em 25 de agosto de 2003, eximiu o Estado de efetuar qualquer outro ressarcimento a José Pereira ${ }^{82}$. Com o dinheiro, José declarou o desejo de começar uma nova vida longe da Fazenda Espírito Santo ${ }^{83}$.

\subsubsection{Medidas de Prevenção}

Além de o Acordo de Solução Amistosa do Caso José Pereira ser um marco por ter sido a primeira vez em que o Brasil reconheceu internacionalmente sua responsabilidade por violações específicas de Direitos Humanos, ademais de ter se comprometido a estabelecer o

\footnotetext{
${ }^{80}$ CIDH. Relatório $N^{o}$ 95/03 sobre o caso 11.289, publicado em 24 de outubro de 2003. p. 21-22.

${ }^{81}$ Ibid., p. 24.7.

${ }^{82}$ Ibid., p. 8-9;

BRASIL. Lei n. 10.706 de 25 de agosto 2003. Autoriza a União a conceder indenização a José Pereira. Disponível em: <http://www.planalto.gov.br/ccivil_03/leis/2003/L10.706.htm>. Acesso em: 05 out. 2016.

${ }^{83}$ Informação concedida à entrevista realizada pela ONG Repórter Brasil em 02/06/2004 ONG Repórter Brasil Entrevista. Disponível em: <http://reporterbrasil.org.br/2004/06/ze-pereiraum-sobrevivente/>. Acesso em: 2 out. 2016.
} 
julgamento e sanção dos responsáveis pelos fatos e o pagamento de uma indenização à vítima, trata-se também de um caso em que a CIDH atuou positivamente e propôs uma série de compromissos para fiscalização e repressão do trabalho escravo, bem como de modificações legislativas e medidas de sensibilização contra esse tipo de violação de Direitos Humanos no país.

No presente tópico vamos discorrer sobre essas propostas e recomendações feitas pela Comissão Interamericana de Direitos Humanos e, no capítulo 3, veremos quais delas foram implementadas.

\section{a) Modificações Legislativas}

A CIDH, em ocasião do acordo de solução amistosa, sugeriu ao Brasil melhorar a legislação nacional de modo a enrijecer a proibição e as sanções à prática de trabalho escravo no país.

Em 11 de março de 2003, o Governo brasileiro iniciou o Plano Nacional para a Erradicação do Trabalho Escravo, elaborado pela Comissão Especial do Conselho de Defesa dos Direitos da Pessoa Humana. Esse Plano Nacional continha ações e propostas de mudanças legislativas, as quais o Brasil se comprometeu a implementar ao assinar o acordo de Solução Amistosa.

O Estado brasileiro comprometeu-se, ainda, a trabalhar em busca da determinação da competência federal para julgamento do crime de redução análoga à de escravo, a efetuar esforços para aprovação legislativa (i) do Projeto de Lei No 2130-A, de 1996; e (ii) o Substitutivo apresentado pela Deputada Zulaiê Cobbra ao projeto de Lei N 5.693 do Deputado Nelson Pellegrino, cujo texto modificaria o artigo 149 do Código Penal Brasileiro $^{84}$.

${ }^{84}$ CIDH. Relatório No 95/03 sobre o caso 11.289, publicado em 24 de outubro de 2003. par. 24.1024.12 . 
No capítulo 3 discorreremos sobre quais medidas legislativas foram, de fato, implementadas.

\section{b) Medidas de Fiscalização e de Repressão}

A gravidade do problema da prática do trabalho escravo requer a tomada de medidas imediatas, ao passo que propostas legislativas demoram um tempo considerável até serem implementadas por dependerem da atuação do Congresso Nacional. Diante disso, o Brasil firmou o compromisso para a implementação de ações de fiscalização e repressão ao trabalho escravo, sendo elas: (i) estabelecer medidas de fortalecimento do Ministério Público do Trabalho; (ii) garantir que a legislação existente seja cumprida de fato, estabelecendo multas administrativas e judiciais; (iii) tornar o Grupo Móvel, iniciativa do Ministério do Trabalho e Emprego (MTE), mais eficaz, fortalecendo sua função de resgate às pessoas encontradas em contexto de escravidão; (iv) trabalhar por maior celeridade nos procedimentos investigativos e apresentação de denúncias em face dos autores de exploração de trabalho escravo; (v) garantir o exercício do seu dever de punir perante os responsáveis por crimes de trabalho escravo, assegurando as condições necessárias ao desempenho eficaz do Poder Judiciário, bem como das entidades representativas.

Adicione-se a esses compromissos, o de revogar por atos administrativos, até o ano de 2003, o Termo de Cooperação firmado entre autoridades públicas e proprietários de fazendas, por permitir a permanência do status quo através da tolerância diante de ineficazes medidas de repressão ao trabalho escravo.

O Brasil também se comprometeu com o fortalecimento da Divisão de Repressão ao Trabalho Escravo e de Segurança dos Dignitários $(\mathrm{DTESD})^{85}$, destinando mais recursos para a adequada atuação da Polícia

\footnotetext{
${ }^{85}$ Criada no departamento da Polícia Federal por meio da Portaria-MI N ${ }^{\circ} 1.1016$, de 4 de setembro de 2002 .
} 
Federal no acompanhamento de denúncias de trabalho escravo e suas devidas fiscalizações.

Por fim, comprometeu-se a promover maior envolvimento dos Procuradores Federais nas ações de fiscalização, solicitando prioridade à questão por parte do Ministério Público Federal ${ }^{86}$.

\section{c) Medidas de Sensibilização}

O Brasil também se comprometeu a adotar medidas de sensibilização contra o trabalho escravo. No acordo de Solução Amistosa assumiu o compromisso de realizar uma campanha nacional contra a prática do trabalho escravo em outubro de 2003, com enfoque no Estado do Pará. A campanha seria baseada num plano de comunicação que contemplaria a elaboração de material informativo dirigido aos trabalhadores, a inserção do tema na mídia pela imprensa e por curtas publicitários. Estavam previstas, ainda, visitas de autoridades nas áreas de enfoque. Por fim, o Estado afirmou que iria avaliar a possibilidade de realizar seminários sobre a erradicação do trabalho escravo no Estado do Pará até o primeiro semestre de 2004, com a presença do Ministério Público Federal ${ }^{87}$.

\subsubsection{Mecanismo de Seguimento}

O Regulamento da Comissão dispõe, em seu artigo 48, que, após a publicação do relatório de solução amistosa, a CIDH poderá tomar as medidas de acompanhamento que considere oportunas, como solicitar informação às partes e realizar audiências ou reuniões para verificar o cumprimento dos acordos de solução amistosa. A CIDH solicita,

\footnotetext{
${ }^{86}$ CIDH. Relatório $\mathrm{N}^{\circ}$ 95/03 sobre o caso 11.289, publicado em 24 de outubro de 2003. par. 24.1324.16.

${ }^{87}$ Ibid., par. 24.13- 24.16.
} 
anualmente, informações às partes, nos casos em que o cumprimento ainda não tenha sido total ${ }^{88}$.

Nesse sentido, para a supervisão do cumprimento do acordo de solução amistosa do Caso José Pereira até o efetivo cumprimento de todas as suas cláusulas, as partes se responsabilizaram pelo encaminhamento de relatórios anuais sobre os avanços alcançados, e a CIDH se comprometeu a facilitar audiências para receber informações e viabilizar os pedidos de visitas in situ, caso necessário ${ }^{89}$.

Diante de tantos compromissos assumidos perante a CIDH e de um contexto de exploração de escravidão tão arraigado e dissipado pelos mais diversos setores da sociedade brasileira, buscaremos examinar, no capítulo seguinte, quais desses compromissos foram, de fato, cumpridos.

88 Questionários sobre processos de solução amistosa da CIDH. Disponível em: <http://www.cidh.org/Cuestionarios.soluciones.amistosas.po.htm\#_ftn1>. Acesso em: 11 out. 2016.

${ }^{89}$ CIDH. Relatório No 95/03 sobre o caso 11.289, publicado em 24 de outubro de 2003. par. 24.19. 


\section{CAPÍTULO 3. AVANÇOS E RETROCESSOS POLÍTICOS E JURÍDICOS POSTERIORES AO ACORDO}

O terceiro capítulo do presente trabalho tem o propósito de elucidar os avanços no enfrentamento ao trabalho escravo contemporâneo nas áreas rurais do Brasil, a partir da atuação do Sistema Interamericano de Direitos Humanos, mais especificamente do cumprimento das cláusulas do Acordo de Solução Amistosa no Caso José Pereira, bem como as medidas de prevenção recomendadas pela Comissão Interamericana, analisadas no capítulo anterior.

Apesar de o Acordo de Solução Amistosa ter sido um marco para o enfrentamento ao trabalho escravo rural no Brasil, tendo o país adotado medidas positivas, algumas delas sofreram retrocessos recentemente, que representam ameaças à incipiente evolução do enfrentamento ao trabalho escravo contemporâneo. Tais retrocessos, bem como as causas estruturais ainda inalteradas, figuraram um papel importante para convencer a Comissão a submeter à Corte Interamericana o Caso Fazenda Brasil Verde vs. Brasil, cujos fatos se assemelham ao de José Pereira. Tais retrocessos e ameaças também serão analisados nesse capítulo.

A fim de melhor alcançar o objetivo desse capítulo, o mesmo será dividido em duas partes. $\mathrm{Na}$ primeira serão elencadas as medidas alcançadas pelo Brasil, incluindo aquelas que o Estado se comprometeu especificamente no Acordo de Solução Amistosa (tópico 3.1), sendo necessário destacar que nessa primeira parte não traçaremos muitos comentários. Na segunda parte serão analisadas algumas medidas que, em nossa opinião, ameaçam o incipiente processo de enfrentamento ao trabalho escravo contemporâneo pelo Brasil (tópico 3.2). Esse estudo será feito com base, especialmente: no Relatório elaborado pela Relatora da ONU para formas contemporâneas de escravidão após sua visita ao Brasil em 2010; dois relatórios elaborados pela OIT em 2006 e 2010; e pelo 
acompanhamento dos trâmites legislativos nos sites da Câmara dos Deputados e do Senado.

\subsection{Medidas Alcançadas Pelo Brasil}

O tópico a seguir visa a analisar as modificações na legislação brasileira (tópico 3.1.1), os programas implementados para a prevenção e repressão à escravidão contemporânea (tópico 3.1.2) e as medidas de sensibilização dirigidas pelo governo (tópico 3.1.3).

\subsubsection{Modificações legislativas}

Conforme mencionado no segundo capítulo desse trabalho, dentre as propostas contidas no Acordo de Solução Amistosa do Caso José Pereira, o Brasil comprometeu-se a implementar as ações e propostas de mudanças legislativas previstas no Plano Nacional para a Erradicação do Trabalho Escravo $^{90}$.

O Plano foi elaborado pela Comissão Nacional para a Erradicação do Trabalho Escravo (CONATRAE) e lançado em 11 de março de 2003 pelo ex-Presidente Luiz Inácio Lula da Silva em solenidade no Palácio do Planalto e reúne 76 medidas $^{91}$, cujo objetivo é combater o trabalho escravo por meio de ações de prevenção, repressão e monitoramento das diversas intervenções do governo. As metas estabelecidas têm como responsáveis diversos órgãos dos poderes Executivo, Legislativo e Judiciário, bem como

\footnotetext{
${ }^{90} \mathrm{O}$ documento oficial do Plano Nacional para Erradicação do Trabalho Escravo. Disponível em: <http://trabalho.gov.br/images/Documentos/trabalhoescravo/planonacional2003portugues.pdf>. Acesso em: 02 nov. 2016.

${ }^{91}$ As medidas do Plano são divididas em Ações Gerais, Melhorias na Estrutura Administrativa do grupo de Fiscalização Móvel, da Ação Policial, do Ministério Pública Federal e do Ministério Público do Trabalho, Ações Específicas de Promoção da Cidadania e Combate a Impunidade e Ações Específicas de Conscientização, Capacitação e Sensibilização.
} 
entidades da sociedade civil brasileira e a Organização Internacional do Trabalho ${ }^{92}$.

Segundo a avaliação da OIT:

$68,41 \%$ das metas estipuladas no $1^{\circ}$ Plano Nacional para a Erradicação do Trabalho Escravo foram alcançadas total ou parcialmente. Os avanços ocorreram, sobretudo, na sensibilização e capacitação dos atores sociais envolvidos no combate ao trabalho escravo e na conscientização dos trabalhadores sobre seus direitos. A mesma análise aponta que os menores avanços envolveram as medidas voltadas à diminuição da impunidade dos empregadores condenados pela prática de trabalho escravo e à garantia de emprego e reforma agrária nas regiões fornecedoras de mão-de-obra escrava ${ }^{93}$.

A atuação da CONATRAE resultou na criação do $2^{\circ}$ Plano para Erradicação do Trabalho Escravo, lançado em 2008, concentrando esforços nessas duas áreas que tiveram menos avanços. O novo documento apresenta 66 propostas divididas em ações gerais, enfrentamento e repressão, reinserção e prevenção, informação e capacitação, e repressão econômica. A primeira avaliação desse segundo plano foi feita no final de 2010 pela Secretaria de Direitos Humanos, a qual afirmou que mais de 50\% das metas foram alcançadas total ou parcialmente. Para as ações de prevenção e reinserção foram destacadas 16 iniciativas ${ }^{94}$.

Dentre as diversas mudanças legislativas recomendadas pelo Plano Nacional, destaca-se a necessidade de aprovação do Projeto de Lei (PL) $\mathrm{N}^{\circ}$ 2.667/2003, que inclui na Lei dos Crimes Hediondos (Lei № 8072/1990) o crime de redução de alguém à condição análoga a de escravo ou aliciamento de trabalhadores de um local para outro do território nacional e altera as respectivas penas, acrescentando dispositivos à Lei de Crimes

\footnotetext{
${ }^{92}$ OIT - ORGANINZAÇÃO INTERNACIONAL DO TRABALHO. Trabalho Escravo no Brasil do Século XXI. $1^{\text {a }}$ ed., SAKAMOTO, Leonardo (Coord.). Brasil, 2006. p. 97.

${ }^{93}$ OIT. Combatendo o trabalho escravo contemporâneo: o exemplo do Brasil, 2010, p. 181-182. Para informações mais detalhadas sobre a análise do Plano, ver: OIT - ORGANINZAÇÃO INTERNACIONAL DO TRABALHO. Trabalho Escravo no Brasil do Século XXI. $1^{\mathrm{a}}$ ed., SAKAMOTO, Leonardo (Coord.). Brasil, 2006.

${ }^{94}$ SENADO. "Planos brasileiros de erradicação: história dos planos brasileiros de erradicação do trabalho escravo". Jornal do Senado. Brasília, ano 2, nº 7. Maio de 2011. Disponível em: <https://www.senado.gov.br/noticias/Jornal/emdiscussao/trabalho-escravo/combate-ao-trabalhoescravo/planos-brasileiros-de-erradicacao.aspx>. Acesso em: 03 nov. 2016.
} 
Hediondos. Contudo, passados treze anos de trâmite, o Projeto de Lei ainda não foi aprovado. Segundo o acompanhamento feito pelo site da Câmara dos Deputados ${ }^{95}$, o PL está sujeito à apreciação do Plenário em regime de prioridade, apensado ao PL 5016/2005, o qual encontra-se aguardando parecer do Relator na Comissão de Trabalho, de Administração e Serviço Público (CTASP). Portanto, as penas continuam fixadas de dois a oito anos, sendo, em nosso entender, desproporcional à gravidade do crime.

Outra proposta de mudança na legislação brasileira contida no Plano Nacional, é a alteração do parágrafo $4^{\circ}$ do artigo 18 do Código Penal e uma nova redação da lei $N^{\circ} 5.889 / 1973$ para determinar maior regulamentação nas condições de trabalhado rural. Em relação a essa proposta, foi elaborado o Projeto de Lei $\mathrm{N}^{\circ}$ 1.985/2003, que visa a punição dos empregadores rurais por violações trabalhistas. Todavia, segundo acompanhamento feito pelo site da Câmara dos Deputados, tal Projeto de Lei encontra-se arquivado ${ }^{96}$.

O Plano ainda previa a aprovação da Emenda à Constituição (PEC) $\mathrm{N}^{\circ}$ 438/2001, que altera o artigo 243 da Constituição e propõe a expropriação de terras nas quais sejam achados trabalhadores em condições análogas a de escravo. Após mais de uma década de tramitação, a PEC foi aprovada em 5 de junho de 2014, dando origem à Emenda Constitucional $\mathrm{n}^{\circ} 81 / 2014^{97}$, com a seguinte redação:

Art. $1^{\circ} \mathrm{O}$ art. 243 da Constituição Federal passa a vigorar com a seguinte redação:

Art. 243. As propriedades rurais e urbanas de qualquer região do País onde forem localizadas culturas ilegais de plantas psicotrópicas ou a exploração de trabalho escravo na forma da lei serão expropriadas e destinadas à reforma agrária e a

\footnotetext{
95 Para acompanhar mais detalhadamente a tramitação do projeto. Disponível em: $<$ http://www.camara.gov.br/proposicoesWeb/fichadetramitacao?idProposicao=146837>. Acesso em: 03 nov. 2016.

${ }^{6}$ Para acompanhar mais detalhadamente o Projeto de Lei ${ }^{\circ}$ 1985/2003, ver: Disponível em: $<$ http://www.camara.gov.br/proposicoesWeb/fichadetramitacao?idProposicao=133355>. Acesso em: 03 nov. 2016.

97 A Emenda Constitucional N 81/2014. Disponível em: <http://www.planalto.gov.br/ccivil_03/Constituicao/Emendas/Emc/emc81.htm>. Acesso em: 03 nov. 2016.
} 
programas de habitação popular, sem qualquer indenização ao proprietário e sem prejuízo de outras sanções previstas em lei, observado, no que couber, o disposto no art. $5^{\circ}$.

Parágrafo único. Todo e qualquer bem de valor econômico apreendido em decorrência do tráfico ilícito de entorpecentes e drogas afins e da exploração de trabalho escravo será confiscado e reverterá a fundo especial com destinação específica, na forma da lei. (NR) (Grifei)

Note-se que foi inserido o termo "na forma da lei", de modo que a Emenda necessita de regulamentação sobre a definição de "trabalho escravo" para ser aplicada. Atualmente está tramitando o Projeto de Lei $\mathrm{N}^{\circ}$ 432/2013 do Senado, que visa à alteração da definição de trabalho escravo. A aprovação dessa EC possui um significativo potencial em relação ao enfrentamento ao trabalho escravo. Contudo, existem questões bastante polêmicas em relação a esse PL que visa a regulamentar a EC, motivo pelo qual trataremos dele de forma mais crítica no tópico 3.2.1 desse capítulo.

Para finalizar a análise das propostas legislativas contidas no Plano Nacional, é válido destacar o Projeto de Lei $\mathrm{N}^{\circ}$ 2.022/1996 sobre as vedações à formalização de contratos e licitações entre órgãos do poder público e empresas que se utilizem, mesmo que indiretamente, de trabalho escravo. Esse Projeto foi apensado ao PL 1292/1995 ${ }^{98}$, que até o momento aguarda parecer do Relator na Comissão de Constituição e Justiça e de Cidadania (CCJC).

Além das supracitadas propostas, o Estado se comprometeu a viabilizar a aprovação do Projeto de Lei N²130-A/1996, que visa alterar o artigo 21 da Lei $\mathrm{N}^{\circ} 8.884 / 1994$, que torna o Conselho Administrativo de Defesa Econômica (CADE) numa autarquia e determina como infração contra a ordem econômica, a utilização de fraudes ou meios ilegítimos para redução de custos na produção (como o descumprimento da legislação

\footnotetext{
98 O Projeto de Lei № 1292/1995 visa a alterar a lei $n^{\circ} 8.666 / 1993$, que regulamenta o art. 37, inciso XXI, da Constituição Federal, institui normas para licitações e contratos da Administração Pública e dá outras providências. Disponível em: <http://www.camara.gov.br/proposicoesWeb/fichadetramitacao?idProposicao=16526\&ord=1>. Acesso em: 03 nov. 2016.
} 
trabalhista e garantias fundamentais), além da exploração de trabalho infantil e trabalho escravo. Todavia, o Projeto de Lei foi arquivado em 31 de janeiro de $2007^{99}$.

O Estado se comprometeu, ainda, a também viabilizar a aprovação do Substitutivo apresentado pela Deputada Zulaiê Cobra ao Projeto de Lei No 5.693/2001. Este PL pretende modificar o artigo 149 do Código Penal Brasileiro, visando a ampliar a sua abrangência e a pena prevista para o crime de redução de alguém à condição análoga à de escravo (a pena seria de 4 a 8 anos ao invés da pena atual de 2 a 8 anos). Entretanto, o PL N ${ }^{\circ}$ $5.693 / 2001$ foi declarado prejudicado, face à aprovação do PL N ${ }^{o}$ 7429/2002 e, portanto, foi arquivado. O PL No 7429/2002 foi transformado na Lei Ordinária $\mathrm{N}^{\circ}$ 10.803/2003, a qual alterou o Art. 149 do Código Penal, estabelecendo as hipóteses de configuração do tipo, mas mantendo a pena de 2 a 8 anos. Essa alteração do Art. 149 do CP representou um primeiro passo para o enfrentamento ao trabalho escravo contemporâneo, mas era esperado o estabelecimento de uma pena maior, na forma do Substitutivo ao PL $N^{\circ} 5693 / 2001$, assim como conceituações mais claras e específicas.

A Relatora especial da ONU, Gulnara Shahinian, no Relatório sobre a visita ao Brasil, recomendou a adoção de uma definição mais clara de trabalho escravo. Recomendou também que as modificações legislativas fossem levadas adiante a fim de assegurar que a punição seja proporcional ao crime, de modo a evitar reincidências. Em sua opinião, a pena mínima para o crime de submissão de alguém a condição análoga a de escravo deveria ser de cinco anos. Portanto, considera que, não obstante os avanços na alteração do art. 149 do $\mathrm{CP}$, ainda há necessidade de discussão quanto à pena $^{100}$.

\footnotetext{
99 Para mais informações sobre o Projeto de Lei $\mathrm{N}^{\circ}$ 2.130-A/1996: Disponível em: $\langle$ http://www.camara.gov.br/proposicoesWeb/fichadetramitacao?idProposicao=17677>. Acesso em: 03 nov. 2016.

${ }^{100}$ SHAHINIAN, 2010, p. 102-103.
} 
Por fim, ainda em relação às mudanças legislativas, o Estado brasileiro, com o intuito de evitar a impunidade no país, comprometeu-se a defender a determinação da competência federal para o julgamento do crime de redução análoga à de escravo. Não obstante nenhuma medida legislativa tenha sido adotada nesse sentido, há precedentes do Supremo Tribunal Federal ${ }^{101}$ determinando a competência da Justiça Federal em casos de trabalho em condição análoga a de escravo. Além desses precedentes, e Emenda Constitucional $\mathrm{N}^{\circ}$ 45/2004 incluiu o parágrafo quinto ao Art. 109 da $\mathrm{CF}^{102}$, inserindo no ordenamento jurídico nacional o Incidente de Deslocamento de Competência. Trata-se de um importante instrumento que permite conferir aos juízes federais a competência para processar e julgar as causas relativas a graves violações de direitos humanos.

Shahinian considera ser clara a necessidade de se determinar a Justiça Federal como competente para investigar e julgar casos de trabalho escravo. Ressalta que, apesar de o Supremo Tribunal Federal ter decidido em Recurso Extraordinário pela competência federal, é importante que tal decisão seja incorporada à lei, de modo a conferir segurança jurídica. Acrescenta que o Governo deve cumprir integralmente as recomendações feitas pelo Comitê de Direitos Humanos de submeter todos os casos de graves violações de direitos humanos à Justiça Federal ${ }^{103}$. Tendo em vista a existência do Incidente de Deslocamento de Competência, a fim de cumprir a recomendação da ONU, é necessário que esse importante instrumento seja utilizado de fato em todos os casos em que se constatem sérias violações de Direitos Humanos.

\footnotetext{
101 Trata-se das decisões proferidas no Recurso Extraordinário $n^{\circ} 459.510$ e no Recurso Extraordinário $\mathrm{N}^{\circ} 398041$

102 Art. 109 CRFB/1988: Aos juízes federais compete processar e julgar:

$\S 5^{\circ}$ Nas hipóteses de grave violação de direitos humanos, o Procurador-Geral da República, com a finalidade de assegurar o cumprimento de obrigações decorrentes de tratados internacionais de direitos humanos dos quais o Brasil seja parte, poderá suscitar, perante o Superior Tribunal de Justiça, em qualquer fase do inquérito ou processo, incidente de deslocamento de competência para a Justiça Federal. (Incluído pela Emenda Constitucional $n^{\circ} 45$, de 2004).

103 SHAHINIAN, 2010, p. 18.
} 
Diante do exposto nesse tópico, fica clara uma grande dificuldade de se adotarem medidas legislativas no que tange ao "trabalho escravo" no Congresso Nacional. É possível perceber que os trâmites legislativos se prolongam por muitos anos e sempre encontram grande resistência de alguns setores. A aprovação da EC n. 81 é um exemplo dessa resistência, tendo em vista que a mesma demorou mais de dez anos para ser aprovada e, ainda assim, só foi possível a aprovação mediante a discussão de um Projeto de Lei que visa a restringir o conceito já estabelecido de trabalho análogo ao de escravo, conforme veremos em tópico específico.

\subsubsection{Medidas de Repressão e Prevenção}

Não obstante grande parte das propostas de modificações legislativas não tenham avançado suficientemente, o país tem criado novos programas para o enfrentamento ao trabalho escravo contemporâneo. Exemplos dessas medidas incluem, conforme relatório da OIT Brasil: (i) a criação da CONATRAE (Comissão Nacional para a Erradicação do Trabalho Escravo), com a designação de formular e monitorar o Primeiro e o Segundo Planos Nacionais de Prevenção e Erradicação do Trabalho Escravo; (ii) a criação do Grupo Especial Móvel de Fiscalização do Ministério do Trabalho e Emprego (GEFM); (iii) a criação de varas da justiça do trabalho nas áreas mais afetadas pelo trabalho escravo; (iv) a criação do "Cadastro de Empregados Flagrados na Exploração de Trabalho e Condições Análogas a de Escravo" por parte do Governo Federal; (v) e o Pacto Nacional pela Erradicação do Trabalho Escravo ${ }^{104}$. Explicaremos cada um deles nesse tópico.

\section{(i) CONATRAE}

${ }^{104}$ OIT. Combatendo o trabalho escravo contemporâneo: o exemplo do Brasil, 2010, p. 2010. 
A CONATRAE ${ }^{105}$ é formada por representantes dos poderes Executivo, Legislativo e Judiciário e por organizações da sociedade civil. Seu objetivo é fiscalizar o cumprimento das metas previstas nos Planos Nacionais para a Erradicação do Trabalho Escravo, as quais contemplam o conjunto de ações proposto pelo Governo Brasileiro no Acordo de Solução Amistosa do Caso José Pereira.

A relatora especial da ONU afirmou em seu relatório que o Brasil evoluiu quanto às medidas de prevenção e repressão ao trabalho escravo, pois, além de ter criado novos instrumentos para alcançar suas metas, deu continuidade e fortaleceu instrumentos que já existiam, como o Grupo Especial de Fiscalização Móvel.

\section{(ii) Grupo de Fiscalização Móvel}

A articulação entre os três Poderes do Estado e o Ministério Público, tem contribuído de várias formas para a repressão do trabalho escravo. Dentre essas formas, o instrumento mais destacado é o Grupo Especial de Fiscalização Móvel (GEFM) do Ministério do Trabalho e Emprego (MTE).

O GEFM foi criado em 1995, sendo formado por equipes especializadas na fiscalização do trabalho escravo, com o objetivo de melhor investigar as condições de trabalho forçado ao redor do Brasil. Essas equipes são integradas por auditores fiscais do trabalho, policiais federais, procuradores do trabalho e policiais rodoviários federais. Segundo

\footnotetext{
105 A CONATRAE é vinculada à Secretaria de Direitos Humanos da Presidência da República. Além de coordenar e avaliar a implementação das ações previstas no Plano Nacional para a Erradicação do Trabalho Escravo, também compete a ela acompanhar a tramitação de projetos de lei no Congresso Nacional e avaliar a proposição de estudos e pesquisas sobre o trabalho escravo no país. Disponível em: <http://www.sdh.gov.br/assuntos/conatrae/programas/comissao-nacionalpara-a-erradicacao-do-trabalho-escravo>. Acesso em: 04 nov. 2016.

SHAHINIAN, 2010, p. 9.

Shahinian observa que os estados do Pará, Maranhão, Mato Grosso, Tocantins e Bahia estabeleceram suas próprias comissões, chamadas de COETRAES (Comissão Estadual para Erradicação do Trabalho Escravo). Ressalta que, dos 26 estados, apenas 6 têm programas estaduais para o combate ao trabalho escravo e afirma que deveria ser obrigatório que cada estado tivesse um programa. Observa, ainda, que os impactos dos programas implementados pelos Estados são muito diferentes e deveriam ser organizados de maneira coerente. As disparidades entre os Estados podem prejudicar a eficácia dos projetos e frustrar as iniciativas positivas.
} 
a OIT, GEFM exerce o papel de investigar as denúncias de trabalho escravo in loco, resgatar os trabalhadores explorados e autuar os proprietários das fazendas exploradoras ${ }^{106}$.

As denúncias de trabalho escravo são feitas, geralmente, por vítimas de trabalhado escravo que escaparam ou por aqueles liberados após a prestação de serviço temporário. A Comissão Pastoral da Terra é uma das principais organizaçõos de auxílio às vítimas, sendo frequentemente procuradas para apresentação de denúncias Além da CPT, a Polícia Federal, os sindicatos de trabalhadores rurais e as cooperativas de trabalhadores também costumam receber as denúncias das vítimas, que são encaminhadas ao MTE, em Brasília, e às Delegacias Regionais do Trabalho (DRT) nos $\operatorname{estados}^{107}$.

O GEFM costuma realizar vistorias de surpresa nas fazendas ${ }^{108}$. Para evitar a corrupção, agilizar o trabalho e garantir o sucesso das operações, o GEFM está centralizado em Brasília e as fiscalizações são planejadas em sigilo. Se as condições encontradas na fazenda inspecionada forem muito graves, se o proprietário se recusar a pagar a multa ou criar qualquer empecilho ao desempenho do GEFM, o Ministério Público do Trabalho pode acionar a Justiça do Trabalho e solicitar o congelamento das contas bancárias dos sócios do empreendimento agrícola fiscalizado e, ainda, a prisão dos envolvidos.

A atuação do GEFM tem sido de extrema importância para, além de resgatar diversos trabalhadores, conscientizá-los sobre seus direitos e fazer com que os empregadores conhecessem de forma clara suas obrigações.

\footnotetext{
${ }^{106}$ OIT. Combatendo o trabalho escravo contemporâneo: o exemplo do Brasil, 2010, p. 128.

107 OIT. Combatendo o trabalho escravo contemporâneo: o exemplo do Brasil, 2010, p. 128.

108 Segundo relatório da OIT, endividamento, presença de vigilância armada, evidências de maustratos ou condições degradantes de trabalho, geralmente associadas à falta de higiene no local de moradia dos trabalhadores, falta de segurança no trabalho, salários muito baixos e jornadas extenuantes, são alguns aspectos que permitem aos agentes do GEFM constatar a existência de trabalho escravo.
} 
Isso enfraqueceu a lógica da impunidade e do lucro fácil presente em algumas regiões do país ${ }^{109}$.

Shahinian afirma em seu relatório que, em 1995, o Grupo havia inspecionado 77 fazendas, das quais foram libertados 84 trabalhadores. Já em 2010, o Grupo inspecionou mais de 2.500 fazendas e libertou mais de 37 mil trabalhadores em condições análogas a de escravos ${ }^{110}$.

Todavia, grandes riscos e dificuldades marcam a atuação do GEFM, como as constantes ameaças e ataques oriundos dos fazendeiros, os quais dominam os poderes públicos locais e dificultam a realização das fiscalizações. Dentre esses ataques, é importante destacar o ocorrido em 28/01/2004, que resultou na morte de três auditores fiscais do MTE e do motorista da equipe. Eles apuravam uma denúncia em Unaí, MG, quando foram emboscados e assassinados com tiros na cabeça. A Polícia Federal constatou, a partir de suas investigações, que os fazendeiros da região foram os mandantes do crime, os quais não foram jamais julgados ou presos ${ }^{111}$.

Segundo a OIT, além das ameaças, o GEFM também encontra dificuldades referentes à ausência de infra-estrutura adequada (como carros e equipamentos de comunicação apropriados) à apuração mais ágil de denúncias em locais isolados. Shahinian ressalta ainda uma lacuna no funcionamento do Grupo Móvel. A relatora destaca que é mais fácil aos inspetores imporem sanções administrativas por meio de multas do que a Polícia Federal recolher elementos de prova criminal. A Polícia Federal se justifica alegando que a legislação sobre trabalho escravo é inadequada na

\footnotetext{
109 VIANA, Marco Túlio. “Trabalho Escravo e 'Lista Suja': um modo original de remover uma mancha" In: Possibilidades Jurídicas de Combate à Escravidão Contemporânea, Brasília: Organização Internacional do Trabalho (OIT), 2007. p. 57.

110 SHAHINIAN, 2010, p. 8.

${ }^{111} \mathrm{O}$ assassinato dos membros do GEFM, fato conhecido como Chacina de Unaí, foi divulgado em diversos meios de comunicação.

WROBLESKI, Stefano. Dez anos depois, cinco acusados pela Chacina de Unaí ainda não foram julgados. 28.01.2014. Repórter Brasil. Disponível em: <http://reporterbrasil.org.br/tags/chacinade-unai/>. Acesso em: 21 nov. 2016.

MENDES, Carlos. Grupo de fiscais do trabalho é atacado por pistoleiros do Pará. 20.05.2016. Estadão. Disponível em: <http://politica.estadao.com.br/noticias/geral,grupo-de-fiscais-dotrabalho-e-atacado-por-pistoleiros-no-para,10000052523>. Acesso em: 21 nov. 2016.
} 
identificação de critérios criminais claros de caracterização de trabalho escravo $^{112}$.

\section{(iii) Tribunais Permanentes e Móveis}

Além de continuar o trabalho do Grupo Móvel, após 2003 o governo brasileiro também deu continuidade aos Tribunais Permanentes e Móveis, os quais foram instituídos em 2002 para apoiar a atuação do GEFM. Os Tribunais Móveis podem congelar as contas bancárias e apreender bens dos proprietários das fazendas, aplicar multas imediatas, tornando mais difícil a não cooperação dos proprietários rurais e facilitando os pagamentos ${ }^{113}$.

Em 2004, determinou-se uma verba específica no orçamento da Justiça do Trabalho para o combate ao trabalho escravo, estruturando e dando suporte às varas itinerantes da Justiça do Trabalho ${ }^{114}$.

\section{(iv) Cadastro de Empregados Flagrados na Exploração de Trabalho e} Condições Análogas a de Escravo ("Lista Suja")

Além do GEFM e da Justiça Itinerante, a "Lista Suja" tem sido um importante instrumento para enfrentar a questão do trabalho escravo. O MTE e a Secretaria de Direitos Humanos da Presidência da República são os responsáveis por essa Lista, que foi instituída pela Portaria ${ }^{\circ}$ 540/2004 do $\mathrm{MTE}^{115}$. Ela consiste no cadastro de pessoas físicas e jurídicas autuadas por exploração de trabalho escravo e é semestralmente atualizada.

A inclusão do nome do empregador na Lista Suja, se dá mediante flagrante de exploração de trabalho análogo ao de escravo. Após terem garantido o direito de defesa administrativa em duas instâncias, os

\footnotetext{
112 SHAHINIAN, 2010, p. 11.

113 SHAHINIAN, 2010, p. 8.

114 VIANA, 2007, p. 58.

115 Para acessar a redação da Portaria 540/2004 do MTE, Ver: Disponível em: <http://trabalho.gov.br/images/Documentos/trabalhoescravo/BRA77204.pdf>. Acesso em: 07 nov. 2016.
} 
empregadores são listados e seus nomes continuam em monitoramento na Lista por dois anos. Se, ao longo desse período, o empregador autuado não reincidir no crime, pagar todas as multas resultantes da fiscalização e quitar todos os débitos trabalhistas e previdenciários, seu nome poderá ser excluído da Lista ${ }^{116}$.

A Lista, per se, não determina qualquer punição ou restrição legal às empresas. Ela funciona mais como um mecanismo de transparência, pois disponibiliza informação sobre os que insistem em adotar essa nefasta prática $^{117}$.

É importante mencionar também a Portaria ${ }^{\circ} 1.150$ do Ministério da Integração Nacional (MIN) ${ }^{118}$, a qual recomenda que os agentes financeiros, sob sua supervisão, se abstenham de fornecer "financiamentos ou qualquer tipo de assistência com recursos" a empregadores inseridos na Lista. Não obstante não haja sanções aos bancos que concederem crédito aos integrantes da Lista Suja, a recomendação da Portaria tem sido respeitada pelas referidas instituições ${ }^{119}$.

Leonardo Sakamoto, representante da ONG Repórter Brasil, ressalta que, além da restrição de crédito, a divulgação da Lista Suja “criou uma base de trabalho para as instituições governamentais e nãogovernamentais que atuam na repressão à escravidão fomentando a

\footnotetext{
116 VIANA, Op. cit.

CHAGAS, Daniel de Matos Sampaio. O Ministério do Trabalho e Emprego e os Subsídios para Defesa Judicial da União nas Ações Relativas ao Cadastro de Empregadores do Trabalho Escravo. In: Possibilidades Jurídicas de Combate à Escravidão Contemporânea, Brasília: Organização Internacional do Trabalho (OIT), 2007.

OIT. Combatendo o trabalho escravo contemporâneo: o exemplo do Brasil, 2010, p. 146-147.

O mesmo também está disposto na redação dos dois primeiros artigos da Portaria 540/2004:

Art. $1^{\circ}$ Criar, no âmbito do Ministério do Trabalho e Emprego - MTE, o Cadastro de Empregadores que tenham mantido trabalhadores em condições análogas à de escravo.

Art. $\mathbf{2}^{\mathbf{0}}$ A inclusão do nome do infrator no Cadastro ocorrerá após decisão administrativa final relativa ao auto de infração lavrado em decorrência de ação fiscal em que tenha havido a identificação de trabalhadores submetidos a condições análogas à de escravo.

${ }^{117}$ Esclarecimento dado por Adriana Charoux, da campanha Amazônia do Greenpeace. Disponível em: <http://m.greenpeace.org/brasil/pt/high/Noticias/Lista-Suja-do-Trabalho-Escravo-continuabloqueada-pelo-STF/>. Acesso em: 07 nov. 2016.

118 Para acessar a redação da Portaria $n^{\circ} 1.150 / 2003$ do MIN, ver: Disponível em: <http://www.mi.gov.br/c/document_library/get_file?uuid=b9f0a700-687a-47e3-9c1c4d418f9e6cf8\&groupId=407753>. Acesso em: 07 nov. 2016.

119 OIT. Combatendo o trabalho escravo contemporâneo: o exemplo do Brasil, 2010, p. 149-151
} 
criação de outros mecanismos". Esses mecanismos são "a identificação da cadeia dominial das propriedades rurais" e a identificação da "cadeia produtiva do trabalho escravo". Com base nas informações colhidas por esses mecanismos, o setor empresarial, organizado pelo Instituto Ethos, lançou o Pacto Nacional pela Erradicação do Trabalho Escravo ${ }^{120}$. Portanto, esse instrumento é útil para as empresas fiscalizarem todo o processo produtivo, para os bancos sancionarem os que exploram trabalho escravo deixando de conceder crédito e, ainda, para os consumidores saberem se os produtos que consomem são provenientes de mão-de-obra análoga à escrava.

Apesar de a Lista Suja ser considerada um dos instrumentos mais eficazes para a erradicação do trabalho escravo contemporâneo, a mesma foi suspensa em dezembro de 2014 por uma Medida Liminar conferida pelo então Presidente do STF. Abordaremos a suspensão da Lista Suja e a ameaça que tal medida representa no tópico 3.2 desse trabalho.

\section{(v) Pacto Nacional pela Erradicação do Trabalho Escravo}

Segundo a OIT Brasil, as ações do Poder Público são mensuradas pelo cumprimento dos Planos Nacionais para a Erradicação do Trabalho Escravo, enquanto as ações do setor privado são controladas pelo Pacto Nacional. Conforme mencionado no item anterior, o Pacto Nacional foi organizado e mediado pelo Instituo Ethos, em parceria com a ONG Repórter Brasil e a OIT, e assinado em 19.05.2005 em solenidade no auditório da Procuradoria Geral da República em Brasília, DF.

A OIT Brasil esclarece que o Pacto Nacional se trata de:

Um compromisso voluntário assumido por cerca de 200 empresas visando dignificar e modernizar as relações de trabalho em suas cadeias produtivas (...). O Pacto Nacional colocou na agenda dos empresários e da sociedade brasileira

${ }^{120}$ OIT - ORGANINZAÇÃO INTERNACIONAL DO TRABALHO. Trabalho Escravo no Brasil do Século XXI. $1^{\text {a }}$ ed., SAKAMOTO, Leonardo (Coord.). Brasil, 2006. p. 62-64. 
esforços para dignificar, formalizar e modernizar as relações de trabalho em todos os seguimentos econômicos"121.

Segundo o Instituto ETHOS, o compromisso assumido pelas empresas brasileiras e multinacionais ao assinarem o Pacto Nacional é o de "não negociar com quem explorar o trabalho escravo". Os signatários se comprometem a cumprir 10 compromissos ${ }^{122}$, que são linhas de ação que devem ser desenvolvidas pelas empresas para o enfrentamento ao trabalho escravo em suas cadeias produtivas. O cumprimento dos compromissos é anualmente monitorado e, dependendo do nível de comprometimento de um signatário, ele é mantido, suspenso ou excluído do Pacto ${ }^{123}$.

Dados mais atualizados disponíveis no site do ETHOS, informam que, no início de 2014, o Pacto contava com mais de 400 signatários, que juntos representavam mais de $35 \%$ do PIB brasileiro ${ }^{124}$. Com o objetivo de fortalecer, ampliar e monitorar as ações realizadas no âmbito do Pacto Nacional, em maio de 2014 foi lançado o Instituto Pacto Nacional pela Erradicação do Trabalho Escravo (InPACTO) ${ }^{125}$.

Ainda segundo a OIT, foram inúmeros os casos de empresas que cortaram relações comerciais com fornecedores após a assinatura do Pacto Nacional. Sakamoto informa que uma das determinações do Pacto é a suspensão dos contratos de fornecimento provenientes de fazendas que se utilizam de mão de obra análoga à escrava. Muitos signatários do Pacto, além de terem suspendido relações comerciais como citado acima, também

${ }^{121}$ OIT. Combatendo o trabalho escravo contemporâneo: o exemplo do Brasil, 2010, p. 157.

122 Os compromissos estão dispostos no Termo de Associação ao Impacto e Compromisso. Disponível em: <http://www.inpacto.org.br/documentos/compromisso/>. Acesso em: 07 nov. 2016.

123 Disponível em: <https://www3.ethos.org.br/conteudo/projetos/apoiados/pacto-nacional-pelaerradicacao-do-trabalho-escravo/\#.WCEmXvorLIU>. Acesso em: 07 nov. 2016.

${ }^{124}$ Ibid., Acesso em: 07 nov. 2016.

125 Disponível em: <http://www.inpacto.org.br/inpacto-2/quem-somos/>. Acesso em: 07 nov. 2016. 
passaram a adotar diversas medidas a fim de manter fora de sua cadeia produtiva praticantes desse crime ${ }^{126}$.

\subsubsection{Medidas de Sensibilização}

No que tange às medidas de sensibilização contra o trabalho escravo, o Estado brasileiro se comprometeu a realizar uma campanha nacional de conscientização contra essa prática, com enfoque especial no estado do Pará. Nesse sentido, em outubro de 2003 foi lançada a Campanha Nacional de Prevenção ao Trabalho Escravo, coordenada pela OIT-Brasil, com apoio do Governo e da CONATRAE, e desenvolvida a partir de contribuições voluntárias de agências de publicidade e comunicação. Por meio dessa campanha são desenvolvidos banners, vídeos publicitários, spots de rádio e cartilhas de alta qualidade, que esclarecem os trabalhadores sobre a possibilidade de serem submetidos à exploração. Foram produzidos, também, cinco anúncios de página dupla, um filme de um minuto para TV e outdoors. O material dessa campanha foi exposto nos principais aeroportos nacionais do país e também foi divulgado nas diferentes mídias (revistas, jornais, emissoras de TV e sites) ${ }^{127}$.

Conforme informações disponibilizadas pela OIT-Brasil, a Campanha Nacional apresentou três etapas. A primeira delas foi realizada em 2003, tendo como objetivo a sensibilização da opinião pública, ou seja, de convencê-la da realidade do trabalho escravo no país e de esclarecer suas circunstâncias. A primeira ação praticada foi a criação da logomarca da campanha, qual seja, "um símbolo de proibido em cima de uma mão acorrentada com a assinatura 'Trabalho Escravo-Vamos abolir de vez essa vergonha". Todas as peças da campanha têm essa logomarca impressa, junto ao símbolo da OIT $^{128}$.

\footnotetext{
${ }^{126}$ OIT - ORGANINZAÇÃO INTERNACIONAL DO TRABALHO. Trabalho Escravo no Brasil do Século XXI. $1^{\text {a }}$ ed., SAKAMOTO, Leonardo (Coord.). Brasil, 2006. p. 125.

${ }^{127}$ OIT. Combatendo o trabalho escravo contemporâneo: o exemplo do Brasil, 2010, p. 166-167.

${ }^{128}$ Ibid., p. 166-167.
} 
A segunda fase da Campanha foi lançada em dezembro de 2005 e o material produzido foi direcionado especialmente aos potenciais trabalhadores passíveis de submissão ao trabalho escravo. Para que esse material fosse adequada e estrategicamente distribuído, contou-se com apoio de parceiros-chave, como a Comissão Pastoral da Terra, a Confederação Nacional de Trabalhadores na Agricultura e a Polícia Rodoviária Federal. Essa campanha fornecia informações sobre as formas mais comuns utilizadas pelos "gatos" para aliciarem trabalhadores, as características do trabalho escravo, a quais instituições recorrer, os direitos trabalhistas, bem como seus endereços e telefones nas principais regiões de aliciamento e prática de trabalho escravo ${ }^{129}$.

Por fim, a terceira fase foi lançada em 2007. O principal objetivo dessa etapa era lembrar ao público que, não obstante os esforços e progressos no combate ao trabalho escravo, o problema persiste. Segundo a OIT-Brasil:

Ao folhear as revistas com o anúncio, o leitor se deparava com duas mãos algemadas. Essas algemas também unem as páginas da revista (...). Ao forçar a revista para abri-la, os elos se romperiam e o leitor veria o título: 'Infelizmente, acabar com o trabalho escravo não é tão fácil assim' ${ }^{130}$.

Além da Campanha Nacional, foi desenvolvido também o programa “Escravo, nem Pensar!”, coordenado pela ONG Repórter Brasil em parceria com a Secretaria Especial de Direitos Humanos da Presidência da República e outras mais de 30 instituições. O programa foi lançado em setembro de 2008, no bojo do $2^{\circ}$ Plano Nacional para Erradicação do Trabalho Escravo e seu objetivo é promover a capacitação de professores e lideranças populares, professores e educadores para combater o trabalho escravo em suas comunidades e transmitir informações sobre os direitos trabalhistas. O programa também visa a articulação entre entidades locais que antes agiam de forma pulverizada. A fim de acompanhar o projeto, a

\footnotetext{
${ }^{129}$ Ibid., p. 169-170.

${ }^{130}$ OIT. Combatendo o trabalho escravo contemporâneo: o exemplo do Brasil, 2010, p. 170.
} 
Repórter Brasil visita cada município após a formação dos "agentes da cidadania" e se atualiza sobre o que está sendo feito ${ }^{131}$.

Para finalizar, não poderíamos deixar de mencionar o "ProgramaPiloto de Reinserção do Trabalhador Resgatado: A Iniciativa do Instituto Carvão Cidadão (ICC)". Criado em 2004, o programa tem como objetivo a reinserção de trabalhadores resgatados de situações análogas à de escravidão em empregos formais, pelas empresas do setor siderúrgico associadas ao ICC, com a garantia de que os direitos trabalhistas serão assegurados. O objetivo dessa iniciativa é evitar a reincidência na situação de exploração ${ }^{132}$.

\subsection{Ameaças ao Enfrentamento ao Trabalho Escravo Contemporâneo}

A despeito das medidas alcançadas pelo Brasil para enfrentar o trabalho escravo contemporâneo e o reconhecimento internacional de alguns avanços conquistados ${ }^{133}$ - que não foram muitos e não foram capazes de combater as causas estruturais do trabalho escravo - algumas questões merecem ser analisadas por representarem ameaças ao que até aqui foi

${ }^{131}$ Disponível em: <http://escravonempensar.org.br/sobre-o-projeto/quem-somos/>. Acesso em: 08 nov. 2016.

Informações também disponíveis em: OIT. Combatendo o trabalho escravo contemporâneo: o exemplo do Brasil, 2010, p. 174.

${ }^{132}$ SHAHINIAN, 2010, p. 11.

OIT. Combatendo o trabalho escravo contemporâneo: o exemplo do Brasil, 2010, p. 177.

A OIT-Brasil informa que, para realizar esse programa de reinserção "o MTE fornece ao ICC a lista dos trabalhadores libertados nas ações do GEFM que recebm o Seguro Desemprego. A partir dessa lista, o ICC inicia o trabalho de localização dos trabalhadores, oferecendo aos mesmos trabalhos formais nas referidas empresas. Após a localização e a aceitação da proposta de emprego, o ICC providencia a documentação necessária, visto que grande parte dos trabalhadores não possui sequer Certidão de Nascimento. A seguir, o trabalhador é encaminhado à Siderúrgica para sua admissão".

${ }^{133}$ A ONU-Brasil enaltece e reconhece, em relatório de abril de 2016, que o país avançou no âmbito das políticas que promovem a erradicação do trabalho escravo. Todavia, ressalta que há muito a ser feito. NAÇÕES UNIDAS NO BRASIL (ONUBR). Trabalho Escravo. Brasília, abril de 2016. p. 5-8.

A então relatora especial para formas contemporâneas de escravidão, Gulnara Shahinian, em sua visita ao Brasil em 2010, também parabenizou o Brasil por todas as medidas tomadas e pelo grande avanço no combate ao trabalho escravo desde o reconhecimento de sua existência em 1995 e da celebração do Acordo de Solução Amistosa de 2003 perante a CIDH. Todavia, também apresenta lacunas nos programas e na legislação nacionais e faz recomendações.

SHAHINIAN, 2010. 
conseguido no que tange à erradicação de todas as formas contemporâneas de escravidão. Dentre essas questões, trataremos, em particular, do Projeto de Lei $N^{\circ} 432 / 2013$ do Senado, que visa a restringir o conceito de "trabalho escravo" (tópico 3.2.1), e da suspensão da Lista Suja (tópico 3.2.2). Para concluir esse capítulo, traçaremos um breve comentário acerca de outras ameaças (tópico 3.2.3).

\subsubsection{Projeto de Lei № $432 / 2013$}

A ONU Brasil, em seu position paper de abril de 2016, enalteceu as “boas práticas construídas pelo Brasil nos últimos 20 anos", concedendo uma especial atenção às reformas feitas na legislação nacional. A Organização destacou a alteração feita em 2003 ao art. 149 do Código Penal, afirmando que foi introduzido "um conceito moderno de trabalho escravo". Afirmou, ainda, que a OIT considerou o conceito adotado pelo Brasil como uma referência legislativa para o tema ${ }^{134}$.

A ONU utilizou-se de uma linguagem bastante diplomática de modo a incentivar o Brasil a continuar perseguindo uma significativa mudança na sua realidade. Contudo, não deixou de reconhecer que ainda existe uma grande discussão sobre a abrangência do conceito de trabalho escravo previsto no país. Essa discussão é revelada pelo constante esforço presente em setores do Congresso Nacional, geralmente representados pela "bancada ruralista" para revisar a legislação vigente, considerada exemplar pela ONU. Nesse sentido, tramita no Congresso Nacional o Projeto de Lei $\mathrm{n}^{\circ}$ 432/2013 ${ }^{135}$ do Senado, sob a justificativa de regulamentar a Emenda Constitucional $\mathrm{n}^{\circ} 81 / 2014^{136}$ (abordada no tópico 3.1 .1 do presente trabalho).

\footnotetext{
${ }^{134}$ NAÇÕES UNIDAS NO BRASIL (ONUBR). Trabalho Escravo. Brasília, abril de 2016. p. 5. 135 Para mais informações sobre o PL 432/2013, ver: Disponível em: <http://www25.senado.leg.br/web/atividade/materias/-/materia/114895>. Acesso em: 09 nov. 2016.

${ }^{136}$ Como já mencionado no tópico 3.1.1, a EC n. 81 faz um acréscimo ao art. 243 da CF, que já contempla o confisco de terrar onde forem encontradas lavouras de psicotrópicos. Com a
} 
Alguns parlamentares contrários à "PEC do Trabalho Escravo" (que se converteria na EC n. 81 em junho de 2014) condicionaram sua deliberação em plenário a uma regulamentação com discussão conceitual. Do contrário, a PEC não teria conseguido apoio suficiente no Congresso para prosseguir tramitando e continuaria estagnada, como ficou por mais de uma década até sua aprovação. É importante mencionar que, desde sua proposição, a PEC do Trabalho Escravo entrou e saiu de pauta inúmeras vezes. Ressalte-se, ainda, que a mesma foi aprovada em primeiro turno na Câmara em agosto de 2004, após muita pressão popular gerada pelo assassinato de três auditores fiscais e de um motorista do MTE durante fiscalização rural em Minas Gerais, em janeiro de 2004, fato que ficou conhecido como "Chacina de Unaí”, sobre a qual já discutimos em capítulo anterior. Devido à grande mobilização social, o que levaria em algum momento à aprovação da proposta, a bancada ruralista mudou de tática e adotou como estratégia a tentativa de alterar o conceito de trabalho escravo. Assim, conseguiriam fazer com que a aprovação da PEC se tornasse uma oportunidade para descaracterizar o entendimento adotado atualmente de escravidão e, como consequência, a própria EC se tornaria inócua após ser regulamentada.

Dessa forma, foi acrescentado ao texto da PEC o termo "na forma da lei”. À época, o presidente do Senado, Renan Calheiros, afirmou que o termo foi acrescentado para reforçar a necessidade de regulamentar a Emenda. Nesse sentido, a proposta de regulamentação passou a ser discutida, a qual apontaria, além de um novo conceito de trabalho escravo, como se daria o perdimento das terras, imóveis e benfeitoras em caso de flagrante de mão de obra análoga à escrava. Nesse sentido, com a aprovação da PEC, os esforços passaram a ser investidos no PL 432/2013, cujo objetivo passou a ser, no fundo, o esvaziamento da Emenda recém aprovada.

aprovação da EC, passa-se a confiscar também as terras em que for encontrada exploração de mãode-obra análoga a de escravo. 
O Projeto de Lei adota um conceito parcial de trabalho escravo, mais restrito do que aquele previsto no art. 149 do Código Penal. É importante esclarecer que se trata de uma definição não encampada pelo governo federal, mas alinhada com os interesses da "bancada ruralista" do Congresso Nacional, que exclui jornada exaustiva e condições degradantes da conceituação.

A lei vigente insere como elementos que determinam o trabalho escravo: condições degradantes de trabalho, jornada exaustiva, trabalho forçado e servidão por dívida. A legislação brasileira considera não apenas a liberdade, mas também a dignidade como valores que precisam ser protegidos, motivo pelo qual recebeu os elogios citados no início desse tópico.

Por essa análise, resta evidente que o PL 432/2013 ameaça retroceder no que tange ao conceito atualmente adotado no país, posto que visa a restringi-lo e a torná-lo mais brando. Nesse sentido, Xavier Plassat, coordenador da campanha de combate ao trabalho escravo da CPT, afirmou à ONG Repórter Brasil que “a confusão sobre o conceito é uma falácia da bancada ruralista para inutilizar não só a PEC aprovada, mudando assim a definição do crime, mas o próprio combate à escravidão" ${ }^{137}$.

À época em que terminava a votação da PEC do Trabalho Escravo, Leonardo Sakamoto da ONG Repórter Brasil entrevistou parlamentares favoráveis à PEC, bem como representantes do governo, que afirmaram não haver necessidade de rever o conceito de trabalho escravo, pois o mesmo já é claro no art. 149 do CP. Os mesmos defenderam a aprovação de legislação infraconstitucional apenas para regulamentar a expropriação e não para alterar o conceito. Um deputado chegou a declarar para Leonardo Sakamoto que "a impressão é que ruralistas querem que seja punido

137 Disponível em: <http://blogdosakamoto.blogosfera.uol.com.br/2014/05/27/confisco-deimoveis-flagrados-com-escravos-e-aprovpelo-congresso/>. Acesso em: 09 nov. 2016. 
apenas quem for encontrado com pelourinho, chicote e grilhões, além do recibo de compra do escravo" ${ }^{138}$.

Acerca do acima exposto, a ONU Brasil declarou em seu position paper de abril de 2016:

Há, ainda, uma grande discussão sobre a abrangência do conceito de trabalho escravo no Brasil, revelada sob um contínuo esforço de revisar a legislação atualmente vigente sobre o tema, considerada já tão vanguardista pela ONU. O Projeto de Lei 432/2013, por exemplo, tramita no Congresso a pretexto de regulamentar a Emenda Constitucional $\mathrm{n}^{\circ} 81$ (que trata da expropriação de propriedades flagradas com trabalho escravo). No entanto, o que se verifica, na prática, é uma tentativa de reduzir as hipóteses de sua abrangência para situações em que se identifica apenas o cerceamento à liberdade do trabalhador. Situações em que trabalhadores são submetidos a condições degradantes ou jornadas exaustivas, maculando frontalmente sua dignidade, ficariam impunes caso essa alteração legislativa seja aprovada ${ }^{139}$. (grifos no original)

Portanto, resta esclarecida a razão para preocupação quanto aos significativos retrocessos consequentes de eventual aprovação do tão discutido PL 432/2013.

\subsubsection{Suspensão da Lista Suja}

Outro fato recente, que demonstra um enorme retrocesso em relação ao enfrentamento ao trabalho escravo contemporâneo, foi a suspensão do Cadastro de Empregadores flagrados explorando mão de obra escrava, cadastro conhecido como "Lista Suja" (sobre o qual tratamos no tópico 3.1.2.iv) $)^{140}$, que era considerado um dos mecanismos mais eficazes ao enfrentamento do trabalho escravo contemporâneo.

Em 23 de dezembro de 2014, no meio do plantão do recesso de final de ano, em tempo recorde, o ministro Ricardo Lewandowski deferiu uma liminar em resposta à Ação Direta de Inconstitucionalidade (ADIn) 5209141,

\footnotetext{
138 Ibid., Acesso em: 10 nov. 2016.

${ }^{139}$ NAÇÕES UNIDAS NO BRASIL (ONUBR). Trabalho Escravo. Brasília, abril de 2016. p. 6. ${ }^{140}$ NAÇÕES UNIDAS NO BRASIL (ONUBR). Trabalho Escravo. Brasília, abril de 2016. p. 6. ${ }^{141}$ A ADI 5209 pode ser acompanhada no site do Supremo Tribunal Federal. BRASIL. Supremo Tribunal Federal. Disponível em: <http://www.stf.jus.br/portal/processo/verProcessoAndamento.asp>. Acesso em: 11 nov. 2016.
} 
protocolada no STF no dia 22 de dezembro de 2014 e proposta pela Associação Brasileira de Incorporadoras Imobiliárias (ABRAINC) - à qual estão associadas grandes construtoras. A liminar suspende, até o julgamento definitivo da ADIN a Portaria Interministerial MTE/SDH n ${ }^{\circ}$, de 12 de maio de 2011, e a Portaria MTE $n^{\circ}$ 540, de 19 de outubro de 2004, que tratam da criação e manutenção da Lista Suja.

A ABRAINC questionou a constitucionalidade da Lista Suja por meio dos seguintes argumentos: (i) a Lista deveria ser prevista em lei específica e não por uma portaria interministerial, fato que usurpa a competência do Poder Legislativo; e (ii) a inclusão do nome do suposto infrator ocorre após decisão final em processo administrativo, que é iniciado após realização de ação fiscal que identifique submissão de trabalhadores em situação análoga a de escravo, sendo essa identificação considerada unilateral pois não assegura o contraditório e a ampla defesa ao sujeito fiscalizado ${ }^{142}$.

Ambos os argumentos foram acatados pelo então Presidente do STF, Ministro Lewandowski, em sua decisão liminar. Devido à suspensão, uma atualização da relação de empregadores que seria divulgada no dia 30 de dezembro de 2014 foi bloqueada e o governo federal foi proibido de divulgar a Lista Suja.

Diante disso, a ONG Repórter Brasil e o Instituto Nacional pela Erradicação do Trabalho Escravo (InPacto), solicitaram, com fundamento nos artigos 10, 11 e 12 da Lei de Acesso À Informação (Lei $\mathrm{N}^{\circ}$ 12.527/2012, também chamada de LAI) e no artigo $5^{\circ}$ da Constituição Federal, que o Ministério do Trabalho (responsável desde 2003 pela Lista) fornecesse os dados dos empregadores autuados pela exploração de mão de

\footnotetext{
${ }^{142}$ BRASIL. Supremo Tribunal Federal. Medida Cautelar na Ação Direta de Inconstitucionalidade n. 5209. Relator: Ministra Cármen Lúcia. Brasília, 23 de dezembro de 2014. DJE nº 22, divulgação em 2.2.2015.
} 
obra escrava que tiveram decisão administrativa final nos dois anos anteriores $^{143}$.

A listagem fornecida pelo Ministério do Trabalho foi denominada pelos seus solicitantes como "Lista da Transparência". O objetivo das organizações ao veicular essa nova Lista é garantir o direito do setor empresarial e da sociedade à transparência sobre o tema, por meio do fornecimento de informações sobre os flagrantes realizados pelo governo de exploração de trabalho escravo. A Repórter Brasil esclarece que a transparência é fundamental para o funcionamento do mercado. Se uma determinada empresa não informar seus passivos ambientais, sociais e trabalhistas, estará sonegando relevantes informações necessárias a um investidor, financiador ou parceiro comercial ao realizar negócios ${ }^{144}$.

É importante ressaltar que as informações constantes da "Lista de Transparência" são oficiais, visto que são fornecidas pelo MTE ${ }^{145}$, através de solicitação formal, obedecendo aos trâmites legais previstos na LAI. Adicione-se a isso a informação de que essa solicitação pode ser repetida por qualquer cidadão, organização ou empresa e que essa nova Lista tem sido o principal instrumento para as empresas associadas do InPacto controlarem e monitorarem sua cadeia produtiva no que tange ao trabalho escravo.

A "Lista da Transparência" é, na verdade, igual a Lista Suja. Contudo, não tem a mesma força pois a Lista Suja era publicada pelo próprio Ministério do Trabalho, independente de solicitação de terceiros. Já a Lista da Transparência, apesar de conter o mesmo conteúdo da Lista Suja, é obtida por terceiros após requererem oficial e publicamente ao MTE, com

\footnotetext{
143 Disponível em: <http://blogdosakamoto.blogosfera.uol.com.br/2016/05/11/no-ultimo-diagoverno-lanca-portaria-que-recria-lista-suja-da-escravidao/>. Acesso em: 11 nov. 2016.

Repórter Brasil. Disponível em: <http://reporterbrasil.org.br/2016/06/lista-de-transparencia-traz349-nomes-flagrados-por-trabalho-escravo/>. Acesso em: 11 nov. 2016.

144 Disponível em: <http://reporterbrasil.org.br/2016/06/lista-de-transparencia-traz-349-nomesflagrados-por-trabalho-escravo/>. Acesso em: 11 nov. 2016.

${ }^{145}$ O governo federal envia o documento já com a logomarca do Ministério do Trabalho e Emprego e com uma explicação sobre o conteúdo da lista.
} 
base na LAI, as informações constantes em seus bancos de dados relativas a empregadores flagrados explorando mão-de-obra escrava. Ao receberem essas informações do MTE, as organizações da sociedade civil publicam em seus próprios sites a Lista, por eles chamada "Lista da Transparência". Note-se que, para que esses dados sejam divulgados por terceiros, há um longo processo burocrático, antes inexistente.

A Lista de Transparência já está em sua quarta edição e traz os dados dos empregadores autuados que tiveram decisão administrativa final entre abril de 2014 e abril de 2016. Os dados foram compilados pelo MTE e o extrato com o resultado foi recebido no dia 6 de junho de 2016 e divulgado no mesmo dia pela Repórter Brasil e pelo InPacto. A última lista continha o nome de 350 empregadores, mas apenas foram publicados 349 nomes devido a uma liminar concedida pelo Tribunal de Justiça da Bahia em favor de uma empresa local ${ }^{146}$.

No dia 11 de maio de 2016, ao final do governo de Dilma Rousseff, foi assinada pelo governo federal uma nova portaria interministerial, a Portaria n. 4/2016 ${ }^{147}$, recriando o cadastro de empregadores flagrados explorando mão de obra escrava. Essa nova portaria pretende esclarecer um dos principais argumentos utilizados por Lewandowski para, à época, conceder a medida cautelar requerida pela ABRAINC: o de que a portaria anterior violava a ampla defesa e o contraditório dos empregadores cadastrados $^{148}$.

Por ocasião dessa nova portaria, a Ministra Relatora da ADIn 5209, Ministra Cármen Lúcia, proferiu uma decisão em 24 de maio de 2016, julgando prejudicada a ADIn e cassando a medida cautelar deferida em

\footnotetext{
${ }^{146}$ A "Lista de Transparência" pode ser acessada nos sites da Repórter Brasil e do InPacto.

${ }^{147}$ A Portaria Interministerial n.4/2016 foi publicada no Diário Oficial da União em 13 de maio de 2016. Disponível em:

<http://pesquisa.in.gov.br/imprensa/jsp/visualiza/index.jsp?data=13/05/2016\&jornal=1\&pagina=1 78\&totalArquivos=304> . Acesso em: 13 nov. 2016.

148 SAKAMOTO, Leonardo. Disponível em: <http://reporterbrasil.org.br/2016/05/no-ultimo-diagoverno-lanca-portaria-que-recria-lista-suja-da-escravidao-2/>. Acesso em: 13 nov. 2016.
} 
Dezembro de 2014 pelo então Presidente do STF, Ministro Lewandowski, sob o fundamento de perda superveniente do objeto da ação ${ }^{149}$.

A Portaria Interministerial n.4/2016 aprimorou os critérios de entrada e saída de empregadores na Lista Suja, sendo agora necessária a aplicação de um auto de infração específico para condição análoga a de escravo (com a Portaria antiga, a caracterização podia acontecer por meio de um conjunto de autos de infração). Ela assegura em seu artigo $2^{\circ}$, claramente, o exercício do contraditório e da ampla defesa no que tange à conclusão da Inspeção do Trabalho de constatação de trabalho em condições análogas à de escravo. Destaque-se que a inclusão do empregador na Lista apenas poderá ocorrer após prolação de decisão administrativa irrecorrível de procedência do auto de infração lavrado na ação fiscal. Por se tratar de processo administrativo, não é necessária a prévia condenação do empregador na esfera judicial. O artigo $3^{\circ}$ da Portaria estabelece que o nome do empregador permanecerá divulgado na Lista durante dois anos, ao longo dos quais a Inspeção do Trabalho realizará monitoramento a fim de verificar a regularidade das condições de trabalho. A nova Portaria prevê, ainda, a possibilidade de o empregador flagrado assinar um Termo de Ajustamento de Conduta (TAC) ou acordo judicial. O empregador que celebrar o TAC ou o acordo judicial não integrará a relação disciplinada no artigo $2^{\circ}$ da Portaria, mas uma segunda relação, sendo que ambas deverão integrar o mesmo documento e meio de divulgação ${ }^{150}$.

Ainda não há, porém, previsão para publicação de uma nova relação dos empregadores autuados por exploração de trabalho análogo ao de

\footnotetext{
149 BRASIL. Supremo Tribunal Federal. Ação Direta de Inconstitucionalidade. ADIn n. 5209. Associação Brasileira de Incorporadoras Imobiliárias - Abrainc -, Ministro de Estado do Trabalho e Emprego e Ministra de Estado Chefe da Secretaria de Direitos Humanos da Presidência da República. Relator: Ministra Cármen Lúcia. Brasília, 24 de maio de 2016. Publicado no DJE nº 106, publicado em 23.05.2016. Disponível em:

<http://www.stf.jus.br/portal/processo/verProcessoAndamento.asp>. Acesso em: 13 nov. 2016.

150 Disponível em: <http://www.conjur.com.br/2016-jun-05/gustavo-garcia-norma-escravidaomelhora-condicoes-trabalho>. Acesso em: 13 nov. 2016.

SAKAMOTO, Leonardo. Disponível em: <http://reporterbrasil.org.br/2016/05/no-ultimo-diagoverno-lanca-portaria-que-recria-lista-suja-da-escravidao-2/>. Acesso em: 13 nov. 2016.
} 
escravo, o que deverá ser de responsabilidade do Ministério do Trabalho sob a gestão do atual Presidente da República, Michel Temer ${ }^{151}$.

Para finalizar, não é possível deixar de mencionar que existe um Projeto de Decreto Legislativo que visa a sustar a aplicação da Portaria Interministerial n. 4/2016, recém-aprovada. Trata-se do PDC 532/2016, que aguarda designação de relator na Comissão de Trabalho, de Administração e Serviço Público e cuja justificativa para sustar a nova Portaria é a:

\begin{abstract}
Necessidade urgente de elaboração de uma definição clara e objetiva do termo 'trabalho escravo', contida no art. 243 da Constituição Federal - CF, e das expressões correlatas 'condição análoga à de escravo', 'trabalhos forçados', 'jornada exaustiva' e 'condições degradantes de trabalho', contidas no caput do art. 149 do Código Penal ${ }^{152}$.
\end{abstract}

É possível perceber, portanto, o novo desafio para resgatar a publicação pelo MTE da Lista Suja, que se encontra suspensa desde 2014. Não obstante a ADIn 5209, que a suspendeu, ter sido declarada prejudicada pela nova Portaria Interministerial que recria a Lista Suja, a mesma ainda não foi publicada e dependerá de um novo cenário político no país, presidido por um novo governo. Ademais, paira a ameaça de uma nova suspensão, caso o Projeto de Decreto Legislativo 532/2016 seja aprovado. A Lista Suja se encontra, portanto, em um momento de grave vulnerabilidade.

Pelo exposto, resta evidente a enorme resistência na criação e manutenção de mecanismos de enfrentamento ao trabalho escravo, os quais estão em constante ameaça de retrocesso. Interessante notar como o próprio ordenamento jurídico acaba por legitimar, por sua suposta neutralidade, a manutenção de uma sociedade absorvida pelo escravismo, que luta para não reconhecer sua própria realidade.

\footnotetext{
${ }^{151}$ Ibid., Acesso em: 13 nov. 2016.

152 Para acompanhar mais detalhadamente o Projeto de Decreto Legislativo 532/2016, ver: Disponível em:

<http://www.camara.gov.br/proposicoesWeb/fichadetramitacao?idProposicao=2113066>. Acesso em: 13 nov. 2016.
} 


\subsubsection{Outras Ameaças}

Além da tentativa de restringir o conceito de trabalho escravo por meio do PL 432/2013 e da atual situação de vulnerabilidade da Lista Suja, outras ameaças ao enfrentamento ao trabalho escravo contemporâneo devem ser destacadas.

A primeira grande ameaça tem sido o enfraquecimento dos Grupos Móveis de Fiscalização e a progressiva redução do número de auditores fiscais do trabalho, devido à ausência de concursos públicos para essa carreira. Esses fatos geram grande preocupação, pois a inspeção do trabalho é a responsável pelo resgate de trabalhadores dessa condição desumana de redução à condição análoga à escravidão ${ }^{153}$.

A segunda grande ameaça é a regulamentação da EC n. 81/2014. Conforme já mencionado, está em discussão a suposta explicitação - leiase, restrição - do conceito de trabalho escravo por meio do PL 432/12. Como também já mencionado, foi acrescentado ao texto da norma a expressão "na forma da lei", o que faz com que seja necessária regulamentação do termo "trabalho escravo" para que a Emenda Constitucional seja aplicável. Contudo, é necessário, também, regulamentar e disciplinar o processo de expropriação de terras, é preciso esclarecer quando e como a terra onde for flagrado trabalho escravo e tudo o que nela houver será confiscado e o que será feito com esses bens. O PL 432/12 também visa a tratar dessa questão e prevê que a expropriação só seja autorizada depois que o proprietário da área em que era explorada mão-deobra escrava tenha esgotado todos os recursos legais contra a sentença penal condenatória.

É essencial manter em mente que uma das maiores dificuldade no que tange esse tema é a investigação, julgamento e punição dos empregadores flagrados. Ademais, não se pode olvidar da grande disputa no

\footnotetext{
${ }^{153}$ NAÇÕES UNIDAS NO BRASIL (ONUBR). Trabalho Escravo. Brasília, abril de 2016. p. 6.
} 
Congresso Nacional travada pela bancada ruralista que visa a tornar a Emenda Constitucional n. 81 inócua.

Diante de todo o exposto, é possível observar que as medidas adotadas pelo Brasil desde 2003, por ocasião da Solução Amistosa, marcaram o início de uma possível mudança no que tange o enfrentamento ao trabalho escravo. Contudo, essas medidas ainda não foram suficientes para romper com as amarras arcaicas e combater as causas estruturais do trabalho escravo em nosso país. As ameaças que podem ser observadas ao incipiente processo de evolução dos direitos humanos no que tange ao trabalho escravo, dentre as quais pudemos elencar algumas, são um reflexo político, social e econômico que perpassa a história desse país. Dessa forma, ainda há muito a ser feito.

Reconhecendo esse grande desafio - que não é particular apenas do Brasil, mas de grande parte dos Estados membros da OEA - a CIDH submeteu o Caso Fazenda Brasil Verde à Corte IDH, a qual terá a oportunidade de estabelecer um novo marco a partir de seu julgamento. $\mathrm{O}$ capítulo a seguir será dedicado a analisar esse caso e as expectativas quanto à sua iminente sentença. 


\section{CAPÍTULO 4 - O CASO FAZENDA BRASIL VERDE VS. BRASIL}

Além do Caso José Pereira, outro caso relacionado à exploração de trabalho escravo no Brasil estava sob análise da Comissão Interamericana de Direitos Humanos, o Caso Fazenda Brasil Verde, cujo pano de fundo não se distancia muito do primeiro. Os fatos ocorreram no mesmo estado: o Pará; na mesma época: entre os anos 1988 e 2000; no mesmo contexto: aliciamento de pessoas vulneráveis para trabalharem em fazendas em condições degradantes, com restrição à liberdade e sob forte ameaça; com respostas semelhantes: inércia estatal; e com os mesmos peticionários: CEJIL e CPT.

Apesar dessas semelhanças, o desfecho internacional foi distinto. Enquanto no Caso José Pereira o Estado realizou um Acordo de Solução Amistosa, no Caso Brasil Verde as tratativas na Comissão Interamericana se estenderam por muito mais tempo e o Estado mostrou menos interesse em cumprir com as recomendações da mesma. Por fim, o Caso foi submetido à Corte Interamericana.

Segundo as informações disponíveis em entrevista concedida pelo Frei Xavier Plassat, da Comissão Pastoral da Terra, ao Instituto Humanitas Unisinos (IHU) ${ }^{154}$, as negociações com o Estado brasileiro foram frustradas. A ideia dos peticionários era solicitar a reparação imediata de mais de 300 vítimas, identificar por que haviam ocorrido tantos erros e, principalmente, criar mecanismos inovadores e efetivos de prevenção e não repetição, além de ferramentas mais eficazes de coleta de provas em caso de flagrante de trabalho escravo durante as fiscalizações, de modo a facilitar eventuais ações penais e suas conclusões em um tempo razoável.

\footnotetext{
154 Disponível em: <http://www.ihu.unisinos.br/entrevistas/552215-trabalho-escravo-no-brasil-osriscos-de-passar-de-vitrine-a-vidraca-entrevista-especial-com-xavier-plassat>. Acesso em: 15 nov. 2016.
} 
Xavier Plassat afirmou que as partes do processo quase chegaram a um acordo, todavia, durante cerca de um ano o Estado protelou a concretização de qualquer medida, sem cumprir nada de específico. A própria CIDH informou que enviou seu relatório de admissibilidade e mérito ao Estado brasileiro em 4 de janeiro de 2012 e lhe concedeu um prazo de dois meses para informar sobre o cumprimento das recomendações. Contudo, segundo a CIDH, foram concedidas 10 prorrogações ao Estado, sem que o mesmo avançasse concretamente em nenhuma das recomendações ${ }^{155}$.

Diante desse cenário, bem como das demonstrações feitas pelos peticionários de graves ameaças à evolução do enfrentamento ao trabalho escravo, sobre as quais já tratamos no capítulo anterior, a Comissão decidiu submeter o caso à Corte Interamericana, sendo assim a primeira vez que a Corte julgará um caso cuja temática central é a exploração de trabalho escravo. Trata-se, pois, de uma grande oportunidade de estabelecer parâmetros importantes para os países membros da Organização dos Estados Americanos de identificação, prevenção, combate e sanção ao trabalho escravo ${ }^{156}$.

\subsection{Os Fatos do Caso e as Considerações da CIDH}

O Caso Fazenda Brasil Verde versa sobre a ineficácia do Estado brasileiro na tomada de providências necessárias para evitar a exploração de trabalhadores na referida fazenda entre 1988 e 2000, apesar de o mesmo ter recebido diversos alertas. Ademais, o caso analisa a falta de esforços do

\footnotetext{
155 Informações obtidas por meio do documento em que a Comissão submete o Caso Fazenda Brasil Verde vs. Brasil à jurisdição da Corte, datado de 4 de março de 2015. Disponível em: <https://www.oas.org/es/cidh/decisiones/corte/2015/12066NdeResPT.pdf〉. Acesso em: 15 nov. 2016.

${ }^{156}$ PLASSAT, Xavier. Caso de trabalho escravo faz OEA pôr Brasil no banco dos réus: Governo brasileiro foi julgado por omissão no combate aos casos da fazenda Brasil Verde. 01 de março de 2016. Repórter Brasil. Disponível em: <http://reporterbrasil.org.br/2016/03/caso-de-trabalhoescravo-faz-oea-por-brasil-no-banco-dos-reus/>. Acesso em: 15 nov. 2016.
} 
Estado para punir os responsáveis pela exploração dos trabalhadores ${ }^{157}$. Somado a isso está o desaparecimento de dois jovens após os mesmos tentarem fugir da Fazenda Brasil Verde, os quais até a presente data não foram encontrados. O Estado tampouco empreendeu esforços suficientes no sentido de investigar o ocorrido.

Durante esses doze anos, os fiscais do governo estiveram na propriedade em seis diferentes ocasiões para averiguar as condições em que se encontravam os trabalhadores: fevereiro de 1989, março de 1993, novembro de 1996, abril e novembro de 1997 e março de 2000 ${ }^{158}$. Ao longo dessas fiscalizações, foram resgatados cerca de 340 trabalhadores em condições degradantes ${ }^{159}$. Nenhum deles foi devidamente indenizado e nenhum dos responsáveis foi punido.

Buscando uma melhor compreensão do caso em apreço, serão analisados com maior profundidade os fatos e as medidas adotadas pelo Estado (tópico 4.1.1). Em seguida, serão elencadas as considerações da Comissão Interamericana de Direitos Humanos sobre o caso (tópico 4.1.2).

É importante esclarecer que, no presente capítulo, apenas trataremos das medidas que o Brasil adotou especificamente em relação ao Caso Fazenda Brasil Verde. As medidas de prevenção abordadas no tópico 2.4.2 do presente trabalho foram também consideradas pela CIDH em seu Relatório acerca do Caso em comento. Contudo, por já termos explorado

\footnotetext{
${ }^{157}$ Relatório n 169/11, Caso 12.066 Admissibilidade e Mérito: Fazenda Brasil Verde vs. Brasil. OEA/Ser/L/V/II.143. Doc. 53. 3 de novembro de 2011; PLASSAT, Xavier. Caso de trabalho escravo faz OEA pôr Brasil no banco dos réus: Governo brasileiro foi julgado por omissão no combate aos casos da fazenda Brasil Verde. 01 de março de 2016. Repórter Brasil. Disponível em: $<$ http://reporterbrasil.org.br/2016/03/caso-de-trabalho-escravo-faz-oea-por-brasil-no-banco-dosreus/>. Acesso em: 15 nov. 2016.

158 Disponível em: <https://www.oas.org/es/cidh/decisiones/corte/2015/12066NdeResPT.pdf〉. Acesso em: 15 nov. 2016.

159 Informação disponível na reportagem: Brasil será julgado por trabalho escravo: Corte Interamericana de Direitos Humanos analisa a responsabilidade do país. 18 de fevereiro de 2016. O GLOBO. Disponível em: <http://oglobo.globo.com/economia/brasil-sera-julgado-por-trabalhoescravo-18696839>. Acesso em: 15 nov. 2016.

Informação disponível, também, no seguinte artigo publicado pela Repórter Brasil: PLASSAT, Xavier. Caso de trabalho escravo faz OEA pôr Brasil no banco dos réus: Governo brasileiro foi julgado por omissão no combate aos casos da fazenda Brasil Verde. 01 de março de 2016. Repórter Brasil. Disponível em: <http://reporterbrasil.org.br/2016/03/caso-de-trabalho-escravofaz-oea-por-brasil-no-banco-dos-reus/>. Acesso em: 15 nov. 2016.
} 
essas medidas em capítulo anterior, nos limitaremos a fazer uma análise descritiva das fiscalizações realizadas na Fazenda Brasil Verde, as medidas processuais específicas e a reparação das as vítimas do caso.

Para tanto, serão utilizadas as informações contidas em dois documentos: o Relatório de Admissibilidade e Mérito da CIDH (Relatório $\left.\mathrm{n}^{\circ} 169 / 11\right)^{160}$ e o documento oficial em que a CIDH submete o Caso Fazenda Brasil Verde à Corte IDH $^{161}$.

Ressaltamos que os fatos que serão analisados a seguir são bastante extensos. Optamos, todavia, por relatá-los a despeito de sua complexidade, pois evidenciam de forma muito contundente os padrões de exploração de trabalho escravo no Brasil, principalmente na região norte e, especialmente, a aquiescência do Estado para com tal violação de direitos humanos. Essa análise demonstra a legitimação, por parte de nosso próprio ordenamento jurídico, de uma sociedade que nunca aboliu a escravidão e permanece sem empreender esforços suficientes para combater as causas estruturais dessa prática desumana, perante a qual esperamos que a Corte IDH se posicione.

\subsubsection{Os fatos provados do caso e as medidas adotadas pelo Estado}

Entre o final de 1988 e início de 1989, a Polícia Federal brasileira recebeu denúncias de trabalho escravo em várias fazendas no município de Sapucaia, no sul do estado do Pará, dentre elas, a Fazenda Brasil Verde. O proprietário dessa fazenda formava parte do Grupo Irmãos Quagliato, os quais possuíam inúmeras fazendas nessa região e cerca de 130.000 cabeças de $\operatorname{gado}^{162}$.

Em 21 de dezembro de 1988, Adailton Martins dos Reis, trabalhador que havia fugido da Fazenda Brasil Verde, deu seu testemunho,

\footnotetext{
${ }^{160}$ Relatório n 169/11, Caso 12.066 Admissibilidade e Mérito: Fazenda Brasil Verde vs. Brasil. OEA/Ser/L/V/II.143. Doc. 53. 3 de novembro de 2011.

161 Disponível em: <https://www.oas.org/es/cidh/decisiones/corte/2015/12066NdeResPT.pdf>. Acesso em: 15 nov. 2016.

162 Relatório n¹69/11, Caso 12.066. Parágrafos 71 e 72.
} 
relatando as condições degradantes e desumanas às quais foi submetido durante o tempo que ali trabalhou. Narrou um contexto de maus-tratos, de falta de infra-estrutura do "barraco" em que viviam, do preço super inflacionado cobrado pelos produtos que apenas podiam ser comprados na fazenda, bem como a situação de fome, da promessa de "tiro" em caso de tentativa de fuga, dentre outras condições degradantes ${ }^{163}$.

Nessa mesma data, a Comissão Pastoral da Terra (CPT), junto ao pai e irmão, respectivamente, de Iron Canuto da Silva de 17 anos e Luis Ferreira da Cruz de 16 anos, denunciaram perante a Polícia Federal a prática de trabalho escravo na Fazenda Brasil Verde, assim como o desaparecimento desses dois adolescentes. Segundo a denúncia, em agosto de 1988 os dois rapazes foram levados junto com outras quarenta pessoas de Arapoema, Tocantins, por um "gato" para trabalhar por 60 dias na referida Fazenda. A denúncia indicava, ainda, que, ao tentar abandonar a fazenda, os adolescentes foram devolvidos à força "pelas orelhas", ameaçados e, logo depois, desapareceram ${ }^{164}$.

Em 24 de fevereiro de 1989 a Polícia Federal elaborou um relatório sobre as visitas realizadas a várias fazendas, dentre elas a Fazenda Brasil Verde, no qual manifestou que os trabalhadores rurais, que vinham de regiões distantes, recebiam quantias irrisórias como pagamento, que era insuficiente para subsistência e que por vezes nem mesmo eram efetuados. Portanto, os trabalhadores viam-se obrigados a contrair dívidas impagáveis, sendo essa uma das razões pelas quais muitos acabavam fugindo. Ademais, foi constatado que o "gato" fugiu da fazenda quando ficou sabendo que haveria visita de fiscalização. Apesar das condições, após entrevistar 39 trabalhadores, o relatório da Polícia Federal concluiu que não se configurava prática de trabalho escravo, mas confirmou a existência de baixos salários e infrações às leis trabalhistas. Por fim, o relatório informou que os "gatos" alegaram que os rapazes Iron Canuto e Luis Ferreira haviam

\footnotetext{
${ }^{163}$ Relatório n ${ }^{\circ} 169 / 11$, Caso 12.066. Parágrafo 73.

164 Ibid., Parágrafo 74.
} 
fugido para outra fazenda por conta das dívidas contraídas na Fazenda Brasil Verde ${ }^{165}$.

\section{Entre 23 de junho e 3 de julho de 1993 foi realizada nova visita} de fiscalização acompanhada de quatro agentes policiais federais, ocasião em que foi constatada a presença de 92 trabalhadores sem carteira de trabalho - 49 dos quais sequer tinham contrato de trabalho - e que manifestaram seu desejo de "deixar a propriedade". A diligência determinou o regresso de vários trabalhadores, que tinham sido contratados irregularmente, ao seu local de origem. À época, o MTE considerou que não se configurava a prática de trabalho escravo ${ }^{166}$.

O Subprocurador Geral da República considerou, num relatório relacionado às fiscalizações, que a atuação da Polícia Federal, em 1989, "deixou a desejar" pois não tomou as declarações dos trabalhadores por escrito, nem elaborou uma lista com o nome e a qualificação dos mesmos, tampouco tomou declarações do gerente da fazenda, nem solicitou a apresentação dos contratos de trabalho. Além disso, a Polícia Federal tampouco procedeu à busca dos menores de idade desaparecidos, não procurou armas dentro da fazenda ou verificou os preços dos produtos do armazém. O subprocurador adicionou que a falta de pagamento dos salários, a fuga do "gato" enquanto era realizada a fiscalização, bem como a controvérsia sobre fuga ou abandono do serviço pelos trabalhadores, justificavam a instauração de inquérito policial sobre eventual prática de crime contra a organização do trabalho ou de redução a condição análoga à de escravo. Contudo, ressaltou que grande parte dos delitos já havia prescrito e que o relativo ao trabalho escravo, apesar de não ter prescrito ainda, era inviável de ser comprovado, considerando que já havia transcorrido mais de cinco anos desde a data dos fatos. Em relação à fiscalização de 1993, destacou que esta não determinou a existência de

\footnotetext{
165 Relatório n¹69/11, Caso 12.066. Parágrafo 76.

166 Ibid., Parágrafo 80.
} 
prática de trabalho escravo, mas sim de aliciamento ilegal ou de frustração de direitos laborais. No fim de 1996, a Procuradoria arquivou o caso ${ }^{167}$.

Em 29 de novembro de 1996 foi realizada nova fiscalização, dessa vez pelo recém-criado Grupo de Fiscalização Móvel $^{168}$, o qual constatou a existência de irregularidades relacionadas à falta de registro dos empregados e, em geral, a manutenção de condições contrárias às disposições laborais. No momento da fiscalização havia ao menos setenta e oito trabalhadores ${ }^{169}$.

Em 10 de março de 1997, outro trabalhador que conseguiu fugir da Fazenda Brasil Verde, José da Costa Oliveira, procurou o Departamento de Polícia Federal do Pará e prestou declarações. Afirmou que o "gato" Raimundo o contratou para trabalhar na fazenda, mas que, ao chegar lá, já devia dinheiro por todos os gastos de hospedagem e pelos instrumentos de trabalho fornecidos pelo "gato". Acrescentou que os trabalhadores eram ameaçados de morte se denunciassem o "gato" ou o fazendeiro, se tentassem fugir, e que era comum esconder os trabalhadores quando o Ministério do Trabalho realizava fiscalizações. Devido a essa denúncia, o Grupo Móvel realizou nova fiscalização na referida fazenda de 21 a 30 de abril de $1997^{170}$.

O relatório dessa nova fiscalização constatou que os trabalhadores se encontravam em péssimas condições e que eram obrigados a assinar notas promissórias e renúncias em branco, que eram proibidos de sair da fazenda enquanto tivessem dívidas e que eram ameaçados de morte. Comprovou, ainda, a prática de esconder os trabalhadores quando ocorriam as

\footnotetext{
${ }^{167}$ Relatório n 169/11, Caso 12.066. Parágrafos 71 e 72. Parágrafo 80.

${ }^{168}$ Importante lembrar que o Grupo de Fiscalização Móvel foi criado em 1995, conforme analisado no tópico 3.1.2. ii. desse trabalho. Note-se que, até 1995, era a Polícia Federal que realizava as visitas de fiscalização.

${ }^{169}$ Relatório n¹69/11, Caso 12.066. Parágrafos 71 e 72. Parágrafo 82.

${ }^{170}$ Ibid., Parágrafo 84.
} 
fiscalizações. No momento dessa fiscalização havia oitenta e um trabalhadores na fazenda ${ }^{171}$.

Em resposta a esse relatório do Ministério do Trabalho, em 30 de junho de 1997, o MPF apresentou denúncia contra Raimundo Alves da Rocha, o "gato"; contra Antonio Alves Vieira, gerente da fazenda; e contra João Luiz Quagliato Neto, proprietário da fazenda. Portanto, foi dado prosseguimento à persecução penal dos responsáveis pela redução dos trabalhadores a condições análogas à escravidão ${ }^{172}$.

Paralelamente a esse processo penal, em 1997, foi instaurado um processo administrativo na $8^{\text {a }}$ Procuradoria Regional do Trabalho. Em 14 de novembro de 1997 foi realizada mais uma fiscalização na Fazenda Brasil Verde, mas a DRT optou por não autuá-la, apenas dando orientações no sentido de que as falhas fossem corrigidas e as normas trabalhistas cumpridas $^{173}$.

Em outubro de 1998 o Ministério Público do Trabalho solicitou à DRT do Pará uma nova fiscalização na fazenda, a qual informou que não pôde realizá-la por falta de recursos financeiros ${ }^{174}$.

Em 13 de setembro de 1999 foi realizada a audiência preliminar no processo penal instaurado contra Quagliato após o mesmo ter sido diversas vezes intimado. Em 17 de setembro de 1999, a pedido do MP, o juiz federal autorizou a suspensão condicional do processo em relação a Quagliato por dois anos, visto que o crime pelo qual foi denunciado previa uma pena menor que um ano ${ }^{175}$. Em 18 de maio de 2002, foi extinta a ação penal contra o proprietário da fazenda ${ }^{176}$.

\footnotetext{
${ }^{171}$ Relatório n 169/11, Caso 12.066. Parágrafos 71 e 72. Parágrafo 85.

172 Ibid., Parágrafo 87.

173 Ibid., Parágrafos 99 e 100.

${ }^{174}$ Ibid., Parágrafos 101 e 102.

175 O Relatório $n^{\circ}$ 169/11, em seu parágrafo 87, informa que João Luiz Quagliato Neto foi denunciado pelo crime previsto no artigo 203 (crime de frustração de direito assegurado por lei trabalhista) c/c o artigo 71 (crime continuado) do Código Penal.

${ }^{176}$ Relatório n 169/11, Caso 12.066. Parágrafos 71 e 72. Parágrao 88.
} 
Entre junho de 1997 e junho de 1999 foram intimados o "gato" e o gerente da fazenda e, quando por fim compareceram em junho de 1999, foi realizada a audiência de qualificação e o interrogatório. Mas em 16 de março de 2001, o juiz federal encarregado do caso decidiu pela incompetência absoluta da Justiça Federal para julgar o processo. Sendo assim, os autos foram enviados para a justiça estadual de Xinguara, Pará ${ }^{177}$.

Em março de 2000, o adolescente Antonio Francisco da Silva e o jovem Gonzalo Luiz Furtado conseguiram fugir da Fazenda Brasil Verde, e procuraram o Ministério do Trabalho em Marabá a fim de denunciar os fatos ocorridos, mas a única resposta que obtiveram foi a de que deveriam se dirigir à Polícia Federal. Eles se dirigiram, então, à Polícia Federal, que não tomou por termo suas declarações, apenas conduziu os rapazes à Comissão Pastoral da Terra. Em depoimento à CPT, alegaram que haviam sido aliciados por um "gato" em fevereiro de 2000, o qual lhes prometeu que o salário seria combinado ao chegarem na fazenda. Mas que, ao chegarem lá, suas carteiras de trabalho foram apreendidas e que a identidade de Antonio Francisco da Silva, que era menor de idade, foi falsificada pelo "gato". Acrescentaram que, quando informaram ao "gato" suas decisões de deixar a fazenda, este e o gerente os ameaçaram de morte. Os jovens relataram que, além deles, outros 32 trabalhadores encontravamse nas mesmas condições ${ }^{178}$.

\section{Em 15 de março de 2000, a DRT do Pará realizou uma nova} fiscalização ${ }^{179}$ na fazenda, em que constatou, mais uma vez, péssimas condições laborais, aliciamento ilegal com promessa de pagamento, e a manifesta decisão unânime dos trabalhadores de escapar e regressar às suas cidades de origem. A DRT concluiu, finalmente, que existia "trabalho

\footnotetext{
${ }^{177}$ Relatório n ${ }^{\circ} 69 / 11$, Caso 12.066. Parágrafos 71 e 72. Parágrafos 89 e 90.

${ }_{178}$ Ibid., Parágrafos 105 a 108.

179 Tendo em vista que o brasil reconheceu a competência jurisdicional da Corte em 10 de dezembro de 1998, os fatos que podem ser analisados pela Corte são: os referentes às constatações da fiscalização de março de 2000; o desaparecimento dos dois jovens pois permaneceram desaparecidos até data posterior ao reconhecimento de competência; a ineficaz proteção e garantia judiciais pois os processos penais e administrativos que haviam sido instaurados não cumpriram com as funções essenciais à justiça.
} 
escravo" na Fazenda Brasil Verde ${ }^{180}$. No momento dessa fiscalização havia, ao menos, oitenta e duas pessoas trabalhando no local ${ }^{181}$.

Em maio de 2000, com base na visita realizada em março, o MPT apresentou uma ação civil pública contra João Luiz Quagliato Neto, proprietário da fazenda. O MPT alegou que a referida fazenda mantinha os trabalhadores "num sistema de cárcere privado", razão pela qual restava caracterizado o trabalho "em regime de escravidão", e acrescentou que a situação era agravada por se tratarem de trabalhadores rurais analfabetos e sem esclarecimento algum, os quais eram submetidos a condições de vida degradantes ${ }^{182}$.

Em 20 de julho de 2000 foi realizada uma audiência de conciliação entre o proprietário da fazenda e o Ministério Público do Trabalho, na qual demandado se comprometeu a não permitir o trabalho em regime de escravidão e a fornecer as condições adequadas de trabalho, moradia e higiene, sob pena de cobrança de multa por cada violação, em valor determinado nas cláusulas do acordo. Em 18 de agosto de 2000, o procedimento foi arquivado ${ }^{183}$.

\section{De 12 a 18 de maio de 2002, o MPT realizou mais uma} fiscalização na Fazenda Brasil Verde e concluiu que a mesma "vinha cumprindo seus compromissos" e que havia eliminado "a dependência econômica e física dos trabalhadores pelos 'gatos"', o que resultava na exploração de mão de obra escrava ${ }^{184}$.

Em 21 de novembro de 2003, dando continuidade ao processo penal, o MP estadual do Pará apresentou suas alegações finais, nas quais, surpreendentemente, solicitou que a denúncia contra o "gato" e o gerente

\footnotetext{
${ }^{180}$ Faz-se necessário tecer um comentário sobre a indefinição do conceito de trabalho escravo na época em que foram realizadas as fiscalizações. O Código Penal brasileiro só passou a ter a atual definição, elogiada pela ONU, a partir de 2003, após a celebração do Acordo de Solução Amistosa no Caso José Pereira.

${ }^{181}$ Relatório n¹69/11, Caso 12.066. Parágrafos 71 e 72. Parágrafo 109.

${ }^{182}$ Ibid., Parágrafo 111.

183 Ibid., Parágrafo 112.

184 Ibid., Parágrafo 115.
} 
fosse considerada improcedente e que eles fossem absolvidos por falta de indícios suficientes de autoria ${ }^{185}$.

Em novembro de 2004 a justiça estadual declarou-se incompetente para julgar o processo penal, o que suscitou um conflito de competência e os autos do processo foram remetidos ao Superior Tribunal de Justiça (STJ), que decidiu pela competência da Justiça Federal. Ou seja, o processo penal teve início na Justiça Federal em 1997, que se declarou incompetente, remetendo o caso à justiça estadual em 2001, que por sua vez também se declarou incompetente em 2004. Dessa forma, o STJ precisou solucionar esse conflito de competência, decidindo pela competência federal. Nesse sentido, em dezembro de 2007 os autos foram enviados à Justiça Federal de Marabá, Pará186. Portanto, percebe-se que durante dez anos permaneceu sendo discutida uma questão preliminar, que deveria ter sido decidida de imediato.

Em 10 de julho de 2008, o MPF apresentou suas alegações finais, solicitando a decretação da extinção da punibilidade do "gato" e do gerente, com a seguinte fundamentação:

[...] o relatório de fiscalização do Ministério do Trabalho narra as condições inóspitas vivenciadas pelos trabalhadores da Fazenda Brasil Verde, sem água potável para beber, dormindo em barracões cobertos de plástico e palha, chão batido e sem instalações sanitárias, desprovidos de quaisquer equipamentos de segurança individual, sem qualquer proteção contra intempéries. Ademais, verificou-se a prática de crimes de frustração, mediante fraude, de direitos assegurados pela legislação trabalhista.

[...] há prova suficiente de autoria da prática dos delitos de redução a condição análoga à de escravo (art. 149, caput), atentado contra a liberdade de trabalho (art. 197, I), e aliciamento de trabalhadores de um local para outro do território nacional (art. 207), mediante apreensão por dívidas,

[...] não obstante a comprovação de autoria e materialidade da trama delituosa, os crimes descritos nos artigos 197, I e 207 do CP, infelizmente, já foram alcançados pela prescrição, considerando que os fatos foram constatados no período de 21 a 30 de abril de 1997 e a pena máxima cominada aos respectivos

\footnotetext{
185 Relatório n ${ }^{169 / 11}$, Caso 12.066. Parágrafos 71 e 72. Parágrafo 92.

${ }^{186}$ Ibid., Parágrafos 93 e 94.
} 
delitos é de 1(um) e 3 (três) anos. Assim sendo, operou-se a extinção da pretensão punitiva estatal pela prescrição, com base no art. 109, VI, do CP.

No tocante ao delito descrito no art. 149 do CP, não obstante a pena máxima se consumará em abril de 2009 , forçoso é concluir pela verificação do marco prescricional pela pena em perspectiva, tendo em vista que este órgão de execução não vislumbrou maiores elementos que possibilitem o agravamento suficiente da eventual sanção aplicada ${ }^{187}$. (grifei)

Na mesma data, o Juiz Federal declarou extinta a ação penal considerando a inevitabilidade da prescrição. Segundo a CIDH, a argumentação dada pelo Juiz para extinguir a ação foi a seguinte:

[...] levando em conta que se haviam passado mais de 10 anos desde a apresentação da denúncia, que a pena máxima aplicável era de 8 anos, e que a prescrição da pena era de 12 anos, somente em caso de serem condenados a pena capital não ocorreria a prescrição. O juiz afirmou que era 'muito improvável" que fossem condenados a essa pena, razão pela qual a prescrição era 'inevitável'. Sobre esse ponto, considerou que o processo tinha 'nascido condenado ao fracasso' e destacou que com os elementos probatórios contidos na instrução criminal o caso era 'inútil'. Com base nessas considerações, assim como na 'falta de ação por parte do Estado, na política criminal e na economia processual', o juiz decidiu declarar extinta a ação penal contra Raimundo Alves da Rocha e Antonio Alves Vieira ${ }^{188}$. (grifei)

Após finalizarmos esse longo relato, podemos concluir o seguinte: as fiscalizações de abril de 1997 e março de 2000 concluíram pela existência de trabalho escravo na Fazenda Brasil Verde. A visita policial de 1989 e as fiscalizações de 1993 e 1996 encontraram "irregularidades" trabalhistas e a fiscalização de novembro de 1997 considerou que havia "algumas falhas" na referida fazenda ${ }^{189}$. Além disso, os adolescentes desaparecidos jamais foram encontrados. Mesmo diante de todas as denúncias, fiscalizações e provas colhidas, nenhum dos trabalhadores resgatados ao longo desses anos recebeu reparação adequada e nenhum dos responsáveis por submetê-los nas relatadas condições foi punido.

\footnotetext{
${ }^{187}$ Relatório n $169 / 11$, Caso 12.066. Parágrafos 71 e 72 . par. 97.

${ }^{188}$ Ibid., par. 98.

189 Disponível em: <https://www.oas.org/es/cidh/decisiones/corte/2015/12066NdeResPT.pdf〉. Acesso em: 15 nov. 2016.
} 
Devido a tantas violações sem as devidas prestações jurisdicionais, em 12 de novembro de 1998, a CPT e o CEJIL apresentaram à CIDH uma denúncia contra o Estado brasileiro "pela sua omissão e negligência em investigar diligentemente a prática de trabalho escravo na Fazenda Brasil Verde ${ }^{\prime 190}$. A seguir, examinaremos as considerações feitas pela CIDH acerca desse caso (tópico 4.1.2).

\subsubsection{Considerações da Comissão Interamericana}

A $\mathrm{CIDH}$ considerou que as informações disponíveis permitem classificar as práticas de exploração de trabalho forçado e servidão por dívidas, constatadas na Fazenda Brasil Verde, como forma contemporânea de escravidão ${ }^{191}$.

A CIDH também considerou que essas violações são de responsabilidade internacional do Estado do Brasil, pois o mesmo teve conhecimento da existência dessas práticas na região, e especificamente na Fazenda Brasil Verde desde, pelo menos, 1989. A CIDH afirmou que, não obstante o conhecimento do Estado sobre as violações a Direitos Humanos ali perpetradas, não foram adotadas medidas razoáveis de prevenção e resposta, tampouco foram fornecidas às vítimas um mecanismo judicial eficaz à proteção de seus direitos, punição dos responsáveis e obtenção de reparação adequada $^{192}$.

A CIDH concluiu pela responsabilidade internacional do Estado pelo desaparecimento dos adolescentes Iron Canuto e Luis Ferreira, tendo em vista a ausência de medidas eficazes para determinar o paradeiro dos

\footnotetext{
${ }^{190}$ Relatório n 169/11, Caso 12.066. Parágrafo 1.

191 Disponível em: 〈https://www.oas.org/es/cidh/decisiones/corte/2015/12066NdeResPT.pdf〉. Acesso em: 15 nov. 2016.

192 Disponível em: <https://www.oas.org/es/cidh/decisiones/corte/2015/12066NdeResPT.pdf〉. Acesso em: 15 nov. 2016.
} 
rapazes após denúncia apresentada às autoridades estatais em 21 de dezembro de $1988^{193}$.

Ao pronunciar-se sobre o mérito, a CIDH concluiu que o Brasil era responsável internacionalmente pelas seguintes violações ${ }^{194}$ :

- violação dos direitos consagrados nos artigos $6^{\circ}$ (proibição da escravidão e da servidão), $5^{\circ}$ (integridade pessoal), $7^{\circ}$ (liberdade pessoal), 22 (direito de circulação), $8^{\circ}$ (garantia judicial) e 25 (proteção judicial) da $\mathrm{CADH}$ em prejuízo dos trabalhadores encontrados nas físcalizações de 1993, 1996, 1997 e 2000 na Fazenda Brasil Verde;

- violação dos direitos consagrados nos artigos I (Direito à vida, à liberdade, à segurança, à integridade pessoal), II (Direito à igualdade perante a lei), XIV (Direito ao trabalho e a uma justa retribuição), VIII (Direito de residência e trânsito), XVIII (Direito aos benefícios da Cultura), todos da Declaração Americana dos Direitos e Deveres do Homem e, a partir de setembro de 1992, nos artigos 8 (garantia judicial) e 25 (proteção judicial), em relação com o artigo 1.1, todos da $\mathrm{CADH}$, em prejuízo de Iron Canuto da Silva e Luis Ferreira da Cruz, bem como de seus familiares;

- violação do artigo I (Direito à vida, à liberdade, à segurança, à integridade pessoal) da Declaração Americana e, a partir de 25 de setembro de 1992, do artigo $5^{\circ}$ (Direito à integridade pessoal) da CADH em prejuízo dos familiares de Iron Canuto da Silva e Luis Ferreira da Cruz;

- violação dos artigos I (Direito à vida, à liberdade, à segurança, à integridade pessoal), VII (Direito à constituição e proteção da família) e XIV (Direito ao trabalho e a uma justa retribuição) da Declaração Americana e, a partir de 25 de setembro de 1992, dos artigos $7^{\circ}$ (Direito à liberdade pessoal), $5^{\circ}$ (Direito à integridade pessoal), $4^{\circ}$ (Direito à vida), $3^{\circ}$ (Direito ao reconhecimento da personalidade jurídica) e 19 (Direitos da criança) da $\mathrm{CADH}$, em relação com os artigos $8^{\circ}$ (garantias judiciais), 25

\footnotetext{
193 Ibid., Acesso em: 15 nov. 2016.

${ }^{194}$ Relatório n¹69/11, Caso 12.066. Parágrafos 71-72.
} 
(proteção judicial) e 1.1 (Obrigação de respeitar os direitos e liberdades reconhecidos na Convenção) da mesma, em detrimento de Iron Canuto da Silva e Luis Ferreira da Cruz.

- não adoção de medidas suficientes e eficazes a garantir, sem discriminação, os direitos dos trabalhadores encontrados nas fiscalizações de 1993, 1996, 1997 e 2000, em conformidade com o artigo 1.1 (Obrigação de respeitar os direitos e liberdades reconhecidos na Convenção) da CADH, em relação com os direitos previstos nos artigos $6^{\circ}$ (proibição da escravidão e da servidão), $5^{\circ}$ (Direito à integridade pessoal), $7^{\circ}$ (Direito à liberdade pessoal), 22 (Direito de circulação e residência), $8^{\circ}$ (garantias judiciais) e 25 (proteção judicial) da mesma.

- não adoção de medidas em conformidades com o artigo II (Direito à igualdade perante a lei) da Declaração Americana, em relação com o artigo XVIII (Direito aos benefícios da cultura) da mesma e, a partir de 25 de setembro de 1992, com o artigo 1.1 (Obrigação de respeitar os direitos e liberdades reconhecidos na Convenção) da $\mathrm{CADH}$, combinado com os $\operatorname{artigos} 8^{\circ}$ (garantias judiciais) e 25 (proteção judicial) da mesma, em prejuízo de Iron Canuto da Silva, Luis Ferreira da Cruz, Adailton Martins dos Reis e José Soriano da Costa, bem como dos familiares dos dois primeiros.

- a aplicação da figura da "prescrição" no caso em comento violou os artigos 8.1 (garantias judiciais) e 25.1 (proteção judicial), em relação com as obrigações previstas no artigo 1.1 (Obrigação de respeitar os direitos e liberdades reconhecidos na Convenção) e $2^{\circ}$ (Dever de adotar disposições de direito interno), todos da $\mathrm{CADH}$, em prejuízo de Iron Canuto da Silva, Luis Ferreira da Cruz, Adailton Martins dos Reis, José Soriano da Costa e de todos os trabalhadores que foram encontrados na Fazenda Brasil Verde durante as fiscalizações de 1997.

O relatório de admissibilidade e mérito foi notificado ao Estado em 4 de janeiro de 2012 e lhe foi concedido um prazo de dois meses para que 
informasse sobre o cumprimento das recomendações feitas pela $\mathrm{CIDH}$. Após 10 prorrogações terem sido concedidas, o Estado não avançou de maneira concreta no cumprimento das recomendações do relatório da $\mathrm{CIDH}^{195}$, o que demonstra, em nossa opinião, seu descompromisso em combater de forma eficaz o trabalho escravo.

Não obstante o Estado tenha apresentado informações sobre as medidas adotadas para enfrentar o trabalho escravo desde 1995 e, com mais compromisso, desde 2003, não avançou em relação ao cumprimento das recomendações para reparar adequadamente as vítimas tanto moral quanto formalmente. Tampouco apresentou informações sobre as medidas tomadas no que tange às recomendações para investigação dos fatos do caso ${ }^{196}$.

Diante do não cumprimento das recomendações da CIDH pelo Estado e das recentes dificuldades para se progredir no enfrentamento ao trabalho escravo, vistas no tópico anterior, a Comissão decidiu submeter o Caso Fazenda Brasil Verde à Corte Interamericana de Direitos Humanos.

A CIDH submeteu à Corte, especificamente, as ações e omissões estatais que ocorreram ou continuaram a ocorrer posteriormente a 10 de dezembro de 1998, data em que o Brasil reconheceu a competência jurisdicional da Corte. Dentre essas ações e omissões, figuram ${ }^{197}$ :

- a situação de trabalho forçado e servidão por dívidas análogas à escravidão a partir de 10 de dezembro de 1998;

- as ações e omissões que levaram à situação de impunidade da totalidade dos fatos do caso e que continua vigente até a presente data;

- os desaparecimentos de Iron Canuto e Luis Ferreira, cujos paradeiros são até hoje desconhecidos.

\footnotetext{
195 Disponível em: <https://www.oas.org/es/cidh/decisiones/corte/2015/12066NdeResPT.pdf>. Acesso em: 15 nov. 2016.

${ }^{196}$ Ibid., Acesso em: 15 nov. 2016.

197 Disponível em: <https://www.oas.org/es/cidh/decisiones/corte/2015/12066NdeResPT.pdf>. Acesso em: 15 nov. 2016.
} 
A Comissão solicitou à Corte que ordene as seguintes medidas de reparação, já recomendadas ao Estado e por ele não adotadas ${ }^{198}$ :

1. reparar adequadamente as violações de direitos humanos nos aspectos materiais e morais. $\mathrm{O}$ Estado deve assegurar que sejam restituídos às vítimas os salários devidos pelo trabalho realizado e também os montantes ilegalmente subtraídos dos mesmos.

2. investigar os fatos relacionados com as violações de direitos humanos relatadas no que tange ao trabalho escravo e realizar as investigações de forma imparcial, eficaz e dentro de um prazo razoável, com o objetivo de esclarecer os fatos de forma completa, identificar os responsáveis e impor as punições pertinentes.

3. levar a cabo uma investigação dos fatos relacionados com o desaparecimento de Iron Canuto e Luis Ferreira e fazer as investigações imparcial e eficazmente, dentro de um prazo razoável, no intuito de esclarecer os fatos de forma completa, identificar os responsáveis e estabelecer as devidas punições.

4. providenciar as medidas administrativas, disciplinares ou penais pertinentes relativas às ações ou omissões dos funcionários estatais que contribuíram para a negação de justiça e impunidade em que se encontram os fatos do caso. É importante ressaltar que foram abertos processos administrativos para a investigação dos desaparecimentos; que foram abertos processos administrativos e trabalhistas para a investigação de trabalho escravo; e que prescreveu a única investigação penal aberta em relação com esse delito.

5. estabelecer um mecanismo que facilite a localização das vítimas de trabalho escravo, especialmente das vítimas do presente caso;

6. continuar a implementar políticas públicas, bem como medidas legislativas e de outra natureza de erradicação do trabalho escravo. O Estado deve monitorar a aplicação de tais medidas e garantir a punição de pessoas responsáveis pelo trabalho escravo em todos os níveis.

7. fortalecer o sistema jurídico e criar mecanismos de coordenação entre a jurisdição penal e a jurisdição trabalhista para superar os vazios existentes na investigação, julgamento e punição das pessoas responsáveis pela exploração de trabalho escravo;

198 As medidas de reparação elencadas foram estabelecidas no Relatório de admissibilidade e mérito, Relatório $\mathrm{N}^{\circ} 169 / 11$ da CIDH. Foram reiteradas no documento em que a Comissão submete o Caso Fazenda Brasil Verde vs. Brasil à jurisdição da Corte, datado de 4 de março de 2015.

Ibid., Acesso em: 15 nov. 2016. 
8. Velar pelo absoluto cumprimento das leis trabalhistas, em especial às relativas a jornada de trabalho e ao pagamento em igualdade com os demais trabalhadores assalariados.

9. adotar as medidas necessárias para promover a conscientização da população nacional e dos funcionários do Estado.

A CIDH destacou, ainda, que o caso Fazenda Brasil Verde envolve questões de ordem pública interamericana. Mais especificamente, o caso representa uma oportunidade para que a Corte Interamericana desenvolva jurisprudência sobre o trabalho escravo contemporâneo. A Corte poderá desenvolver as circunstâncias em que um Estado pode ser responsabilizado internacionalmente pela existência desse tipo de prática, bem como o alcance do dever de prevenção de atos dessa natureza por particulares e do dever de investigar e punir tais violações ${ }^{199}$.

\subsection{Expectativas em relação à Sentença}

Em vista de todo o exposto pela CIDH, a Corte IDH recebeu o Caso Fazenda Brasil Verde em 4 de março de $2015^{200}$. Nos dias 18 e 19 de fevereiro de 2016 foi realizada a audiência pública perante a Corte, em San José, na Costa Rica ${ }^{201}$. Diante disso, o presente tópico terá, como objetivo, expor as alegações feitas pelos representantes das vítimas (tópico 4.2.1.) e pelo Estado (tópico 4.2.2) nessa audiência, bem como as expectativas dos mesmos em relação à sentença. Por fim, faremos um breve comentário acerca de nossas próprias expectativas (tópico 4.2.3.).

\footnotetext{
199 Informações obtidas por meio do documento em que a Comissão submete o Caso Fazenda Brasil Verde vs. Brasil à jurisdição da Corte, datado de 4 de março de 2015. Disponível em: <https://www.oas.org/es/cidh/decisiones/corte/2015/12066NdeResPT.pdf〉. Acesso em: 15 nov. 2016.

${ }^{200}$ Trâmite do Caso Fazenda Brasil Verde. Disponível em:

$\langle$ http://www.corteidh.or.cr/docs/tramite/trabajadores_de_la_hacienda_brasil_verde.pdf $\rangle$. Acesso em: 20 nov. 2016.

${ }^{201}$ Trâmite do Caso Fazenda Brasil Verde. Disponível em:

$\langle$ http://www.corteidh.or.cr/docs/tramite/trabajadores_de_la_hacienda_brasil_verde.pdf $\rangle$. Acesso em: 16 nov. 2016.
} 


\subsubsection{Considerações dos representantes das vítimas}

Em relação às alegações finais feitas oralmente pelos representantes das vítimas na audiência pública, os mesmos afirmaram que o Estado foi responsável pela violação aos direitos à igualdade, à proteção judicial e à vida livre de qualquer forma de exploração humana, dentro do alcance do Art. $6^{\circ}$ da $\mathrm{CADH}^{202}$. Explicaram que a violação desses direitos ocorreu em decorrência da tolerância, complacência, indiferença, negligência e atos de imperícia do Estado em relação à situação de extrema vulnerabilidade de mais de 300 trabalhadores encontrados na Fazenda Brasil Verde. Segundo eles, a responsabilidade do Estado está estabelecida pela falta de prevenção, proteção e reparação.

Em relação à falta de prevenção aos danos a direitos fundamentais dos trabalhadores, afirmaram que o Estado teve conhecimento por meio de denúncias específicas, bem como por pedidos de agentes estatais, sobre a existência da situação de risco extremo dos trabalhadores, mas o Estado se omitiu mesmo assim.

Em relação à falta de proteção e garantia de Direitos, afirmaram que há uma série de ausências no que tange ao dever de investigar, faltando a devida diligência, de modo a prejudicar os processos que foram futuramente instaurados, principalmente em relação aos desaparecimentos forçados.

Os representantes das vítimas informaram que nenhuma delas recebeu reparações específicas e adequadas, ressaltando, ainda, que a falta de reparação dificulta a saída dessas pessoas do círculo vicioso de trabalho escravo.

Adicionaram que a violação ao Art. $6^{\circ}$ restou comprovada em função de provas diretas que demonstram um padrão de tratamento de pessoas em formas análogas à escravidão. Essas formas foram constatadas como um

\footnotetext{
202 Audiência Pública Caso Trabalhadores da Fazenda Brasil Verde vs. Brasil Parte 3. Alegações Finais dos Representantes das Vítimas. Min: de 1hr08min59seg a 1hrs39min18seg. Disponível em: <https://vimeo.com/156624613>. Acesso em: 20 nov. 2016.
} 
modus operandi específico na Fazenda Brasil Verde, as quais contrariam o disposto no artigo $6^{\circ}$ da $\mathrm{CADH}$.

Finalizaram afirmando que há deficiências muito significantes na atuação dos órgãos do Estado, que tornam difícil a erradicação desse flagelo social que é a exploração de trabalho escravo. Os representantes das vítimas esperam que, a partir da decisão da Corte, se derivem uma série de pilares, necessários para reorientarem a atuação estatal, darem respostas específicas às vítimas e inibirem as condutas recorrentes de trabalho escravo, de modo a atacarem o pilar da impunidade e da ganância econômica, fundantes da perpetuação do trabalho escravo.

Segundo Xavier Plassat ${ }^{203}$, a sentença provavelmente determinará a reparação dos danos sofridos por mais de 300 trabalhadores sucessivamente explorados na Fazenda Brasil Verde. Segundo ele, os peticionários esperam que a Corte julgue procedentes os requerimentos da CIDH. Acrescentou que a Corte provavelmente deverá enunciar importantes parâmetros para o enfrentamento ao trabalho escravo, válido para todos os países da OEA. A Corte terá a oportunidade de desenvolver as circunstâncias em que o estado poderá ser responsabilizado a nível internacional por esse tipo de prática. A Corte terá, ainda, a chance de determinar o alcance do dever de prevenir o cometimento de atos dessa natureza por particulares e do dever de investigar e punir tais violações. Xavier considerou que, do ponto de vista dos peticionários, a audiência desenvolveu-se da "melhor maneira possível”, de modo que está confiante acerca de uma sentença responsiva às violações suscitadas pela CIDH e pelos peticionários.

\footnotetext{
${ }^{203}$ A respeito da audiência, Xavier Plassat, representante da peticionária CPT, escreveu um breve artigo sobre suas impressões e expectativas. PLASSAT, Xavier. Caso de trabalho escravo faz OEA pôr Brasil no banco dos réus. 01 de março de 2016. Disponível em: $<$ http://reporterbrasil.org.br/2016/03/caso-de-trabalho-escravo-faz-oea-por-brasil-no-banco-dosreus/>. Acesso em: 16 nov. 2016.

Já quanto à expectativa dos peticionários, o Frei Xavier Plassat concedeu uma entrevista ao Instituto Humanitas Unisinos e outra à Agência Brasil, nas quais forneceu alguns esclarecimentos. As mencionadas entrevistas estão disponíveis nos seguintes sítios eletrônicos: Disponível em: <http://www.ihu.unisinos.br/entrevistas/552215-trabalho-escravo-no-brasil-os-riscos-de-passar-devitrine-a-vidraca-entrevista-especial-com-xavier-plassat>. Acesso em: 15 nov. 2016. Disponível em: <http://agenciabrasil.ebc.com.br/direitos-humanos/noticia/2016-02/oea-vai-julgarresponsabilidade-do-brasil-em-caso-de-trabalho>. Acesso em: 18 nov. 2016.
} 
Todavia, em relação a questões mais específicas, Xavier informou que os peticionários concordam com o argumento do Estado de que todos os fatos alegados e ocorridos antes de 1998 saem da competência da Corte. Contudo, ressalta que os fatos ocorridos anteriormente podem ser analisados no que tange aos artigos $8^{\circ}$ e 25 da $\mathrm{CADH}$, tendo em vista que o Estado brasileiro permaneceu inerte em relação à reparação desses trabalhadores e não ofereceu medidas judiciais eficazes, assim como não investigou adequadamente o desaparecimento dos dois adolescentes ${ }^{204}$. Acrescentou que esperam que a Corte aceite a denúncia acerca da omissão do Estado no que tange à apuração das denúncias feitas contra a Fazenda Brasil Verde e que recomende a implementação de políticas públicas capazes de impedir a reincidência desses trabalhadores vulneráveis a condições análogas a de escravo. Por fim, informa que os peticionários esperam que, a partir da sentença, o Estado brasileiro torne a submissão de alguém ao trabalho análogo ao de escravo um crime imprescritível ${ }^{205}$.

Por fim, Xavier afirmou que:

Essa é a primeira vez que a Corte IDH irá se pronunciar sobre um caso de trabalho escravo. Isso confere a este caso uma importância ainda maior, pois iremos criar uma jurisprudência, ajudando a clarear para todos os países membros da OEA o que é trabalho escravo contemporâneo, sua relação com tráfico e em que consiste a responsabilidade dos estados no seu enfrentamento ${ }^{206}$.

\subsubsection{Considerações do representante do Estado}

Durante a audiência pública, a defesa oral do Estado do Brasil foi realizada por Boni Soares, diretor do Departamento Internacional da

\footnotetext{
${ }^{204}$ Instituto Humanitas Unisinos. Disponível em: <http://www.ihu.unisinos.br/entrevistas/552215trabalho-escravo-no-brasil-os-riscos-de-passar-de-vitrine-a-vidraca-entrevista-especial-comxavier-plassat>. Acesso em: 18 nov. 2016.

205 Informações retiradas de entrevista concedida à Agência Brasil. Disponível em: $<$ http://agenciabrasil.ebc.com.br/direitos-humanos/noticia/2016-02/oea-vai-julgarresponsabilidade-do-brasil-em-caso-de-trabalho>. Acesso em: 18 nov. 2016.

206 Disponível em: <http://www.ihu.unisinos.br/entrevistas/552215-trabalho-escravo-no-brasil-osriscos-de-passar-de-vitrine-a-vidraca-entrevista-especial-com-xavier-plassat>. Acesso em: 18 nov. 2016.
} 
Procuradoria-Geral da União ${ }^{207}$. Ao longo de sua argumentação de defesa, reconheceu que o Brasil ainda está inserido em "um contexto infeliz de exploração de mão-de-obra escrava", e que firmou o compromisso internacional de empreender esforços para seguir enfrentando o trabalho escravo. Citou alguns dos mecanismos desenvolvidos desde 1995 para erradicar essa prática, já abordados nesse trabalho, e lembrou o reconhecimento internacional recebido pelo país por essas medidas terem se tornado parâmetros a serem seguidos pelos demais países. Acrescentou que o Brasil concorda que existem desafios significativos a respeito do enfrentamento do trabalho escravo contemporâneo, mas alerta que o Estado vem, ao mesmo tempo, desenvolvendo grandes soluções para enfrentar tais desafios. Adicionou que o Estado continuará gerando grandes soluções, independentemente da decisão da Corte.

Ressaltou, porém, que a definição desse julgamento deve observar os atores concretos do caso Fazenda Brasil Verde, as vítimas específicas e determinadas e os violadores comprovados dos Direitos Humanos. Traçou comentários no sentido de a Honorável Corte não ter competência para julgar o Estado com base apenas na realidade contextual em que o trabalho escravo ocorre no Brasil. Boni Soares afirmou acreditar que a Corte proferirá julgamento com base, sobretudo, nas condutas comprovadas desses atores e não no contexto geral.

A respeito dos fatos, Boni Soares abordou a questão conceitual de escravidão. Afirmou que, segundo as conceituações enunciadas pelo perito, o elemento comum entre trabalho forçado e servidão por dívidas é a privação de liberdade. Alegou que não há provas contundentes de que, após 10 de dezembro de 1998, tenha havido privação da liberdade de algum trabalhador na Fazenda Brasil Verde. Segundo ele, tão somente foram constatadas condições degradantes e jornada exaustiva, as quais não

\footnotetext{
207 Audiência Pública Caso Trabalhadores da Fazenda Brasil Verde vs. Brasil Parte 3. Alegações Finais do Estado de $1 \mathrm{hr} 39 \mathrm{~min} 32 \mathrm{seg}$ a $2 \mathrm{hrs} 08 \mathrm{~min} 31 \mathrm{seg}$. Disponível em: <https://vimeo.com/156624613>. Acesso em: 17 nov. 2016.
} 
configuram trabalho escravo. Segundo Boni, para preservar a integridade física desses trabalhadores, os mesmos foram "resgatados pela fiscalização", mas não por estarem em situação de trabalho escravo - o que demonstrou uma contradição em seu argumento. Ressaltou que, os próprios representantes das vítimas alegam a existência de alta rotatividade de trabalhadores, e que os mesmos eram contratados para trabalhar temporariamente. Nesse sentido, pergunta como poderia haver restrição de liberdade se os trabalhadores permaneciam por pouco tempo na fazenda.

Alegou que o Estado não está perante a Corte para se defender sobre a existência de trabalho escravo em seu território, mas sim das violações específicas cometidas por pessoas determinadas, em um momento certo, após 10 de dezembro de 1998. Em relação às alegadas violações aos artigos $8^{\circ}$ e 25 da $\mathrm{CADH}$, alega que as mesmas deveriam ter ocorrido em data posterior ao reconhecimento de competência da Corte, o que, segundo Boni Soares, não teria ocorrido.

O Estado concordou sobre a importância de a Corte estabelecer jurisprudência interamericana acerca do artigo $6^{\circ}$ da $\mathrm{CADH}$, mas ressaltou que isso precisa se dar a partir de um caso em que tenha ocorrido comprovadamente a escravidão, servidão por dívida ou trabalho forçado, o que não se configurou, segundo ele, no Caso Brasil Verde. Acrescentou, ainda, que isso deve ser feito respeitando os limites de jurisdição da Corte.

Em entrevista à Agência Brasil, Boni Soares informou que a expectativa do Estado é a de que a Corte exerça um julgamento técnico, imparcial, à luz das provas e dos argumentos apresentados. Caso isso se concretize, em sua visão, a sentença da Corte será muito diferente do relatório emitido pela Comissão em $2011^{208}$.

Nos dias 6 e 7 de junho foram realizadas diligências in loco por funcionários da Corte e em 28 de junho de 2016 as partes enviaram suas

\footnotetext{
208 Disponível em: <http://agenciabrasil.ebc.com.br/direitos-humanos/noticia/2016-02/brasilespera-decisao-favoravel-da-oea-em-julgamento-sobre-trabalho>. Acesso em: 17 nov. 2016.
} 
alegações finais por escrito ${ }^{209}$. A expectativa é de que a sentença seja proferida ainda no ano de 2016.

\subsubsection{Nossa expectativa}

Diante de todo o exposto, esse tópico final visa a traçar breves comentários acerca do que esperamos do julgamento da Corte. É importante destacar, contudo, que foge ao escopo desse tópico analisar de forma profunda as violações a cada direito previsto na $\mathrm{CADH}$, constatadas pela CIDH no Caso Fazenda Brasil Verde.

Primeiramente, tendo em vista que os fatos analisados no caso são extensos, configurados entre 1988 e 2000 e que, estão em questão os desdobramentos de 6 fiscalizações realizadas entre 1989 e 2000, resta evidente que a Corte Interamericana de Direitos Humanos precisará ser muito minuciosa quanto à análise do caso. Será necessário que a mesma esclareça o alcance de sua competência em relação aos fatos comprovados, especialmente devido ao reconhecimento de sua competência pelo Brasil apenas ter ocorrido em dezembro de 1998. Portanto, aguardamos uma sentença que seja clara ao determinar a competência da Corte em relação ao julgamento de cada violação de direito consagrado na $\mathrm{CADH}$.

Em segundo lugar, esperamos que a sentença considere que a omissão estatal na investigação do desaparecimento dos dois adolescentes é condenável e atribua essa responsabilidade internacional ao Estado. Acreditamos que a Corte se manifestará nesse sentido, pois já proferiu inúmeros julgados em que considerou que o desaparecimento forçado é

\footnotetext{
${ }^{209}$ Informação disponível na página da Corte IDH sobre o trâmite do Caso Fazenda Brasil Verde. Disponível em: $\langle$ http://www.corteidh.or.cr/docs/tramite/trabajadores_de_la_hacienda_brasil_verde.pdf $>$. Acesso em: 16 nov. 2016.
} 
uma "violação múltipla, continuada e permanente de direitos humanos"

A Corte já se manifestou no seguinte sentido:

(...) a jurisprudência deste Tribunal foi precursora da consolidação de uma perspectiva abrangente da gravidade e do caráter continuado ou permanente da figura do desaparecimento forçado de pessoas, na qual o ato de desaparecimento e sua execução se iniciam com a privação da liberdade da pessoa e a subsequente falta de informação sobre seu destino, e permanece enquanto não se conheça o paradeiro da pessoa desaparecida e se determine com certeza sua identidade. Em conformidade com todo o exposto, a Corte reiterou que o desaparecimento forçado constitui uma violação múltipla de vários direitos protegidos pela Convenção Americana, que coloca a vítima em um estado de completa desproteção e acarreta outras violações conexas $(. . .)^{211}$.

Uma importante ressalva é que, nos casos em que a Corte se manifestou nesse sentido, os desaparecimentos forçados foram perpetrados por agentes estatais em um contexto em que tais desaparecimentos eram reiterados. Contudo, poderíamos considerar a jurisprudência também já consolidada da Corte no sentido de o Estado poder ser responsável por violações a direitos humanos perpetradas por terceiros. A Corte IDH já estabeleceu que é "suficiente demonstrar que houve apoio ou tolerância do poder público na violação dos direitos reconhecidos na Convenção" ${ }^{212}$. A Corte explica que a responsabilidade internacional do Estado é comprometida quando o mesmo não realiza as diligências necessárias, de acordo com seu direito interno, para identificar e sancionar os autores dessas violações. As diferentes fiscalizações realizadas na Fazenda Brasil Verde, bem como o envolvimento de diferentes atores estatais, geraram resultados insuficientes no contexto de exploração ali existente, e a falta de medidas mais assertivas em busca de esclarecimentos concretos acerca do desaparecimento dos dois adolescentes, configura, em nosso entendimento, tolerância do poder público diante das violações, além da ineficácia no dever de investigar.

\footnotetext{
${ }^{210}$ CORTE IDH. Caso Gomes Lund e outros ("Guerrilha do Araguaia) vs. Brasil. Sentença de 24 de novembro de 2010. Parágrafos 102-108. CORTE IDH. Caso Ríos y otros vs. Venezuela. Sentença de 28 de janeiro de 2009. Parágrafo 137.

${ }^{211}$ Ibid., Parágrafo 103.

${ }^{212}$ CORTE IDH. Caso Paniangua Morales e outros ("Kombi Branca") vs. Guatemala. Sentença de 8 de março de 1998. Parágrao 91.
} 
A Corte já firmou jurisprudência no sentido de o Estado poder ser responsabilizado pela falta de prevenção, investigação e sanção de toda violação de Direitos Humanos, mesmo que perpetradas por terceiros, bem como por ações ou omissões de qualquer autoridade pública em relação a alguma violação ${ }^{213}$. Nesse sentido, o Estado pode ser responsabilizado pela submissão dos trabalhadores resgatados após 1998 a condições análogas à escravidão, apesar dessas violações terem sido perpetradas por terceiros. A ineficácia do Estado na prevenção, investigação e sanção permitiram a continuidade dos atos de violação através dos resultados insuficientes das medidas e procedimentos adotados.

No Relatório de Admissibilidade e Mérito no Caso Brasil Verde, a CIDH desagregou os critérios já desenvolvidos pela Corte para responsabilizar o Estado por violações cometidas por terceiros da seguinte forma: (i) a existência de um risco real e imediato; (ii) o conhecimento que o Estado tinha sobre o risco; (iii) a situação particular das pessoas afetadas; e (iv) as possibilidades razoáveis de prevenção ou se sabia ou devesse saber $^{214}$.

Tendo em vista esses critérios, a contextualização em que se insere a exploração do trabalho escravo no Brasil e os fatos expostos nesse trabalho, é possível considerar que o Estado brasileiro: (i) conhecia o padrão de exploração e o risco específico em que estavam inseridos os trabalhadores daquela região; (ii) conhecia as denúncias feitas em relação às fazendas ali

\footnotetext{
${ }^{213}$ CORTE IDH. Caso Massacre de Mapiripán vs. Colômbia. Sentença de 15 de setembro de 2005. Parágrafo 111; CORTE IDH. Caso Velásquez Rodríguez vs. Honduras. Sentença de 29 de julho de 1988. Parágrafos 166 e 176; CORTE IDH. Caso de La Masacre de Pueblo Bello vs. Colombia. Sentença de 31 de janeiro de 2006. Parágrafos 111 e 123-126.

Podemos também mencionar o caso Campo Algodonero vs. México, em que a Corte afirmou que, devido à falta de provas, não é possível imputar ao Estado a responsabilidade pela violação aos artigos 4, 5 e $7 \mathrm{CADH}$, mas sim pela violação aos artigos $8^{\circ}$ e $25 \mathrm{CADH}$, já que tinha conhecimento sobre a situação de vulnerabilidade das mulheres na cidade de Juarez. Aqui podemos fazer um paralelo com o Caso Fazenda Brasil Verde, em que o Estado tinha conhecimento sobre a prática reiterada de submissão dos trabalhadores a condições análogas a de escravos na região do Pará e não tomou as medidas adequadas para erradicar essa prática nem para investigar os atos já ocorridos. Ver: CORTE IDH. Caso González y otras (Campo Algodonero) vs. México. Sentença de 16 de novembro de 2009. parágrafos 242 e 258.

${ }^{214}$ Relatório n`169/11, Caso 12.066 Admissibilidade e Mérito: Fazenda Brasil Verde vs. Brasil. OEA/Ser/L/V/II.143. Doc. 53. 3 de novembro de 2011. Parágrafo 153-160.
} 
estabelecidas, em especial, à Fazenda Brasil Verde; e (iii) tinha a obrigação de adotar medidas específicas e eficazes e não o fez, de modo que descumpriu seus deveres de prevenção e repressão. Ademais, as comprovadas vítimas do caso não receberam reparação, de modo que o Estado também descumpriu seu deve de reparar.

Esperamos, portanto, que a Corte considere que os procedimentos abertos para investigar as violações de Direitos Humanos ocorridas na Fazenda Brasil Verde entre 1988 e 2000 foram ineficazes e não tramitaram em um prazo razoável, o que violou os arts. $8^{\circ}$ e 25 c/c 1.1 e 2 da CADH. Desde sua primeira sentença, a Corte IDH destacou a importância do dever do Estado de investigar e punir violações de Direitos Humanos ${ }^{215}$. Nesse sentido, expressou:

\begin{abstract}
O artigo 25 em relação com o artigo 1.1 da Convenção Americana, obriga o Estado a garantir a toda pessoa o acesso à administração da justiça e, em particular, a um recurso simples e rápido para conseguir, dentre outros resultados, que os responsáveis pelas violações dos direitos humanos sejam julgados e para obter uma reparação pelo dano sofrido (...) O Artigo 24 constitui um dos pilares básicos, não somente da Convenção Americana, senão do próprio estado de direito numa sociedade democrática (...). Esse artigo tem relação direta com o artigo 8.1 que consagra o direito de toda pessoa a ser ouvida com as devidas garantias (...) para a determinação de seus direitos de qualquer natureza ${ }^{216}$.
\end{abstract}

Considerando os desafios enfrentados até o momento no combate ao trabalho escravo contemporâneo, é de extrema importância que a Corte estabeleça um conceito rígido e claro do mesmo. Faz-se necessária a delimitação do alcance do art. $6^{\circ}$ da $\mathrm{CADH}$, de modo que o mesmo possa ser utilizado como parâmetro para os demais Estados membros da OEA, bem como sirva de norte para orientar as medidas a serem adotadas pelo Brasil a partir desse novo marco que será o julgamento do Caso Fazenda Brasil Verde.

\footnotetext{
${ }^{215}$ CORTE IDH. Caso Velásquez Rodríguez vs. Honduras. Sentença de 29 de julho de 1988. Parágrafo 166.

${ }^{216}$ CORTE IDH. Caso Velásquez Rodriguez vs. Honduras. Sentença de 26 de junho de 1987. Parágrafo 91; Caso Loayaza Tamayo vs. Peru. Reparações (artigo 63.1 Convenção Americana sobre Direitos Humanos). Sentença de 27 de novembro de 1998. Parágrafo 169.
} 
É importante destacar que, conforme mencionado no tópico 2.1 desse trabalho, no caso Massacres de Ituango vs. Colômbia ${ }^{217}$, a Corte teve a oportunidade de se manifestar acerca do conceito de trabalho forçado. Interpretou o artigo $6^{\circ}$ da CADH à luz da Convenção N. 29 da OIT, reiterando os elementos "ameaça de punição" e "ausência de consentimento" como critérios a serem utilizados como parâmetro de identificação do trabalho forçado. Acrescentou, ainda, um novo elemento: a violação deve atribuível a agentes estatais, tanto por sua participação direta quanto por sua aquiescência. Contudo, o trabalho escravo não era a principal temática abordada no caso, de modo que a Corte não se estendeu muito acerca desse tipo de violação.

Já no Caso Massacres do Rio Negro vs. Guatemala ${ }^{218}$ a Corte IDH também considerou violado o artigo $6^{\circ} \mathrm{CADH}$, mas não aproveitou a oportunidade para tecer nenhum comentário relevante sobre esse tipo de violação ou estabeleceu um conceito claro. Consideramos que essa foi uma falha da Corte, tendo em vista que esse caso ocorreu após o julgamento do Massacres de Ituango vs. Colômbia, de modo que a Corte poderia ter aprofundado, mesmo que de forma breve, sua recente interpretação acerca do Art $6^{\circ} \mathrm{CADH}$. Diante disso, percebemos que ainda há um longo caminho a ser explorado pela Corte em relação à delimitação do alcance do referido artigo da CADH.

Ainda dentro dessa perspectiva, esperamos que a Corte apresente fortes recomendações ao Brasil, principalmente em relação à elaboração de uma lei determinando que a competência para investigar, julgar e punir crime de redução à condição análoga à de escravo seja de competência federal. Acreditamos que o poder exercido localmente pelos proprietários de fazendas infelizmente dificulta, em diversas formas, a investigação e punição dos responsáveis, seja pela corrupção ou mesmo pelo medo. Além

217 CORTE IDH. Caso Massacres de Ituango vs. Colombia. Sentença de 1 de julho de 2006. parágrafos 145-168.

${ }_{218}$ CORTE IDH. Caso Massacres do Rio Negro vs. Guatemala. Sentença de 4 de setembro de 2012. parágrafos 136-150. 
disso, pensamos que a determinação de competência federal em lei possibilitaria maior celeridade processual, evitando inclusive o uso de estratégias indevidas em busca da prescrição.

Em relação à proposta da CIDH e dos peticionários de tornar imprescritível o crime de trabalho escravo, consideramos que a mesma merece um cuidado especial. A CIDH, em seu relatório, traz à análise o seguinte entendimento da Corte IDH:

\begin{abstract}
A prescrição em matéria penal determina a extinção da pretensão punitiva pelo transcurso do tempo, e geralmente, limita o poder punitivo do Estado para perseguir a conduta ilícita e sancionar seus autores. Esta é uma garantia que deve ser observada devidamente pelo julgador para todo imputado de um crime. Não obstante, a prescrição da ação penal é inadmissível e inaplicável quando se trata de violações muito graves aos direitos humanos nos termos do Direito Internacional. A jurisprudência constante e uniforme da Corte assim o estabeleceu $^{219}$.
\end{abstract}

Contudo, acreditamos que, em relação aos fatos do presente caso, o Estado dificilmente reabrirá os processos instaurados e deixará de aplicar a figura da prescrição, sob argumentos como o da segurança jurídica e do devido processo legal. Em nosso entendimento, seria possível que o Estado tomasse iniciativas no sentido de propor um projeto de Lei ou de Emenda Constitucional determinando a imprescritibilidade dos crimes que violam gravemente os Direitos Humanos, com efeitos ex nunc. Contudo, consideramos que, se os conflitos jurisdicionais e atrasos no sistema judiciário não forem solucionados, pouco adiantará estabelecer a imprescritibilidade desse crime.

Esperamos que a Corte sugira novas medidas precisas de prevenção ao trabalho escravo contemporâneo e que, a partir da Sentença, o Estado brasileiro empreenda todos os seus esforços para o retorno da publicação da Lista Suja, para o reforço dos Grupos de Fiscalização Móvel e para a criação de mecanismos de não reincidência.

\footnotetext{
${ }^{219}$ CORTE IDH. Caso Almonacid Arellano vs. Chile. Exceções Preliminares, Mérito, Reparações e Custas. Sentença de 26 de setembro de 2006. Parágrafo 110.
} 
Aguardamos, ainda, uma manifestação da Corte acerca da Emenda Constitucional n. 81 e uma recomendação para a não restrição do conceito de trabalho escravo previsto no artigo 149 do Código Penal e sugira uma rápida regulamentação para que a Emenda possa ser aplicada.

Os representantes das vítimas do Caso Fazenda Brasil Verde encerraram suas alegações finais na Audiência Pública perante a Corte com a declaração de um trabalhador resgatado de condições análogas à escravidão e encerramos o presente trabalho com o mesmo apelo:

Eu espero que existam pessoas que possam tomar providências para que outras pessoas não tenham que sofrer o que a gente sofreu lá dentro - Francisco de Assis Felix, declaração de 8 de maio de $2015^{220}$.

Assim como o acordo de Solução Amistosa no Caso José Pereira foi um relevante marco para o enfrentamento ao trabalho escravo contemporâneo no Brasil, tendo o país adotado algumas medidas sob fiscalização da CIDH desde então, esperamos que a Sentença no Caso Fazenda Brasil Verde vs. Brasil possa ser um novo marco.

Seria especialmente significativo que a Corte identificasse e sugerisse medidas de combate às causas estruturais do trabalho escravo contemporâneo, para que um novo paradigma e um novo diálogo possam ser instaurados na nossa insistente, porém fraca, história de enfrentamento ao trabalho escravo contemporâneo.

220 Audiência Pública Caso Trabalhadores da Fazenda Brasil Verde vs. Brasil. Parte 3. Min: 1hr38min57seg. Disponível em: <https://vimeo.com/156624613>. Acesso em: 16 nov. 2016. 


\section{CONCLUSÃO}

Este trabalho teve como principal objetivo analisar o enfrentamento ao trabalho escravo contemporâneo rural no Brasil, a partir de um grande marco, que foi a celebração do acordo de Solução Amistosa no Caso José Pereira, bem como destacar quais seriam os principais desafios a serem encarados diante da possibilidade de um novo marco: a iminente sentença da Corte IDH no Caso Fazenda Brasil Verde.

Iniciamos o primeiro capítulo traçando um panorama geral do SIDH, de modo a esclarecer a forma como o mesmo atua e pode atuar para propagar e proteger os Direitos Humanos nas Américas, em especial no que tange ao trabalho escravo contemporâneo no Brasil. No segundo capítulo, introduzimos o conceito internacionalmente adotado de trabalho escravo e analisamos brevemente o contexto em que está inserido o trabalho escravo rural no Brasil. Nesse sentido, pudemos entender as circunstâncias em que se inserem muitos trabalhadores rurais, inclusive o José Pereira, cujo caso foi levado à CIDH. Para finalizar esse capítulo, analisamos os fatos do caso e as cláusulas do acordo alcançado.

No terceiro capítulo, nosso objetivo foi elencar as medidas que foram adotadas pelo Brasil após esse acordo, e o fizemos por meio de relatórios internacionais. Concluímos que as medidas foram insuficientes para romper com as amarras arcaicas da escravidão, as quais se fazem fortemente presentes em diversos momentos. Essa conclusão foi confirmada pela análise feita na segunda parte do capítulo três, em que estudamos as principais ameaças ao incipiente processo de enfrentamento ao trabalho escravo contemporâneo rural no país. Foi possível notar, também, como o

próprio ordenamento jurídico acaba por legitimar, por sua suposta neutralidade, a manutenção de uma sociedade absorvida pelo escravismo, que luta para não reconhecer sua própria realidade. 
Diante disso, pudemos compreender a decisão da CIDH de submeter à Corte IDH outro caso de trabalho escravo rural contra o Brasil: o Caso Fazenda Brasil Verde, o qual foi examinado no quarto e último capítulo do trabalho. Os fatos desse caso são extensos e perduraram do ano 1988 ao ano 2000. Sentimos necessidade de descrevê-los, dando um especial enfoque às questões processuais a ele relacionadas, pois tal abordagem evidencia como o próprio sistema jurídico acabou legitimando um sistema político, social e econômico que não questiona suas raízes escravocratas. Seguimos a análise do caso verificando alguns dos principais argumentos levantados pelos representantes do Estado e das vítimas durante a audiência pública realizada na Costa Rica e suas expectativas quanto à iminente sentença da Corte.

Concluindo o último capítulo, tecemos nossos comentários e expressamos nossas próprias expectativas quanto à sentença. Em nossa opinião, a Corte IDH está diante de uma grande oportunidade de firmar sua jurisprudência acerca do trabalho escravo contemporâneo, que não se trata de um problema isolado do Brasil. Nesse sentido, esperamos que ela delimite o alcance do artigo $6^{\circ}$ da Convenção Americana, confirme seu entendimento acerca da responsabilização internacional do Estado pelo mesmo não ter cumprido com seus deveres de prevenção, repressão e investigação da submissão de diversos trabalhadores em condições análogas à escravidão.

Consideramos tratar-se de uma oportunidade especialmente relevante para a Corte identificar e recomendar medidas de combate às causas estruturais do trabalho escravo contemporâneo, para que um novo paradigma e um novo diálogo possam ser instaurados na nossa insistente, porém fraca, história de enfrentamento ao trabalho escravo contemporâneo.

Por fim, deixamos a boa notícia que a sentença no Caso Fazenda Brasil Verde vs. Brasil foi publicada após o término e entrega desse trabalho, na véspera de sua defesa perante a banca, no dia 15 de dezembro 
de $2016^{221}$. Por tal motivo, não foi possível abordá-la aqui, porém pudemos lê-la e tecer algumas considerações durante a defesa oral. Dentre essas considerações, podemos aqui mencionar algumas e analisar se as mesmas atenderam ou não às nossas expectativas.

No que diz respeito à competência em relação aos fatos, a Corte considerou que poderia analisar as questões processuais decorrentes da fiscalização realizada em 15 de março 2000 e as questões de mérito relacionadas às condições dos 85 trabalhadores resgatados na ocasião. Considerou que poderia analisar, também, as atuações realizadas no processo penal e na Ação Civil Pública com início em 1997 a respeito da fiscalização de 10 de março do mesmo ano.

A Corte declarou o Estado responsável pela violação ao artigo $6^{\circ}$ combinado com os artigos 1.1, 3, 5, 7, 11 e 22 da CADH em prejuízo dos 85 trabalhadores resgatados em 15 de março de 2000 na Fazenda Brasil Verde e, em especial, no que se refere às violações perpetradas contra Antônio Francisco da Silva, o artigo 19 foi combinado aos elencados acima.

Ademais, declarou a responsabilidade do Estado pela violação ao artigo 6.1 em relação com o artigo 1.1 da $\mathrm{CADH}$, produzida no marco de uma situação de discriminação estrutural histórica, em razão da posição econômica dos 85 trabalhadores.

Alegou, também, que o Estado é responsável por violar as garantias judiciais de devida diligência e de prazo razoável, previstas no artigo 8.1 combinado com o artigo 1.1 da $\mathrm{CADH}$ em prejuízo dos 43 trabalhadores encontrados durante a fiscalização de 23 de abril de 1997.

A Corte ainda declarou a responsabilidade do Estado pela violação do direito à proteção judicial, assegurado no artigo 25 da CADH em relação com os artigos 1.1 e 2 da mesma, em prejuízo: (i) dos 43 trabalhadores da Fazenda Brasil Verde encontrados em 23 de abril de 1997 e, (ii) dos 85

221 CORTE IDH. Caso Trabalhadores da Fazenda Brasil Verde vs. Brasil. Sentença de 20 de outubro de 2016. 
trabalhadores da Fazenda Brasil Verde encontrados em 15 de março de 2000. Além disso, em relação a Antônio Francisco da Silva essa violação ocorreu em relação ao artigo 19 da $\mathrm{CADH}$.

Por fim, a Corte não considerou o estado responsável pela violação aos direitos à personalidade jurídica, vida, integridade, liberdade pessoal, garantias e proteção judiciais, contemplados nos artigos 3, 4, 5, 7, 8 e 25 em relação com os artigos 1.1 e 19 da CADH em prejuízo de Luis Ferreira da Cruz e Iron Canuto da Silva e seus familiares, por ausência de indícios suficientes de que os mesmos tenham desaparecido em razão do trabalho na Fazenda Brasil Verde.

Em relação à conceituação de trabalho escravo e à delimitação do alcance do artigo $6^{\circ}$ da $\mathrm{CADH}$, a Corte atendeu integralmente às nossas expectativas. Ela abordou em detalhes o conceito, explicando e diferenciando os significados de trabalho escravo, trabalho forçado, servidão e tráfico de pessoas para exploração econômica.

A Corte afirmou, ainda, que o artigo $6^{\circ}$ entra no rol de direitos inderrogáveis e considerou a exploração de trabalho escravo como crime de lesa-humanidade, cuja proibição é norma de jus cogens.

Outra análise muito interessante feita pela Corte foi em relação à discriminação estrutural das pessoas aliciadas para o trabalho escravo, reconhecendo que nesse contexto se perpetuaram as violações ao artigo $6^{\circ}$. Afirmou que esse tipo de discriminação consiste em violação ao artigo 1.1 da CADH. Nesse sentido, a Corte discorreu, mesmo que de forma breve, sobre o assunto das raízes históricas, sociais e econômicas do trabalho escravo contemporâneo, responsabilizando o Estado por não ter conferido especial proteção a pessoas que ele sabia serem vulneráveis. Ou seja, o Estado não só deveria saber, como sabia da vulnerabilidade dessas pessoas e foi negligente. Destacou que a posição econômica da pessoa é uma das causas de discriminação proibidas pelo art. 1.1 CADH. Disse que os Estados são obrigados a adotar medidas positivas para mudar situações 
discriminatórias em suas sociedades em prejuízo de um grupo de pessoas. Isso implica o dever especial de proteção que o Estado deve exercer com respeito a práticas de terceiros sob sua tolerância ou aquiescência que mantenham e favoreçam situações discriminatórias.

A Corte também afirmou que o crime de exploração de trabalho escravo é imprescritível e determinou que o Brasil se adeque a esse entendimento, adotando as medidas legislativas necessárias. Nossa expectativa era a de que, de fato, a Corte se manifestasse nesse sentido, mas, conforme desenvolvido no capítulo 4 desse trabalho, consideramos pouco provável que o Brasil cumpra com essa determinação.

Em relação à determinação de reparações pela Corte na sentença, alguns aspectos não atenderam às nossas expectativas. Dentre eles, podemos mencionar algumas questões acerca das quais esperávamos que a Corte se posicionasse.

Acerca do projeto legislativo que visa a restringir o conceito de trabalho escravo, a Corte afirmou que não poderia intervir ou se pronunciar em relação ao processo legislativo interno do Estado. Já em relação à proporcionalidade da pena prevista no art. 149 do CP, a Corte apenas disse que acha que a pena tem que ser proporcional à gravidade do crime, mas que cabe ao Estado determinar os limites da pena.

Outra parte da sentença que ficou aquém de nossas expectativas foi a referente às Políticas Públicas, dentre as medidas de reparação. A Corte afirmou que não considera necessário recomendar políticas públicas adicionais pois considerou as existentes suficientes. Se limitou a alertar que elas deveriam continuar sendo implementadas e que não poderia haver qualquer retrocesso na matéria. Em nossa opinião a Corte foi muito complacente com o Estado.

Também concluímos, ao longo desse trabalho, que o Estado adotou muitas medidas, muitas delas citadas e analisadas por nós nesse trabalho, porém acreditamos que a Corte não precisava ter declarado que não era 
necessário o desenvolvimento de novas políticas públicas. Acreditamos que a Corte poderia, sim, ter reconhecido e elogiado os esforços do Estado e os resultados positivos por ele alcançados, mas também poderia ter incentivado o Estado a permanecer evoluindo no desenvolvimento e implementação de novos projetos e políticas.

Nossa expectativa era a de que a Corte se posicionasse e alertasse o Estado acerca de questões delicadas constatadas no momento atual, como a situação da Lista Suja, o enfraquecimento dos GEFM e a regulamentação da EC n. 81, que corre o risco de ter seu sentido esvaziado.

Apesar de algumas expectativas não terem sido alcançadas, nossa conclusão geral quanto à sentença foi bastante positiva. A partir desse novo marco, continuaremos analisando a situação de enfrentamento ao trabalho escravo. Esperamos que essa sentença sirva de parâmetro para novos casos que cheguem ao SIDH e que o Brasil aproveite essa oportunidade para "erradicar de vez essa vergonha".

Quando será que a "Casa-Grande \& Senzala” cederá lugar ao "outro Brasil que vem aí"?

\author{
“(...)Eu ouço as vozes \\ eu vejo as cores \\ eu sinto os passos \\ desse Brasil que vem ai'”.
}

(O outro Brasil que vem aí. Gilberto Freyre, $1926^{222}$ )

\footnotetext{
${ }^{222}$ FREYRE, Gilberto. Casa-grande \& Senzala. $48^{\mathrm{a}}$ ed. Recife: Global Editora, 2003.
} 


\section{REFERÊNCIAS BIBLIOGRÁFICAS}

AGÊNCIA BRASIL. OEA vai julgar responsabilidade do Brasil em caso de trabalho escravo. Publicado em 04.02.2016. Disponível em:

$<$ http://agenciabrasil.ebc.com.br/direitos-humanos/noticia/2016-02/oea-vaijulgar-responsabilidade-do-brasil-em-caso-de-trabalho>. Acesso em: 18 nov. 2016.

AGÊNCIA BRASIL. Brasil espera decisão favorável da OEA em julgamento sobre trabalho escravo. Publicado em 05.02.2016. Disponível em: <http://agenciabrasil.ebc.com.br/direitos-humanos/noticia/201602/brasil-espera-decisao-favoravel-da-oea-em-julgamento-sobre-trabalho>. Acesso em: 17 nov. 2016.

AGUIRRE, Carlos et al. La abolición de la esclavitud em hispanoamérica y Brasil. Nuevos aportes y debates historiográficos. p. 66. Fundación Ignacio Larramendi. Disponível em:

<http://www.larramendi.es/i18n/catalogo_imagenes/grupo.cmd?path=1000 211>. Acesso em: 24 out. 2016.

AUDI, Patrícia. Escravagismo Impune. O Globo, Opinião Consultiva, p. 7. Publicado em 22.05.2006. Disponível em:

$<$ https://www2.senado.leg.br/bdsf/bitstream/handle/id/400299/noticia.htm?s equence $=1>$. Acesso em: 03 out. 2016.

O GLOBO. Brasil será julgado por trabalho escravo: Corte Interamericana de Direitos Humanos analisa a responsabilidade do país. 18 de fevereiro de 2016. O GLOBO. Disponível em: <http://oglobo.globo.com/economia/brasil-sera-julgado-por-trabalhoescravo-18696839>. Acesso em: 15 nov. 2016.

BRASIL. Lei n. 10.706 de 25 de agosto 2003. Autoriza a União a conceder indenização a José Pereira. Disponível em:

<http://www.planalto.gov.br/ccivil_03/leis/2003/L10.706.htm>. Acesso em: 05 out. 2016.

BRASIL. Ministério do Trabalho. Manual de Combate ao Trabalho em Condições Análogas às de Escravo, 2011. 
BRASIL. Ministério do Trabalho. Plano Nacional para Erradicação do Trabalho Escravo. Disponível em:

<http://trabalho.gov.br/images/Documentos/trabalhoescravo/planonacional2 003portugues.pdf >. Acesso em: 02 nov. 2016.

BRASIL. Senado Federal. "Planos brasileiros de erradicação: história dos planos brasileiros de erradicação do trabalho escravo”. Jornal do Senado. Brasília, ano 2, no 7. Maio de 2011. Disponível em: $<$ https://www.senado.gov.br/noticias/Jornal/emdiscussao/trabalhoescravo/combate-ao-trabalho-escravo/planos-brasileiros-deerradicacao.aspx>. Acesso em: 03 nov. 2016.

BRASIL. Supremo Tribunal Federal. Disponível em: <http://www.stf.jus.br/portal/processo/verProcessoAndamento.asp>. Acesso em: 11 nov. 2016.

BRASIL. Supremo Tribunal Federal. Medida Cautelar na Ação Direta de Inconstitucionalidade n. 5209. Relator: Ministra Cármen Lúcia. Brasília, 23 de dezembro de 2014. DJE nº 22, divulgação em 2.2.2015.

CHAGAS, Daniel de Matos Sampaio. O Ministério do Trabalho e Emprego e os Subsídios para Defesa Judicial da União nas Ações Relativas ao Cadastro de Empregadores do Trabalho Escravo. In: Possibilidades Jurídicas de Combate à Escravidão Contemporânea, Brasília: Organização Internacional do Trabalho (OIT), 2007.

CIDH. Relatório No 95/03 sobre o caso 11.289. Solução Amistosa. José Pereira e Brasil. Publicado em 24 de outubro de 2003.

CIDH. Relatório n 169/11, Caso 12.066 Admissibilidade e Mérito: Fazenda Brasil Verde vs. Brasil. OEA/Ser/L/V/II.143. Doc. 53. 3 de novembro de 2011.

CIDH. Relatório sobre a situação dos direitos humanos no Brasil. Aprovado em 29.09.1997. Disponível em: <https://cidh.oas.org/countryrep/brazil-port/indice.htm>. Acesso em: 23 nov. 2016.

CIDH. Comunidades Cautivas: Situación del Pueblo indígena guaraní y formas contemporâneas de esclavitud en el Chaco de Bolivia. OEA/Ser.L/V/II. Doc 58. 24 diciembre 2009. Disponível em: 
<http://www.cidh.org/pdf\%20files/COMUNIDADES\%20CAUTIVAS.pd>. Acesso em: 11 set. 2016.

CORTE IDH. Caso Trabajadores de la Hacienda Brasil Verde vs. Brasil: Información del caso. Disponível em: <http://www.corteidh.or.cr/docs/tramite/trabajadores_de_la_hacienda_brasi 1_verde.pdf $>$. Acesso em: 10 set. 2016.

CORTE IDH. Caso Almonacid Arellano vs. Chile. Exceções Preliminares, Mérito, Reparações e Custas. Sentença de 26 de setembro de 2006. Parágrafo 110.

CORTE IDH. Caso de La Masacre de Pueblo Bello vs. Colombia. Sentença de 31 de janeiro de 2006. Parágrafos 111 e 123-126.

CORTE IDH. Caso Escher e outros vs. Brasil. Sentença de 6 de julho de 2009.

CORTE IDH. Caso Gomes Lund e outros ("Guerrilha do Araguaia) vs. Brasil. Sentença de 24 de novembro de 2010. Parágrafos 102-108. CORTE IDH. Caso Ríos y otros vs. Venezuela. Sentença de 28 de janeiro de 2009. Parágrafo 137.

CORTE IDH. Caso González y otras (Campo Algodonero) vs. México. Sentença de 16 de novembro de 2009. parágrafos 242 e 258.

CORTE IDH. Caso Massacre de Mapiripán vs. Colômbia. Sentença de 15 de setembro de 2005. Parágrafo 111;

CORTE IDH. Caso Massacres de Ituango vs. Colombia. Sentença de 1 de julho de 2006. Disponível em:

<http://www.corteidh.or.cr/docs/casos/articulos/seriec_148_esp.pdf>.

Acesso em: 23 nov. 2016.

CORTE IDH. Caso Massacres de Ituango vs. Colombia. Sentença de 1 jul. 2006. Parágrafo 160.

CORTE IDH. Caso Massacres do Rio Negro vs. Guatemala. Sentença de 4 de setembro de 2012. Disponível em: 
$\langle$ http://www.corteidh.or.cr/docs/casos/articulos/seriec_250_esp.pdf $>$. Acesso em: 23 nov. 2016.

CORTE IDH. Caso Paniangua Morales e outros ("Kombi Branca") vs. Guatemala. Sentença de 8 de março de 1998. Parágrao 91.

CORTE IDH. Caso Velásquez Rodríguez vs. Honduras. Sentença de 29 de julho de 1988. Parágrafos 166 e 176;

CORTE IDH. Interpretação da Declaração Americana dos Direitos e Deveres do Homem no Marco do Artículo 64 da Convenção Americana sobre Direitos Humanos. Opinião Consultiva OC10/89 de 14 de julho de 1989. Serie A No. 10, parágrafos 35-45. Disponível em: <http://www.corteidh.or.cr/docs/opiniones/seriea_10_esp1.pdf >. Acesso em: 09 set. 2016.

CORTE IDH. Otros Tratados objeto de La Función Consultiva de La Corte. (Art. 64 Convención Americana sobre Derechos Humanos). Opinião Consultiva OC-1/82 de 24 de setembro de 1982, p. 14.

REPÓRTER BRASIL. Escravo nem pensar!. Disponível em: <http://escravonempensar.org.br/sobre-o-projeto/quem-somos/>. Acesso em: 08 nov. 2016.

GARCIA, Gustavo Filipe Barbosa. Norma sobre empresa que usou escravos visa à concretização do trabalho decente. Conjur. Publicado em 05.06.2016. Disponível em: <http://www.conjur.com.br/2016-jun05/gustavo-garcia-norma-escravidao-melhora-condicoes-trabalho>. Acesso em: 23 nov. 2016.

CORTE IDH. Historia de la Corte IDH. Disponível em: <http://www.corteidh.or.cr/index.php/es/acerca-de/historia-de-la-corteidh〉. Acesso em: 12 set. 2016.

ETHOS. Pacto Internacional pela Erradicação do Trabalho Escravo. Disponivel em:

<https://www3.ethos.org.br/conteudo/projetos/apoiados/pacto-nacionalpela-erradicacao-do-trabalho-escravo/\#.WCEmXvorLIU>. Acesso em: 07 nov. 2016. 
FREYRE, Gilberto. Casa-grande \& Senzala. 48 ${ }^{\mathrm{a}}$ ed. Recife: Global Editora, 2003.

CIDH. Documento de submissão do Caso Fazenda Brasil Verde vs. Brasil à jurisdição da Corte, datado de 4 de março de 2015. Disponível em: <https://www.oas.org/es/cidh/decisiones/corte/2015/12066NdeResPT.pdf>. Acesso em: 15 nov. 2016.

MAZZUOLI, Valerio de Oliveira. Curso de Direito Internacional Público. $7^{\mathrm{a}}$ ed. São Paulo: Editora Revista dos Tribunais, 2013.

MENDES, Carlos. Grupo de fiscais do trabalho é atacado por pistoleiros do Pará. 20.05.2016. Estadão. Disponível em:

$<$ http://politica.estadao.com.br/noticias/geral,grupo-de-fiscais-do-trabalhoe-atacado-por-pistoleiros-no-para,10000052523>. Acesso em: 21 nov. 2016.

MINISTÉRIO DO TRABALHO E EMPREGO (MTE). Manual para combate ao Trabalho em condições análogas a de escravo. Brasília, 2011.

NAÇÕES UNIDAS NO BRASIL (ONUBR). Trabalho Escravo. Brasília, abril de 2016.

OIT. ORGANINZAÇÃO INTERNACIONAL DO TRABALHO. Trabalho Escravo no Brasil do Século XXI. $1^{\text {a }}$ ed., SAKAMOTO. Leonardo (Coord.). Brasil, 2006.

OIT. Combatendo o trabalho escravo contemporâneo: o exemplo do Brasil, 2010.

OIT. Relatório Global do Seguimento da Declaração da OIT sobre Princípios e Direitos Fundamentais no Trabalho. Uma Aliança Global Contra o Trabalho Forçado. Genebra: Secretaria Internacional do Trabalho, Conferência Internacional do Trabalho, 93ª Reunião, 2005.

INTERNATIONAL LABOUR ORGANIZATION. Forced Labour and Human Trafficking: Casebook of Court Decisions. A training manual for judges, prosecutors and legal practitioners. International Labour Office. Geneva: ILO, 2009. 96 p. 
PASQUALUCCI, Jo. The practice and procedure of the Inter-American Court on Human Rights. p. 80. In: PIOVESAN, Flávia. Direitos Humanos e Justiça Internacional. $3^{a}$ ed. São Paulo: Saraiva, 2012.

PIOVESAN, Flávia. Direitos Humanos e Justiça Internacional. $3^{\text {a }}$ ed. São Paulo: Saraiva, 2012.

PLASSAT, Xavier. Caso de trabalho escravo faz OEA pôr Brasil no banco dos réus: Governo brasileiro foi julgado por omissão no combate aos casos da fazenda Brasil Verde. 01 de março de 2016. Repórter Brasil. Disponível em: <http://reporterbrasil.org.br/2016/03/caso-de-trabalho-escravo-faz-oeapor-brasil-no-banco-dos-reus/>. Acesso em: 15 nov. 2016.

REPÓRTER BRASIL. Lista de Transparência traz 349 nomes flagrados por trabalho escravo. Publicado em 06.06.2016. Disponível em: $<$ http://reporterbrasil.org.br/2016/06/lista-de-transparencia-traz-349-nomesflagrados-por-trabalho-escravo/>. Acesso em: 11 nov. 2016.

REPÓRTER BRASIL. Zé Pereira, um sobrevivente. Entrevista. Publicada em 02.06.2004. Disponível em: <http://reporterbrasil.org.br/2004/06/zepereira-um-sobrevivente/>. Acesso em: 2 out. 2016.

SAKAMOTO, Leonardo. Disponível em: $<$ http://reporterbrasil.org.br/2016/05/no-ultimo-dia-governo-lanca-portariaque-recria-lista-suja-da-escravidao-2/>. Acesso em: 13 nov. 2016.

SAKAMOTO, Leonardo. Confisco de imóveis flagrados com escravos é aprovado pelo Congresso. Publicado em 27.05.2014. Disponível em: $<$ http://blogdosakamoto.blogosfera.uol.com.br/2014/05/27/confisco-deimoveis-flagrados-com-escravos-e-aprovpelo-congresso/>. Acesso em: 09 nov. 2016.

SAKAMOTO, Leonardo. No último dia, governo lança portaria que recria "lista suja" da escravidão. Publicado em 11.05.2016. Disponível em: <http://blogdosakamoto.blogosfera.uol.com.br/2016/05/11/no-ultimo-diagoverno-lanca-portaria-que-recria-lista-suja-da-escravidao/>. Acesso em: 23 nov. 2016.

SECRETARIA ESPECIAL DE DIREITOS HUMANOS. Comissão Nacional para a Erradicação do Trabalho Escravo. Disponível em: 
$<$ http://www.sdh.gov.br/assuntos/conatrae/programas/comissao-nacionalpara-a-erradicacao-do-trabalho-escravo>. Acesso em: 04 nov. 2016.

SANTOS, Cecília Macdowell Santos. Ativismo jurídico transnacional e o Estado: reflexões sobre os casos apresentados contra o Brasil na Comissão Interamericana de Direitos Humanos. SUR, Revista Internacional de Direitos Humanos. Vol. 4, nº 7. São Paulo. 2007.

SCHETTINI, Andrea Bandeira de Mello. Os Padrões Estabelecidos pela Corte Interamericana de Direitos Humanos sobre Liberdade de Expressão e a Análise do Caso Ríos e Outros vs. Venezuela. Rio de Janeiro. 2010. 70 p. Tese (Graduação em Direito) - Departamento de Direito da PUC-Rio.

SHAHINIAN, Gulnara. ONU. Human Rights Council. Report of the Special Rapporteur on contemporary forms of slavery, inclluding its causes and consequences, Gulnara Shahinian. Missio to Brazil. 30.08.2010.

SOARES, Marcela. Como Erradicar o Trabalho Escravo no Brasil? Notas a Propósito do Relatório da ONU. Brasiliana - Journal for Brazilian Studies. Vol. 2, n. 2 (Nov. 2013). ISSN 2245-4373.

TAVARES, Paulo Henrique da Silva. O Dever de Prevenção Estabelecido pela Corte Interamericana de Direitos Humanos. Rio de Janeiro. 2015. 100 p. Tese (Graduação em Direito) - Departamento de Direito da PUC-Rio.

VIANA, Marco Túlio. “Trabalho Escravo e 'Lista Suja': um modo original de remover uma mancha" In: Possibilidades Jurídicas de Combate à Escravidão Contemporânea, Brasília: Organização Internacional do Trabalho (OIT), 2007.

WROBLESKI, Stefano. Dez anos depois, cinco acusados pela Chacina de Unaí ainda não foram julgados. 28.01.2014. Repórter Brasil. Disponível em: <http://reporterbrasil.org.br/tags/chacina-de-unai/>. Acesso em: 21 nov. 2016. 